\title{
SURREALISM AND PHOTOGRAPHY IN 1930s JAPAN
}


$\Longrightarrow$ Taylor \& Francis Taylor \& Francis Group

http://taylorandfrancis.com 


\section{SURREALISM AND PHOTOGRAPHY IN 1930s JAPAN}

The Impossible Avant-Garde JELENA STOJKOVIĆ 
First published 2020 by Bloomsbury Academic

Published 2020 by Routledge

2 Park Square, Milton Park, Abingdon, Oxon OX14 4RN

605 Third Avenue, New York, NY 10017

Routledge is an imprint of the Taylor \& Francis Group, an informa business

Copyright $\odot$ Jelena Stojković, 2020

Jelena Stojković has asserted her right under the Copyright, Designs and

Patents Act, 1988, to be identified as Author of this work.

For legal purposes the Acknowledgements on $\mathrm{p} . \mathrm{x}$ constitute an extension of this copyright page.

Cover design by Graham Robert Ward

Cover image: HiraiTerushichi, Face, c.1940. Courtesy of Tokyo Photographic Art Museum,

(c) Atsuko Iwasaki

All rights reserved. No part of this book may be reprinted or reproduced or utilised in any form or by any electronic, mechanical, or other means, now known or hereafter invented, including photocopying and recording, or in any information storage or retrieval system, without permission in writing from the publishers.

Notice:

Product or corporate names may be trademarks or registered trademarks, and are used only for identification and explanation without intent to infringe.

A catalogue record for this book is available from the British Library.

A catalogue record for this book is available from the Library of Congress.

ISBN13: 978-1-7883-1405-3 (hbk)

Typeset by Integra Software Services Pvt. Ltd. 


\section{CONTENTS}

List of Illustrations vii

Acknowledgements $x$

Note on the Use of Japanese Language xii

Introduction 1

PART ONE 'NEW' PHOTOGRAPHY

(shinkō shashin) 11

1 Emergence 13

Artistic intentions 16

Beyond reality 21

Abandoning control 25

Professionals and amateurs 29

2 Photo-collages 37

Two-way mirrors 38

Constellation 46

Fragmentation 50

Overlaying, staging, re-photographing 54

PART TWO 'AVANT-GARDE' PHOTOGRAPHY (zen'ei shashin) 63

3 Images without texts 65

Criticism 67

Repetition 71

Representation 80

Printed matter 89 
4 Coded revolution 92

Photographs of objects 96

'Camera's automatism' 100

'Neo-Surrealism' 107

\section{Part Three 'PLASTIC' PHOTOGRAPHY}

(zōkei shashin) 115

\section{Materiality 117}

Abstraction 120

Paranoia-criticism 123

Scale and perspective 125

Photographic technology 134

\section{Locality 140}

Exchange 141

Traditional aesthetics 151

Everyday life 155

Disconnection 160

Conclusion 167

Selected Biographies 178

Selected Organizations 184

Notes 188

Bibliography 228

Index 250 


\section{ILLUSTRATIONS}

\section{Chapter 1}

1.1 Nakayama Iwata, Untitled, May 193218

1.2 Koishi Kiyoshi, Is There Something Funny?, January 193422

1.3 Ei-Kyū, 'For a Free Production of Photograms', August 193027

1.4 Ei-Kyū, from The Reason for Sleep, 193629

1.5 Matsubara Jūzō, Untitled, 1934-1935 31

1.6 Matusbara Jūzō, Untitled, 193632

1.7 Matsubara Jūzō, Liberated Fantasy, 1936-1937 33

\section{Chapter 2}

2.1 Imai Shigeru, A Cheerful Traveller (1936), October 193840

2.2 Yamanaka Chirū, Il y a un océan facile, 193741

2.3 Yamanaka Chirū, Collage, June 193744

2.4 Yamamoto Kansuke, Collage, 193850

2.5 Ei-Kyū, Real, 193751

2.6 Hanawa Gingo, Complex Imagination, 193854

2.7 Nagata Isshū, Nerval, Dream and Life, July 193857

2.8 Nagata Isshū, Untitled, 1930-1939 58

2.9 Nagata Isshū, Fire Mountain, 193959

2.10 Abe Yoshifumi, A Shot of Mount Yake, July 194060

\section{Chapter 3}

3.1 Hanawa Gingo, Light and Dark Flower and Yasui Nakaji, Butterfly, September 193872

3.2 Hirai Terushichi, Blue Sky, September 193875 
3.3 Yasui Nakaji, Composition: Gyroscope, 193876

3.4 Hirai Terushichi, Fantasy of the Moon, 193876

3.5 Hirai Terushichi, Altar, July 193879

3.6 Ueda Bizan, Delighted, 194081

3.7 Hirai Terushichi, Face, 194083

3.8 Hanawa Gingo, 'Dream of Spring in Broad Daylight', July 193885

3.9 Hanawa Gingo, 'Dream of Spring in Broad Daylight', July 193886

3.10 Ikemiya Seijirō, Shadow, October 193888

\section{Chapter 4}

4.1 Koishi Kiyoshi, 'Record of a Camera Trip to Kamikōchi', October 193898

4.2 Sakata Minoru, Edible, Animal Mud, February 1939101

4.3 Shimozato Yoshio, Two Dormant Volcanoes, February 1939103

4.4 Sakata Minoru, Four and Shimozato Yoshio, A Balloon Giving Birth June 1939105

4.5 Shimozato Yoshio, from Mesemu zoku: Chōgenjitsushugi shashinshū, 1-10, 1940108

4.6 Various artists, edited by Shimozato Yoshio, from Mesemu zoku: Chōgenjitsushugi shashinshū, A-J, 1940109

\section{Chapter 5}

5.1 Abe Yoshifumi, Working at Night, 1938126

5.2 Abe Yoshifumi, Flow, February 1939127

5.3 Shimozato Yoshio, The Ninth Continent, April 1939128

$\mathbf{5 . 4}$ Imai Shigeru, Still Life, August 1939129

5.5 Takahashi Wataru, Spirit of the Sea, June 1938131

5.6 Takahashi Wataru, ‘__ ', June 1939133

5.7 Yamanaka Chirū, 'Sakata Minoru's Artwork', January 1939135

5.8 Sakata Minoru, Parage, 1939137

5.9 Sakata Minoru, Sphere, 1939138 


\section{Chapter 6}

6.1 Abe Yoshifumi, Two Poses, March 1939143

6.2 Abe Yoshifumi, Two Landscapes, February 1940144

6.3 Hasegawa Saburō, Sliding Door, September 1939148

6.4 Konomi Giichirō, Untitled, October 1939149

6.5 Konomi Giichirō, White Door, January 1940151

6.6 Yamanaka Chirū, 'Occasional Thoughts on Plastic Photography', July 1940152

6.7 Sakata Minoru, Zōkei shashin, 1941158

6.8 Shimozato Yoshio, Garments, Zōkei shashin, 1941159

6.9 Tajima Tsugio, Dishcloth Embroidery and Piles of Folded Newspapers, Zōkei shashin, 1941160

6.10a Yamamoto Kansuke, Birdcage at a Buddhist Temple, 1940162

6.10b Yamamoto Kansuke, Untitled, 1940162

6.11 Yamamoto Kansuke, Landscape, 1940162 


\section{ACKNOWLEDGEMENTS}

I first encountered the material discussed in this book during my MA in Art History at SOAS, University of London, over a visit to the British Museum's Japanese Galleries organized by Dr John Carpenter, my mentor at the time. I continued to engage with it during my doctoral programme of studies at the University of Westminster, under the supervision of Dr Neil Matheson and Professor David Bate, and during my Japan Foundation Fellowship Programme at the University of Tokyo, supported by Professor Hoshino Moriyuki. After consulting several archives and collections in the UK and Japan, I completed my thesis, 'Out of Sight: Surrealism and Photography in 1930s Japan', in 2013. Some of its elements were published as book chapters in Minor Photography: Connecting Deleuze and Guattari to Photography Theory (2012) and Object Fantasies: Experience and Creation (2018). I have since revised and rewritten my research for the adapted and expanded context of the book.

I would like to thank the Daiwa Anglo-Japanese Foundation for supporting the completion of this project, the Great Britain Sasakawa Foundation and the Arts University Bournemouth for allocating funds towards its production and all the institutions and individuals who helped me to locate high-resolution images and clear them of copyright, especially Fujimura Satomi from the Tokyo Photographic Art Museum, Takeba Jō from the Nagoya City Art Museum, Kasai Horiyuki from the Yamanaka Chirū Archive at Keio Hiyoshi Library, Abe Yoshimori, Asazuma Shoichi, Iwasaki Atsuko, Kurosawa Yoshiteru, Sakata Takashi, Shimozato Masao, Tajima Shōzō, Ueda Kyozan, Yamamoto Toshio and Yamanaka Keiichi. I would also like to thank Baillie Card, Lisa Goodrum, Louise Baird-Smith and Alexander Highfield for overseeing the long process of the book's publication, Professor Elza Adamowicz and Professor Krzysztof Fijalkowski for their kind peer reviews and Miwako Hayashi Bitmead for invaluable improvements to my translations and readings of names and titles of sources and artworks in Japanese.

I have been teaching contextual studies for fine art and design together with history and theory of photography since my PhD, and I would like to thank Beverley Carruthens, Duncan Wooldridge, Dr Wiebke Leister, Caryn Simonson, Janice McLaren and David Hazel for entrusting me with those roles and all my colleagues and students for their insights and enthusiasm. I am grateful 
for the generosity of my friends: Marko Jobst, Dragana Gavrilović, Sanja Tripković, Takahashi Yoshiko, Julian Ross, Hirasawa Gō, Ruth Novaczek, Başak Ertür, Alisa Lebov, Anton Katz, Marijana Cvetković, Tatjana Gostiljac, Jelena Sokić, Ivonne Santoyo Orozco, Ross Exo Adams, Lucie Mercier, Jonathan Roux, Paulina Lenoir Guajardo, Bahbak Hashemi-Nezhad, Catarina Cubelo, Olivier Rodriguez, Marie Roux, Margareta Kern, Marcus Kern, Flora Pitrolo, Robert Jack, Ricardo Matos Cabo, Karen Di Franco, Mohammad Namazi, Federica Chiocchetti, Ignacio Acosta, Ayesha Hameed, Regine Ehleiter, Christian Berger, Dan Abbe, Persilia Caton, Joseph Kendra, Karen McQuaid, Jonathan Kemp, Joana Rafael, Andrea Pavoni, Habib Lešević, Manca Bajec, Gregor Bulc, Iskra Andreeva, Emma Bennett, Killian Fox, Noah Angel, Deniz Johns, Martin Zeilinger, Lizzie Homersham, Nikolaus Perneczky, Frances Ross, Tasaka Hiroko, Uesaki Sen, and Matsui Shigeru.

I grew up in Belgrade and studied Arabic and Japanese before moving to London. I would not be where I am without my family: my grandparents Ruža, Živan, Draga and Nikola, my parents Mileva and Dragiša, my sisters Marija and Snežana, as well as Mirko, Anđela, Mimi and Miloš.

Danilo, you are my book. 


\section{NOTE ON THE USE OF JAPANESE LANGUAGE}

For the use of Japanese language in this book, I applied the modified Hepburn system of romanization, including the macrons. I refer to Japanese names with the last name followed by the first name. All translations are my own, unless indicated otherwise. 


\section{INTRODUCTION}

La Peinture surréaliste, the first exhibition of Surrealist painting, opened at midnight on 13 November 1925. The crowds flooded the Galerie Pierre to see nineteen paintings by Hans Arp, Giorgio de Chirico, Max Ernst, Paul Klee, André Masson, Joan Miró, Pablo Picasso, Man Ray and Pierre Roy. ${ }^{1}$ The exhibition catalogue, put together by André Breton and Robert Desnos so as to include one photographic reproduction of each artist's artwork (except for Roy), accompanied the experience of viewing the show, which was the first in a series of sensationalist events that surrounded the public presentations of Surrealist visual arts in the following years. The art critic Moriguchi Tari and the painter Fukuzawa Ichirō went together to view the show before it closed on 25 November. Moriguchi brought the catalogue back with him to Japan and used the reproductions in an article that he wrote about modernist painting in 1928. In this article, however, he did not identify the artists as Surrealist and made no reference to Surrealism. ${ }^{2}$

Although the route through which the information about this historic exhibition reached Japan might have been unconventional, Moriguchi's text was not the first instance in which reproductions of Surrealist painting were seen in the country, as they were circulated at least through subscriptions to such art magazines as Cahiers d'art. It was Le Surréalisme et la peinture (1928) that made a definitive impact on Japanese painters interested in Surrealism, the very size of the volume $(24 \mathrm{~cm} \times 19 \mathrm{~cm})$ and the abundance of illustrations assuring an impressive viewing experience for that time. ${ }^{3} \mathrm{~A}$ translation of Breton's text into Japanese was published in June 1930 accompanied with fifty out of seventyseven images from the original volume. ${ }^{4}$ By then, Japanese painters had already started materializing an interest in Surrealism. For instance, Abe Kongō, Koga Harue and Togō Seiji exhibited Surrealist artworks at the sixteenth exhibition of the Second Division Society (Nikakai) in 1929, receiving mixed reviews in the January 1930 issue of Atorie, the first magazine issue dedicated to Surrealist visual art in Japan. ${ }^{5}$ It thus appears that Surrealist painting found a fertile ground in Japan soon after it was first exhibited in France. However, it seems to have done so without an explicit and singular grounding in Surrealist criticism or action. Rather, the first Surrealist paintings in Japan were seen in an annual 
show of an independent artistic collective, disconnected from Surrealism similar to Moriguchi's text.

Literary Surrealism preceded the practice of Surrealist painting in Japan by several years. Nishiwaki Junzaburō formed the first literary Surrealist group in the country, upon his appointment as a lecturer in English literature at the Keio University in 1926, following his studies at Oxford. ${ }^{6}$ The 'Keio group' - largely consisting of his students, the most prominent of which was the poet Takiguchi Shūzō - was not the only channel through which the meanings and significance of literary Surrealism were probed in Japan in the 1920s, as it was already finding its way into the country via different routes, earlier in time. The very word for Surrealism in Japanese, chōgenjitsushugi, was coined by an anarchist poet Muramatsu Masatoshi and appeared for the first time in 1925, simultaneous with a number of translations of Surrealist poetry. ${ }^{7}$ By the turn of the decade, a number of Surrealist texts were published in literary magazines, including Kitagawa Fuyuhiko's translation of the Manifeste du surréalisme (1924) that appeared in 1929 in the Shi to shiron magazine. By then, Koga, Nishiwaki and Takiguchi were recognized as harbingers of the movement's increasing influence in the country. ${ }^{8}$ However, at the same time, Surrealism also encountered criticism in Japan and was reproached to some extent for its reliance on translations as well as for its alleged elitism. ${ }^{9}$

Surrealism emerged as a literary movement in 1920s Paris after several years of collective activities of an early Surrealist group. Famously, Breton articulated it 'once and for all' in the Manifeste as 'psychic automatism in its pure state, by which one proposes to express - verbally, by means of the written word, or in any other manner the actual functioning of thought'. ${ }^{10}$ In this text, which coincided with the official forming of the Surrealist group in France, he proposes that Surrealism is a means for revolutionizing and liberating the mind, strained by the boundaries of logic and convention, which is to be achieved by a complete suspension of conscious control over its working. As a methodology aimed at opening the mind up to a different form of reality, one that acknowledges the space of dreams and aims at making them functional in the waking state, it was greatly indebted to Sigmund Freud's The Interpretation of Dreams (1900). However, as Roger Shattuck notes in the introduction to Maurice Nadeau's influential History of Surrealism (1944), any presumption about Surrealism beyond the general consensus that it refers to 'literary-artistic activity that cantered in Paris' quickly falls to pieces. ${ }^{11}$ Even the relationship to painting in a group initially consisting of poets was heatedly debated in the early days of the movement: given the specifications of automatism the very idea of Surrealist painting was considered unorthodox and this tension was among the chief reasons for the publication of Le Surréalisme et la peinture.

If some agreement were to be established about the nature of Surrealism, it would undeniably concern its group logic. ${ }^{12}$ Collective activity was its consistent 
and distinctive feature and was manifesting in different formats, ranging from games to publications and exhibitions. As Krzysztof Fijalkowski defines it, it has been 'the sine qua non for the elaboration of a Surrealist thought and culture, in a real sense authenticating, guaranteeing and moulding their very possibility'. ${ }^{13}$ In terms of Japan, what the brief overview above tells us is that the knowledge of Surrealism was arriving through varied channels and that it was engendering significant responses in literary and artistic circles. However, different practices such as Surrealist literature and painting developed mostly independently from each other and outside of a single, unified group and this fact - that there was no 'centre' to anchor Surrealism in Japan - is an essential quality of the movement's existence in the country. Within Surrealism's international orbit, forming concurrently and in direct relationship to the establishment of the French group, this feature was not exclusive and the well-known examples include at least Belgium and England. However, the fragmentation of literary Surrealism or the seemingly independent emergence of Surrealist painting needs to be viewed as a symptom rather than a cause of the inability to form a single group in Japan, where the enactment of the Peace Preservation Law (Chian ijihō) in 1925 proclaimed any organized opposition to national policy illegal. ${ }^{14}$ The governmental body in charge of executing this legislation was the Special Higher Police (Tokubetsu kōtō keisatsu), originally established in 1911 and sometimes referred to as the 'thought police' (shisō keisatsu), which systematically suppressed the Communist Party as well as anarchist or proletarian art groups. ${ }^{15}$

With a group of devoted supporters in France and the constant international expansion, Surrealism was gaining a high critical acclaim during the 1920 s but was also subject to various reproves and went through significant transformations. Most notably, these involved a number of attempts to establish links with the Communist Party under another prominent course of the Surrealist action: that of political commitment. Frustration caused by the inability to agree on the best-suitable means of political engagement resulted in a split within the French group and the 'Aragon affair' of 1929, caused by different positions towards the Communist Party taken up by Louis Aragon and Breton in the following two years. These events formed a background for the publication of Breton's Second manifeste du surréalisme in 1929, a 'reminder of principles' that marked the French group's taking of a separate, independent route from the party politics. ${ }^{16} \mathrm{~A}$ large part of this text is dedicated to discrediting most of the people who comprised Breton's immediate circle during the 1920s, such as Antonin Artaud, Philippe Soupault and Masson as well as Georges Bataille. Entering the 1930s Surrealism was determined by a course of 'total revolt', refreshed by new members such as Salvador Dalí and refocused on the problems of the Surrealist object. $^{17}$

In Japan, the Marxist left and the associated proletarian art movement were outlawed by 1934, with surveillance extending to Surrealist practices. Flourishing 
in the liberal climate of the 1920s, proletarian art came under increased pressure at the turn of the decade, as its activities were not only advocating worker strikes and political protests but were also starting to grow into a militant revolutionary front. ${ }^{18}$ Perceived as a challenge to the imperial power, Communism was systematically purged, together with all related organizations, by means of constant arrests in the 1920s. As this suppression was the primary if not the sole function of the Peace Preservation Law, the arrests became even more regular in the 1930s. ${ }^{19}$ In such a climate, Surrealism was understood as a 'cultural mission' of Communism ever since the publication of the Second manifeste. ${ }^{20}$ For instance, a 1931 definition of Surrealism within an annual governmental report reads:

[Surrealism] aims to liberate the human mind by overcoming various inconsistencies in human psychology. It claims that the psychological phenomena cannot exist without a relation to the realms of material, that the psychological inconsistencies are reflections of inconsistencies of capitalist society and tyranny ... and that the overcoming of the psychological inconsistencies must be conducted in tandem with the overcoming of socioeconomic inconsistencies as proclaimed by Marx. ${ }^{21}$

Despite many differences between proletarian art and Surrealism - as radical politics was the chief interest of the former while radical art was the main focus of the latter - the inability to form a singular group was conditioned by the shift of political climate in the later part of the 1920s, resulting in a distinct idiosyncrasy of Japanese Surrealism. Namely, although it nominally functioned within the movement's international framework, Surrealism in Japan operated as a dispersed network and its political goals were never singularly and straightforwardly formulated. This was an important reason why Surrealist painting and other visual arts such as photography were mostly practised independently from each other.

In other words, Surrealist photography in 1930s Japan, only emerging at the beginning of the decade, is fundamentally defined by impossibility or, as it were, several impossibilities. First of all, there was no singular Surrealist group to foster it and any public proclamation of a support for or an alliance with Surrealism could lead to surveillance or prosecution. To an extent, this situation mirrors a wider problem of authenticating historical avant-gardes in Japan, which were questioned on many occasions just like Surrealism was. ${ }^{22}$ As the notion of avant-garde is mostly understood from a Eurocentric point of view, its very existence in Japan could be considered as another impossibility to account for. ${ }^{23}$ This discourse - based on seminal postwar studies by such scholars as Matei Câlinescu and Peter Bürger, both following Renato Poggioli's Theory of the Avant-Garde (1962) - has long since been proved narrow and culturally biased. ${ }^{24}$ 
For instance, on the occasion of the Pompidou Centre's exhibition Japon des Avant Gardes 1910-1970 (1987), art historian Takashina Shüji demanded a more complex understanding of the practice in Japan, claiming that 'the history of avant-garde movements in Japan since approximately 1910 cannot be seen as a set of distant, more or less late and sometimes unnatural echoes of different artistic currents in the European countries'. ${ }^{25}$ Such demands have had an impact on the historical narrative of literary Surrealism in Japan, as it is recognized by now that it did not only mirror or mimic the systems of values and social formations imported from abroad but had its own unique position within the country's modernity. ${ }^{26}$

However, Japan occupies a specific place within the processes of cultural diversification of this discourse, acutely pertaining to avant-garde practice during the 1930s. As Eiji Oguma notes, situating Japan within the framework of Orientalism - in which the representation of the East is created by the West is problematic as Japan was subjected to the orientalizing gaze of the West while concurrently occupying and colonizing various countries in Asia. ${ }^{27}$ Such a context is relevant to the apprehension of the Japanese avant-garde in general as well as to the conditions of Japanese Surrealism during the 1930s in particular. Whereas the avant-garde groups in the 1920s such as Mavo had a direct relationship with revolutionary politics and were operating in parallel to the proletarian art movement, exercising any form of dissent by Surrealists during the 1930s was made impossible. This situation forces every discussion of Surrealism in 1930s Japan to take into consideration the complex dynamics of the time while acknowledging the fact that it enabled a crucial link between the prewar (senzen) and postwar (sengo) avant-gardes. For Surrealist photography, this link is also important considering that women photographers only started to adopt more active and visible roles in avant-garde circles in Japan after the war. ${ }^{28}$ Against such a background, one last impossibility that needs to be recognized is what we might regard as its underside or how impossible the avant-garde in Japan was to contain, dismiss and extinguish during the politically turbulent decade between the Manchurian Incident of 1931 and the outset of the Pacific War in 1941.

In the Manifeste, Breton situates the Surrealist image with regard to a definition offered by a French poet, Pierre Reverdy, as 'a pure creation of the mind' that 'cannot be born from a comparison but from a juxtaposition of two more or less distant realities'. ${ }^{29}$ Such a definition of the Surrealist image, insisting on the intertwining between a perceived, outer reality and an unconscious, inner state of mind, also celebrates the Surrealists' admiration for another French poet: Isidore Ducasse, aka Comte de Lautréamont. His phrase from Les chants de Maldoror (1868-1869) that describes a 'fortuitous encounter upon a dissecting table of 
a sewing machine and an umbrella' formed a base for Surrealist aesthetics, grounded in the search for chance encounters that would set free any rational measure or code imposed on the mind. ${ }^{30}$ Breton expressed his enthusiasm for the potential of photography to deliver such an image many times and as early as in 1920. ${ }^{31}$ Dalí advanced this enthusiasm further, positioning photography directly in relation to Reverdy's definition and discovering that it offered an opportunity to experiment with his paranoiac-critical method. ${ }^{32}$ Photographs were prominently featured in all of the principal Surrealist magazines as well as in Breton's novels. As a form of the Surrealist image, they share the same goal of disclosing the limited properties of conscious understanding and representation of reality, taking advantage of their special status as both indexical and iconic signs. ${ }^{33}$ However, a considerable lack of systematic theoretical investigation of the medium by Surrealists themselves, or the somewhat unclear position of photographers within Surrealist circles, as lan Walker notes, makes any conclusive writing on the subject difficult. ${ }^{34}$ Although photography is immanent to the discussion of Surrealist painting, at least through Breton's inclusion of Man Ray into Le Surréalisme et la peinture, the ontological question of Surrealist photography, or what it might stand for, has never been answered conclusively and is still a relevant one.

Early attempts at formulating a scholarship around the Surrealist use of photography in the 1980s, such as Édouard Jaguer's, indicated how the medium had opened new visual realms as a Surrealist practice by 'showing what the eye doesn't see' and by 'showing what the eye does see but differently'. ${ }^{35}$ Whereas such a relationship between Surrealism and photography grounded in the medium's nature as a quintessential means of modernist visual representation remains unquestioned, other studies at the time made attempts to either redefine Surrealism in view of photography or situate photography within the history of Surrealism. ${ }^{36}$ Susan Sontag thus describes photography as immanently Surrealist in character in On Photography (1977), whereas Rosalind Krauss establishes the photographic image in the centre of Surrealist action. ${ }^{37}$ Krauss's curatorial project L'Amour fou: Photography and Surrealism, undertaken with Dawn Ades and Jane Livingston and seen in New York, Paris and London in 1985 and 1986, provided the vocabulary with which Surrealist photography could be critically addressed. The later studies in the area probed different approaches to it, in terms of a wider sociopolitical relevance and via documentary photographic practices, in view of individual practitioners as well as Surrealism's global outreach. ${ }^{38}$

Within this scholarship, Jaguer recognized Japanese artists as important and included Ei-Kyū and Imai Shigeru in his study. ${ }^{39}$ This effort was lost to L'Amour fou, in which Krauss and Livingston made clear how they limited themselves to Surrealism's manifestations in Belgium, England, France and Germany. ${ }^{40}$ A more recent exhibition, La Subversion des images: surréalisme, photographie, film (2009-2010), which travelled between Paris, Winterthur and Madrid, signalled 
a significant evolution in the field, not only opening up the scope of analysis of photography's role within Surrealism to a wider circle of friends, dissidents and rivals related to the core Surrealist group gathered around Breton but also integrating international practices as a relevant feature. ${ }^{41}$ The exhibition included a photo-collage by Yamanaka Chirū, a Surrealist poet, critic and translator from Japan whose production of visual material was previously not that well known. While such inclusion indicates a return to the route previously paved by Jaguer, it points at a significant gap in the existing scholarship. As the catalogue of the exhibition does not offer much detail about the image or the artist, it evidences how Surrealist photography in Japan has been significantly under-represented in the history of Surrealism. This situation can be best observed in those cases when the existence of literary Surrealism or Surrealist painting in the country is acknowledged without a reflection on the practice of photography, as in the case of Gérard Durozoi's History of the Surrealist Movement (1997). ${ }^{42}$ In addition, it also ascertains how the same condition prevails in Japan as well, as the image was mostly unknown in the country prior to its inclusion in the show. ${ }^{43}$

The knowledge about Surrealist photography in 1930s Japan has been completely disregarded in photographic histories and reduced to sporadic mentions and elusive comments that are regularly featured in different volumes but scarcely reach beyond individual artists or singular works. ${ }^{44}$ This approach also dominates the field of modernist or so-called prewar Japanese photography. Although it might be considered a general issue entailed with the archiving and collecting of original prints from the period, Surrealist photographs are mostly identified individually and within existing modernist categories, such as avantgarde, or subsumed under a preference for a particular style..$^{45}$ Even though prominent photographers from the period who are known for their individual interests in Surrealism such as Nakayama Iwata, Ei-Kyū and Yasui Nakaji had substantial retrospective exhibitions in Japan since 2000, they did not initiate any coherent discussion in terms of their relationship with the movement. ${ }^{46}$ Finally, photography has been equally disregarded within the international academic community researching Surrealism in Japan until fairly recently. ${ }^{47}$ John Solt's efforts, leading up to an exhibition of Yamamoto Kansuke's photographs at the Tokyo Station Gallery in 2001, are unprecedented in terms of bringing to the fore the level of achievement of Surrealist photography in Japan and resulted in a continuous interest in the work of this artist, albeit without much regard for the versatility and richness of the field. ${ }^{48}$

This book's focus on Surrealist photography in 1930s Japan, therefore, offers a unique opportunity to gain a better understanding of this practice in the movement's global context as well as to simultaneously address the partial knowledge of Surrealism's existence in the country. An important point of departure in the pursuit of this goal is Nihon no shürurearisumu 1925-1945 (Japanese Surrealism 1925-1945), a pioneering exhibition mounted at the 
Nagoya City Art Museum in 1990 that made clear to what extent Surrealism was practised in Japan among varied artists in the period. A section dedicated to photography in the accompanying catalogue includes a number of primary sources and provides an overview of the chief outlets and individuals. ${ }^{49}$ The project was followed up by the publication of Korekushon Nihon shürurearisumu (Collection of Surrealism in Japan) in fifteen volumes between 1999 and 2001.50 This collection compiles primary sources published during the 1920s and 1930s, mostly in literary and art magazines, dividing them according to subjects and individuals of importance to the movement in Japan. These include volumes on criticism in poetry and visual arts, writings by the chief poets, critics and visual artists, a separate tome on key Surrealist publications and surveys of various important individuals working across different media. The collection tackles the previously noted problems with limited archival access to primary sources in Japanese on an unparalleled scale and it is gradually expanding the knowledge of Surrealist photography in 1930s Japan. ${ }^{51}$ A volume compiled on the subject of photographic criticism by the Nagoya City Art Museum's curator Takeba Jō informs this book on a significant scale.

As I believe that this practice can only be fully grasped within the original context in which it appeared, I often combine a close reading of different primary and secondary sources in Japanese with simultaneous research of the archival material of the time (photography magazine collections and correspondences). In my selection of reproduced works I balance out the prioritizing of previously little discussed photographs with in-depth readings of several important and already well-known images. I divide the text into three parts, each comprising two chapters, according to the chief critical terms relevant to the practice: 'new', 'avant-garde' and 'plastic' photography. These particular discursive rubrics are envisaged as methodological tools that enable a comprehensive mapping of Surrealist photography in 1930s Japan and are described in detail in separate sections vis-à-vis the critical positions relevant to the history and theory of art and photography in the country. Rather than following a strict chronological logic, separate chapters are tentatively related to the major events of importance to the topic and are conceived as layers of the narrative. They are addressing individual but always interconnected issues, most important of which is the nature of Surrealist photography in Japan.

In the section on 'new' photography (shinkō shashin), I discuss the difficulty that photography's status in 1930s Japan as a yet to be fully recognized form of artistic practice imposed on Surrealist photography. Flourishing in the aftermath of the touring Film und Foto (1931) and in the wake of the Manchurian Incident (1931), 'new' photography is a relevant context for Surrealist photography in Japan as a split within this practice to professionals and amateurs fostered a prominent channel for its emergence. Considering that Surrealist photography was practised in a constellation of different individuals, artistic and photographic 
outlets, especially after the Exposition de la confédération des artistes d'avantgarde, Paris-Tokio (1932), I also question the extent to which group dynamic was relevant to Surrealism in Japan despite its essentially decentred and fragmented nature. In order to do so, I dedicate a chapter to photo-collages, indicating some of the prominent conceptual issues and photographic methods driving their parallel production in the mostly separate photography and art 'worlds'.

The following two chapters focus on 'avant-garde' photography (zen'ei shashin), flourishing in Japan during 1937 and 1938 in the aftermath of a seminal exhibition of international Surrealism, opening only a month before the outbreak of the Second Sino-Japanese War in July 1937. I show how Surrealist photographers and critics around the country generated a unique theoretical discussion about the nature of their practice within this context, in relation to such notions as the everyday and displacement, or vis-à-vis abstraction. I describe in detail how photographers in Osaka developed specific approaches to the Surrealist object - Surrealism's predominant preoccupation in the 1930s - and I unpack the relationship between Surrealist photography and politics by focusing on collaborative projects in Tokyo and Nagoya that sought the ways to engage the viewer in their attempts to offer alternatives to the increasingly censored and ideologically loaded visual culture in this period.

Finally, I identify the problems arising from the means through which Surrealist photography negotiated its public presence in the years leading up to the Pacific War under the umbrella of 'plastic' photography (zōkei shashin). The two chapters comprising this part address materiality and locality as important notions to this type of practice, which I perceive as a means enabling the institutional affirmation of the artistic aspirations of Surrealist photographers as well as a relevant instrument allowing the continuation of their work even within the precarious position that they occupied in Japan during 1939 and 1940. Although this discourse was mobilized in an attempt to uphold avant-garde's autonomy from state politics, it signalled the final stage of oppression of the cultural field during the 1930s.

In addition, I partially reframe the book's chief findings in the postwar period in the Conclusion, confirming the importance of Surrealist photography in the 1930s to the appropriate understanding of not only Surrealism but also the lineage of twentieth-century avant-garde art in Japan. 


\section{NOTES}

\section{Introduction}

1 Gérard Durozoi, History of the Surrealist Movement, translated by Alison Anderson (Chicago: University of Chicago Press, 2009), 121.

2 Hayami Yutaka, Shururearisumu no kaiga to Nihon: Imēji no juyō to sōzō [Surrealist Painting and Japan: Image Reception and Creation] (Tokyo: Nihon Hōsō Shuppan Kyōkai, 2009), 19-22.

3 Ibid., 30.

4 Takiguchi Shūzō (trans.), 'Chōgenjitsushugi to kaiga (Andore Buruton)' [Surrealism and Painting (André Breton)], in Korekushon Takiguchi Shüzō 11, Senzen senchū hen 1: 1926-1936 [Collection Takiguchi Shūzō 11, Prewar and War Period 1, 1926-1936], ed. Takiguchi Shūzō, Ōoka Makoto et al. (Tokyo: Misuzu Shobō, 1991).

5 Atorie (editorial), 'Chōgenjitsushugi hihan' [Criticising Surrealism], in Korekushon Nihon shürurearisumu 15: Shürurearisumu kihon shiryō shūsei [Collection of Surrealism in Japan 15: Surrealism, Collection of Fundamental Documents], ed. Wada Hirofumi (Tokyo: Hon no Tomosha, 2001).

6 Hosea Hirata, The Poetry and Poetics of Nishiwaki Junzaburō: Modernism in Translation (Princeton, NJ: Princeton University Press, 1993), xxii-xxiv.

7 Muramatsu Masatoshi, 'Genjitsushugi to chōgenjitsushugi' [Reality and Surreality], in Korekushon Nihon shūrurearisumu 1: Shürurearisumu no shi to hihyō [Collection of Surrealism in Japan 1: Surrealist Poetry and Criticism], ed. Wada Hirofumi (Tokyo: Hon no Tomosha, 2000), 3-7. Nagoya-shi Bijutsukan (ed.), Nihon no shūrurearisumu: 1925-1945 [Surrealism in Japan: 1925-1945], exh. cat. (Nagoya: Nihon no Shūrurearisumuten Jikkō linkai, 1990), 18.

8 Miryam Sas, Fault Lines: Cultural Memory and Surrealism (Stanford, CA: Stanford University Press, 1999), 10-11.

9 Nakamura Giichi, Nihon kindai bijutsu ronsōshi, Zoku [History of Disputes in Japanese Modern Art, Continued] (Tokyo: Kyūryūdō, 1982), 197.

10 André Breton, Manifestoes of Surrealism, translated by Richard Seaver and Helen Lange (Ann Arbor: University of Michigan Press, 1974), 26.

11 Ibid., 9-14.

12 Maurice Nadeau, The History of Surrealism, translated by Richard Howard with an introduction by Roger Shattuck (New York: Macmillan, 1965), 104. 
13 Krzysztof Fijalkowski, 'Invention, Imagination, Interpretation: Collective Activity in the Contemporary Czech and Slovak Surrealist Group', Papers of Surrealism 3 (Spring 2005): 4.

14 David J. Lu, Japan: A Documentary History (Armonk, NY: M.E. Sharpe, 1997), 397.

15 James L. McClain, Japan, a Modern History (New York: W.W. Norton, 2002), 390.

16 Nadeau, The History of Surrealism, 164.

17 Ibid., 125.

18 Adachi Gen, 'Puroretaria bijutsu no shōchō: Kakumei no sensō no tame no bijutsu' [The Prosperity and Decay of Proletarian Art: Artistic Practice for the Revolutionary War], in Bijutsu no Nihon kingendaishi: Seido, gensetsu, zōkei [Histories of Modern and Contemporary Japan through Art: Institutions, Discourses, Practice], ed. Kitazawa Noriaki, Satō Dōshin and Mori Hitoshi (Tokyo: Tōkyō Bijutsu, 2014), 290.

19 George M. Beckmann and James W. Morley, Dilemmas of Growth in Prewar Japan (Princeton, NJ: Princeton University Press, 1974), 139-150.

20 John Clark, 'Abstract Subjectivity in the Taisho and Early Showa Avant-Garde', in Japanese Art after 1945: Scream against the Sky, ed. Alexandra Munroe, exh. cat. (New York: H.N. Abrams, 1994), 48.

21 I rely on a translation of this paragraph, as per Miwako Tezuka, 'Jikken Kōbō (Experimental Workshop): Avant-Garde Experiments in Japanese Art of the 1950s' (PhD diss., Columbia University, New York, 2005), 122-123.

22 Tōkyō Kokuritsu Kindai Bijutsukan (ed.), Shururearisumu ten [Exhibition of Surrealism], exh. cat. (Tokyo: Tōkyō Kokuritsu Kindai Bijutsukan, 1975), unpaginated.

23 Shigemi Inaga, 'The Impossible Avant-Garde in Japan, Does the Avant-Garde Exist in the Third World? Japan's Example: A Borderline Case of Misunderstanding in Aesthetic Intercultural Exchange', translated by Margaret J. Flynn, Yearbook of Comparative and General Literature 41 (1993): 67-75.

24 James M. Harding and John Rouse, 'Introduction', in Not the Other Avant-Garde: The Transnational Foundations of Avant-Garde Performance, ed. James M. Harding and John Rouse (Ann Arbor: University of Michigan Press, 2010), 6. For the expansion of this criticism in relation to such evolutions in the field as the division between 'centre' and 'periphery', see Per Bäckström and Benedikt Hjartarson, 'Rethinking the Topography of the International Avant-Garde: Introduction', in Decentring the Avant-Garde, ed. Per Bäckström and Benedikt Hjartarson (Amsterdam: Rodopi, 2014), 7-32.

25 Shūji Takashina, 'Introduction', in Japon des avant gardes, 1910-1970: Exposition, ed. Centre Georges Pompidou, exh. cat. (Paris: Éditions du Centre Pompidou, 1986), 23. See also John Clark, Modern Asian Art (Honolulu: University of Hawaii Press, 1998), 217-236.

26 Sas, Fault Lines, 35.

27 Oguma Eiji, A Genealogy of 'Japanese' Self-Images, translated by David Askew (Melbourne: Trans Pacific, 2002), xiii-xix.

28 For a rare mention of women Surrealist photographers in Japan, even in a context as late as Kon Michiko's practice in the 1990s, see Whitney Chadwick, 'An Infinite 
Play of Empty Mirrors: Women, Surrealism, and Self-Representation', in Mirror Images: Women, Surrealism, and Self-Representation, ed. Whitney Chadwick (Cambridge, MA: MIT Press, 1998), 28.

29 Breton, Manifestoes of Surrealism, 20.

30 Comte de Lautréamont, Maldoror and the Complete Works of Comte de Lautréamont, translated by Alexis Lykiard (Cambridge, MA: Exact Change, 1994), 193.

31 André Breton, What Is Surrealism? Selected Writings, edited and introduced by Franklin Rosemot (New York: Pathfinder, 2012), 15. André Breton, Surrealism and Painting, translated by Simon Watson Taylor (New York: Monad, 1972), 32.

32 Salvador Dalí, 'Photography: Pure Creation of the Mind', in The Sources of Surrealism: Art in Context, ed. Neil Matheson (Aldershot: Lund Humphries, 2006), 373.

33 Rosalind Krauss, The Originality of the Avant Garde and Other Modernist Myths (Cambridge, MA: MIT Press, 1985), 87-118.

34 Ian Walker, City Gorged with Dreams: Surrealism and Documentary Photography in Interwar Paris (Manchester: Manchester University Press, 2002), 8.

35 Margaret Plant, 'Shopping for the Marvellous: The Life of the City in Surrealism', in Surrealism: Revolution by Night, ed. Michael Lloyd, exh. cat. (Canberra: National Gallery of Australia, 1993), 156.

36 Marja Warehime, Brassaï: Images of Culture and Surrealist Observer (Baton Rouge: Louisiana State University Press, 1996), 41.

37 Susan Sontag, On Photography (New York: Farrar, Strauss and Giroux, 1977), 40.

38 David Bate, Photography and Surrealism: Sexuality, Colonialism and Social Dissent (London: I.B. Tauris, 2003). Ian Walker, So Exotic, So Homemade: Surrealism, Englishness and Documentary Photography (Manchester: Manchester University Press, 2007). Krzystof Fijalkowski, Michael Richardson and lan Walker, Surrealism and Photography in Czechoslovakia: On the Needles of Days (London: Routledge, 2016). Patricia Allmer, Lee Miller: Photography, Surrealism, and Beyond (Manchester: Manchester University Press, 2016).

39 Édouard Jaguer, Les Mystères de la chambre noire: Le Surréalisme et la photographie (Paris: Flammarion, 1982), 111-112.

40 Rosalind Krauss and Jane Livingstone (eds), L'Amour fou: Photography and Surrealism, exh. cat. (New York: Abbeville Press, 1986), 9.

41 Quentin Bajac et al., 'Changer la vue', in La Subversion des images, surréalisme, photographie, film, ed. Quentin Bajac and Clément Chéroux, exh. cat. (Paris: Édicion du Centre Pompidou, 2009), 18. For a similar precedent, see Monika Faber et al., Das Innere der Sicht: Surrealistische Fotografie der 30er und 40er Jahre: Ausstellungskatalog (Vienna: Osterreichisches Fotoarchiv, 1989).

42 Durozoi, History of the Surrealist Movement, 334-336.

43 I draw this conclusion from my correspondence and two interviews with Kurosawa Yoshiteru, biographer of the artist, conducted in December 2012 and January 2013. Although Kurosawa provided detailed information about the image's existence in his studies, he has not seen it prior to its inclusion in the exhibition catalogue.

44 Naomi Rosenblaum, A World History of Photography (New York: Abbeville Press, 1997), 413. Anne Wilkes Tucker et al., The History of Japanese Photography, exh. 
cat. (New Haven, CT: Yale University Press, 2003), 9. Martin Parr and Gerry Badger, The Photobook, Volume 1 (London: Phaidon Press, 2007), 113.

45 Tōkyō-to Shashin Bijutsukan (ed.), Nihon kindai shashin no seiritsu to tenkai [The Founding and Development of Modern Photography in Japan], exh. cat. (Tokyo: Tōkyō-to Shashin Bijutsukan, 1995), 2.

46 Nakayama Iwata had a retrospective exhibition with the Ashiya City Museum of Art and History in 2003, Yasui Nakaji's retrospective travelled between Shoto Museum of Art in Tokyo and Nagoya City Art Museum in 2004 and 2005 whereas Miyazaki Prefectural Art Museum, the Museum of Modern Art, Saitama, Urawa Art Museum and the Japan Association of Art Museum celebrated Ei-Kyū's 100th birth anniversary with an exhibition in 2011.

47 For groundbreaking research in the area that first introduced the Western readership to a number of original Surrealist texts published in Japanese, see Vera Linhartová, Dada et surréalisme au Japon (Paris: Publications Orientalistes de France, 1987). The same approach was adopted in John Clark, Surrealism in Japan (Clayton, VIC: Monash Asia Institute, Japanese Studies Centre, 1997).

48 John Solt, 'Perception, Misperception, Nonperception', in Yamamoto Kansuke: Conveyor of the Impossible, ed. Yamamoto Kansuke et al., exh. cat. (Tokyo: Tokyō Sutēshion Gyararī, 2001), 19-67. For more recent studies, see Majella Munro, Communicating Vessels: The Surrealist Movement in Japan, 1923-1970 (Cambridge: Enzo Press, 2012), 19. See also Amanda Maddox, 'Disobedient Spirit: Kansuke Yamamoto and His Engagement with Surrealism', in Japan's Modern Divide: The Photographs of Hiroshi Hamaya and Kansuke Yamamoto, ed. Judith Keller and Manda Maddox, exh. cat. (Los Angeles: J. Paul Getty Museum, 2013), 183.

49 Nagoya-shi Bijutsukan, Nihon no shūrurearisumu: 1925-1945, 180-202.

50 Wada Hirofumi (ed.), Korekushon Nihon shürurearisumu [Collection of Surrealism in Japan] (Tokyo: Hon no Tomosha, 1999-2001).

51 Solt, 'Perception, Misperception, Nonperception', 3. Nishimura Tomohiro allocates a more prominent role to Surrealism in the 'Photography and Avant-Garde' chapter of his history of Japanese art photography, although largely drawing on artist biographies to support his arguments, as in Nishimura Tomohiro, Nihon geijutsu shashinshi: Ukiyo-e kara dejikame made [History of Art Photography in Japan: from Ukiyo-e to Digital Camera] (Kokubunji: Bigaku Shuppan, 2008), 215-292. Also, an equally significant attempt was made to engage more critically with photographic Surrealism in an exhibition at the Gunma Museum of Art, Tatebayashi, as in Gunma Kenritsu Tatebayashi Bijutsukan (ed.), Yume no naka no shizen: Shōwa shoki no shururearisumu kara gendai no kaiga e [Nature in Dreams: From Surrealism in the Early Shōwa to Contemporary Painting], exh. cat. (Gunma: Gunma Kenritsu Tatebayashi Bijutsukan, 2006), 76-95. The exhibition catalogue assigns a full section to photographic practices, recognizing a strong presence of Surrealism in Japanese art of the 1930s.

\section{Chapter 1}

1 Henry Smith, 'Tokyo as an Idea: An Exploration of Japanese Urban Thought Until 1945', Journal of Japanese Studies 4, no. 1 (1978): 69-71. Miriam Silverberg, Erotic 
Grotesque Nonsense: The Mass Culture of Japanese Modern Times (Berkeley: University of California Press, 2006), 29.

2 lizawa Kōtarō, Shashin ni kaere: 'Kōga' no jidai [Return to Photography: The Age of Kōga] (Tokyo: Heibonsha, 1988), 32.

3 Omuka Toshiharu, Taishōki shinkō bijutsu undō no kenkyū [The Japanese Modern Art Movement and the Avant-Garde, 1920-1927] (Tokyo: Sukaidoa, 1995).

4 William O. Gardner, 'New Perceptions: Kinugasa Teinosuke's Films and Japanese Modernism', Cinema Journal 43, no. 3 (2004): 67.

5 Chinghsin Wu, 'Transcending the Boundaries of the "isms": Pursuing Modernity through the Machine in 1920s and 1930s Japanese Avant-Garde Art', in Rethinking Japanese Modernism, ed. Roy Starrs (Leiden: Brill, 2012).

6 Koga Harue, 'Chōgenjitsushugi shikan' [Personal Observations about Surrealism], in Korekushon Nihon shūrurearisumu 15: Shūrurearisumu kihon shiryō shūsei [Collection of Surrealism in Japan 15: Surrealism, Collection of Fundamental Documents], ed. Wada Hirofumi (Tokyo: Hon no Tomosha, 2001), 82.

7 Christine Kuhn, 'Film und Foto International Exhibition', in Tōkyō-Berurin/BerurinTōkyō ten [Tokyo-Berlin/Berlin-Tokyo], ed. Mori Bijutsukan, exh. cat. (Tokyo: Mori Bijutsukan, 2006).

8 lizawa Kōtarō, 'Nihon no shashinka tachi to Berurin' [Japanese Photographers and Berlin], in Tōkyō- Berurin/Berurin-Tōkyō ten [Tokyo-Berlin/Berlin-Tokyo], ed. Mori Bijutsukan, exh. cat. (Tokyo: Mori Bijutsukan, 2006), 37. For detailed analysis of the responses to the exhibition, see lizawa, Shashin ni kaere, 50-54.

9 Ina Nobuo, Shashin, Shōwa gojūnenshi [Photography, History of Fifty Years of Shōwa] (Tokyo: Asahi Shinbunsha, 1978), 34.

10 Masuda Rei, 'Shōwa senzen mae to Onchi Kōshirō, Shiihara Osamu, Ei-Kyū' [Japanese Photography of the 1920s and 1930s: Photographic Works of Koshiro Onchi, Osamu Shiihara and Ei- kyu], translated by Kikugo Ogawa, in Modanizumu no kōseki: Onchi Kōshirō, Shiihara Osamu, Ei-Kyū [Traces of Light in Modernism: Koshiro Onchi, Osamu Shiihara and Ei-Kyu], ed. Tōkyō Kokuritsu Kindai Bijutsukan, exh. cat. (Tokyo: Tōkyō Kokuritsu Kindai Bijutsukan, 1997), 8. See also Fujimura Satomi, 'Shinkō shashin to wa nandatta no ka' [What Was New Photography], in Kōga to shinkō shashin: Modanizumu no Nihon [The Magazine and the New Photography: KOGA and Japanese Modernism], ed. Tōkyō-to Shashin Bijutsukan, exh.cat. (Tokyo: Kokusho Kankōkai, 2018).

11 lizawa, Shashin ni kaere, 47.

12 lizawa Kōtarō, 'Modanizumu to shite no shinkō shashin' [New Photography and Modernism], in Nihon Modanizumu no kenkyū: Shisō, seikatsu, bunka [Study of Japanese Modernism: Thought, Life, Culture], ed. Minami Hiroshi (Tokyo: Burēn Shuppan, 1982), 209.

13 lizawa Kōtarō, Toshi no shisen: Nihon no shashin 1920-30 nendai [The View of the City: Japanese Photography in the 1920s-1930s] (Osaka: Sōgensha, 1989), 17. See also Kerry Ross, Photography for Everyone, The Cultural Lives of Cameras and Consumers in Early Twentieth-Century Japan (Stanford, CA: Stanford University Press, 2015), 8.

14 Itagaki Takao, Kikai to geijutsu to no kōryū [The Correspondence between Machine and Art] (Tokyo: Iwanami Shoten, 1929). See also Kanamaru Shigene, Shinkō shashin no tsukurikata [How to Make New Photography] (Tokyo: Genkōsha, 1932). 
15 Ina Nobuo, 'Shashin ni kaere' [Return to Photography], in Shashin ni kaere [Return to Photography: Japanese Photography of the 1930s], ed. Zen Foto Gallery (Tokyo: Zen Foto Gallery, 2010), 8. I rely on the translation of the original text provided in this volume.

16 For all issues of the magazines, see lizawa Kōtarō (ed.), Kōga [Pictures of Light] (Tokyo: Fukkokuban 'Kōga' Kankōkai, 1990). See also Tōkyō-to Shashin Bijutsukan (ed.), Kōga to shinkō shashin: Modanizumu no Nihon [The Magazine and the New Photography: KOGA and Japanese Modernism], exh.cat. (Tokyo: Kokusho Kankōkai, 2018).

17 Silverberg, Erotic Grotesque Nonsense, 31.

18 Nishimura, Nihon geijutsu shashinshi, 234.

19 Nakayama Iwata, 'Jun geijutsu shashin' [Pure Art Photography], Asahi kamera 5, no. 1 (1928): 40. Mitsuda Yuri, 'Kukkyoku to kirameki, Nakayama Iwata no sakuhin to jidai' [Flexure and Glitter: Nakayama Iwata's Work and Its Time], in Nakayama Iwata ten: Modan fotogurafi [Nakayama Iwata: Modern Photography], ed. Ashiya Shiritsu Bijutsu Hakubutsukan, exh. cat. (Kyoto: Tankōsha, 2003), 265.

20 Nakayama Iwata, 'Jun geijutsu shashin', 40.

21 Although there is no record of these photographs, three of them are known to have been solarizations, as in Ashiya Shiritsu Bijutsu Hakubutsukan (ed.), Ashiya Kamera Kurabu 1930-1942: Ashiya no bijutsu o saguru [Ashiya Camera Club 1930-1942: Exploring the Beauty of Ashiya] (Ashiya: Ashiya Shiritsu Bijutsu Hakubutsukan, 1998), 7.

22 Breton, Surrealism and Painting, 32.

23 Takiguchi, 'Chōgenjitsushugi to kaiga', 109-212.

24 Takiguchi Shūzō, 'Man Rei' [Man Ray], in Korekushon Nihon shūrurearisumu 3: Shūrurearisumu no shashin to hihyō [Collection of Surrealism in Japan 3: Surrealist Photography and Criticism], ed. Takeba Jō (Tokyo: Hon no Tomosha, 2000).

25 Arturo Schwartz, Man Ray, The Rigour of Imagination (London: Thames and Hudson, 1977), 236-237.

26 Mitsuda, 'Kukkyoku to kirameki', 269.

27 Wada Hirofumi (ed.), Korekushon Nihon shūrurearisumu 15: Shūrurearisumu kihon shiryō shūsei [Collection of Surrealism in Japan 15: Surrealism, Collection of Fundamental Documents] (Tokyo: Hon no Tomosha, 2001), 477. Moriguchi Tari, Pari shinkō kaiga senshū [Collection of New Art in Paris] (Tokyo: Heibonsha, 1933).

28 Wada, Korekushon Nihon shürurearisumu 15, 478.

29 Matsumi Teruhiko, Kōkoku shashin no modanizumu: Shashinka Nakayama Iwata to 1930 nendai [Modernity in Commercial Photography: Photography of Nakayama Iwata and the 1930s] (Tokyo: Seikyūsha, 2015), 42-44.

30 Nagoya-shi Bijutsukan, Nihon no shūrurearisumu: 1925-1945, 50.

31 Pari Tōkyō Shinkō Bijutsu tenrankai mokuroku [Catalogue of the Exhibition of New Art in Paris and Tokyo], in Korekushon Nihon shūrurearisumu 15: Shūrurearisumu kihon shiryō shūsei [Collection of Surrealism in Japan 15: Surrealism, Collection of Fundamental Documents], ed. Wada Hirofumi (Tokyo: Hon no Tomosha, 2001).

32 Ibid., 158-161. 
33 Namigata Tsuyoshi, Ekkyō no avangyarudo [Border-Crossing Avant-Garde] (Tokyo: NTT Shuppan, 2005).

34 Adachi Gen, Zen'ei no idenshi: Anakizumu kara sengo bijutsu e [Memes of the Japanese Avant-Garde: From Anarchism to Postwar Art] (Kunitachi: Buryukke, 2012), 173-176.

35 Sandra Wilson, The Manchurian Crisis and Japanese Society, 1931-33 (London: Routledge, 2002), 2.

36 Mitsuda Yuri, 'Shōwa zenki no bijutsukai to shashin sakuhin' [Art World and Photographic Works in the Early Part of Shōwa], in Shōwaki bijutsu tenrankai no kenkyū: Senzenhen [Research into Art Exhibitions in Shōwa Era, Prewar Edition], ed. Tōkyō Bunkazai Kenkyūjo Kikaku Jōhōbu [Tokyo National Research Institute for Cultural Properties] (Tokyo: Chūō Kōron Bijutsu Shuppan, 2009), 382. The 'art world' was commonly referred to in Japanese of the time as bijutsukai whereas the 'photography world' was referred to as shashinkai.

37 Sawa Masahiro and Wada Hirofumi (eds), Nihon no Shūrurearisumu [Japanese Surrealism] (Tokyo: Sekai Shisōsha, 1995). Wada, Korekushon Nihon shūrurearisumu 15. Tsuruoka Yoshihisa (ed.), Korekushon, Toshi modanizumu shishi 3, Shūrurearisumu [Collection: Poetry and Illustration of Urban Modernity Volume 3, Surrealism] (Tokyo: Yumani Shobō, 2009). Nishimura Masahiro (ed.), Korekushon, Toshi modanizumu shishi 14: VOU Kurabu no jikken [Collection: Poetry and Illustration of Urban Modernity Volume 14: Experiments of VOU Club] (Tokyo: Yumani Shobō, 2011). Sawa Masahiro (ed.), Korekushon, Toshi modanizumu shishi 15: VOU Kurabu to jūgonen sensō [Collection: Poetry and Illustration of Urban Modernity, Volume 15: VOU Club and Fifteen Year War] (Tokyo: Yumani Shobō, 2011).

38 Wilson, The Manchurian Crisis, 31.

39 Morris Low, Japan on Display: Photography and the Emperor (London: Routledge, 2006), 58-77. Wilson, The Manchurian Crisis, 30.

40 Editor's Remarks, Asahi kamera, 13/5 (1932), 548.

41 Koishi Kiyoshi, Shoka shinkei [Early Summer Nerves] (Tokyo: Kokusho Kankōkai, 2005).

42 Ina Nobuo, “'Kōgakai” ni tsuite’ [Kōga Meeting], Kōga 2, no. 6 (1933): 156-157.

43 Ina Nobuo, 'Shashinkai e no kōkaijō (II)' [An Open Letter Addressed to the Photography World (II)], Kōga 2, no.10 (1933): 253.

44 Ibid., 254.

45 Takeba Joe, 'The Age of Modernism: From Visualization to Socialization', in The History of Japanese Photography, ed. Anne Wilkes Tucker et al. (New Haven, CT: Yale University Press, 2003), 148. I rely on Takeba's translation of this phrase.

46 Yamawaki Iwao, 'Naniga okashii' [ls There Something Funny?], in Korekushon Nihon shūrurearisumu 3: Shūrurearisumu no shashin to hihyō [Collection of Surrealism in Japan 3: Surrealist Photography and Criticism], ed. Takeba Jō (Tokyo: Hon no Tomosha, 2001), 52.

47 Ibid.

48 Yamawaki Iwao, 'Nihon no fotomontāju o miru' [Looking at Japanese Photomontage], in Korekushon Nihon shūrurearisumu 3: Shūrurearisumu no shashin 
to hihyō [Collection of Surrealism in Japan 3: Surrealist Photography and Criticism], ed. Takeba Jō (Tokyo: Hon no Tomosha, 2001), 54.

49 Koishi Kiyoshi, 'Seimei no gangu' [Life's Toys], in Korekushon Nihon shürurearisumu 3: Shürurearisumu no shashin to hihyō [Collection of Surrealism in Japan 3:

Surrealist Photography and Criticism], ed. Takeba Jō (Tokyo: Hon no Tomosha, 2001).

50 lbid., 63-65.

51 Ibid., 66. Roland Barthes, Camera Lucida: Reflections on Photography, translated by Richard Howard (London: Vintage Books, 2000), 10-15.

52 Koishi Kiyoshi, 'Shinkankaku no hyōgen: Riarizumu no kanata e' [Expressions of New Sensibility: Going Beyond Reality], Kamera āto, June Edition (1935): 150.

53 Ibid., 151.

54 Koishi Kiyoshi, Satsuei: Sakuga no shingihō [Photography: A New Method for Image-Making] (Tokyo: Genkōsha, 1936).

55 Gennifer Weisenfeld, 'Touring Japan-as-Museum: NIPPON and Other Japanese Imperial Travelogues', positions: east asia culture critique 8, no. 3 (2000): 747-793.

56 Ibid., 752-754.

57 Silverberg, Erotic Grotesque Nonsense, 3. See also Omuka Toshiharu, Hijōji no modanizumu: 1930 nenndai teikoku Nihon no bijutsu [Modernism in a Time of Crisis: Art in 1930s Imperial Japan] (Tokyo: Tokyō Daigaku Shuppankai, 2017), 1-17.

58 Koishi, 'Seimei no gangu', 80.

59 Sugita Hideo, 'Fotoguramu no jiyū na seisaku no tame ni' [For a Free Production of Photograms], in Korekushon Nihon shürurearisumu 14: Ei-Kyū, Shimozato Yoshio, renzu no avangyarudo [Collection of Surrealism in Japan 14: Ei-Kyū, Shimozato Yoshio, Avant-Garde of the Lens], ed. Yamada Satoshi (Tokyo: Hon no Tomosha, 2001).

60 For a detailed biography of the artist, see Yamada Kōshun, Ei-Kyū: Hyōden to sakuhin [Ei-Kyū: Critical Biography and Artworks] (Tokyo: Kabushiki Kaisha Seiryūdō, 1976).

61 Sugita, 'Fotoguramu no jiyū na seisaku no tame ni', 43.

62 Referred to in a loanword from French as étranger, as per lbid.

63 Silverberg, Erotic Grotesque Nonsense, 53. Donald Richie, 'Foreword', in The Scarlet Gang of Asakusa, ed. Yasunari Kawabata (Berkeley: University of California Press, 2005), xviii.

64 Yamada, Ei-Kyū, 76.

65 Ibid., 115.

66 Ibid.

67 For more details about Fukuzawa's use of the illustrated press, see Ōtani Shōgo, 'Fukuzawa Ichrō to korāju: 1930 nendai shoki ni okeru shūrurearisumu juyōo megutte' [Ichiro Fukuzawa and Collage: A Japanese Artist's Adoption of Surrealism in the Early 1930s], Tõkyō Kokuritsu Kindai Bijutsukan Kenkyū Kiyō [Bulletin of the National Museum of Modern Art] 5 (1996): 55-76.

68 Yamada, Ei-Kyū, 119. 
69 Ibid., 124-125.

70 Ei-Kyū, 'Gendai seikatsu to hikari to kage to: Foto dessan no sakusha to shite no kansō' [Modern Life, Light and Shadow: Impressions of a Photo-Drawing's Creator], Hōmu raifu 2, no. 8 (1936): 28.

71 Ei-Kyū, 'Genjitsu ni tsuite’ [On Reality], Atorie 14, no. 6 (1937): 71-74.

72 Ibid., 71.

73 lbid., 73.

74 Rosalind Krauss, 'Photography in the Service of Surrealism', in L'Amour fou: Photography and Surrealism, ed. Rosalind Krauss and Jane Livingstone, exh. cat. (New York: Abbeville Press, 1986), 24-25. Bate, Photography and Surrealism, 9.

75 David Bate, 'Introduction', History of Photography 29, no. 2 (2015): 97-98.

76 Ishii Ayako, '“Zen'ei” ga kagayaita kisetsu' [The Season of Bright 'Avant-Garde'], in Nihon no shashinka 15: Koishi Kiyoshi to zen'ei shashin [Complete Collection of Japanese Photographers 15: Koishi Kiyoshi and Avant-Garde Photography], ed. Nagano Shigeichi, lizawa Kōtarō and Kinoshita Naoyuki (Tokyo: Iwanami Shoten, 1999), 62-63.

77 Mitsuda, 'Shōwa zenki no bijutsukai to shashin sakuhin', 379. The organization was officially dissolved in 1928, with its faction National Painting Society (Kokugakai) keeping the name of the exhibition.

78 I am grateful to Ōtsuki Akimi at the Ashiya City Museum of Art and History for sharing information about Matsubara and for showing me his work during my visit to the museum in April 2017.

79 Ashiya Shiritsu Bijutsu Hakubutsukan, Ashiya Kamera Kurabu 1930-1942, 22.

80 Matsubara Jūzō, Kaihō sareta kūsō [Liberated Fantasy], Nihon shashin nenkan (1936-37): 12. This remark is made in the comments that all photographers supplied to the Annual, including technical specs of their images. Matsubara references a 'research into Rimbaud's love' but misspells Rimbaud's name as Rabō rather than Ranbō in Japanese. In the same volume, the Index of works in English also misspells the title of Matsubara's work as A Fantacy.

81 Harry D. Harootunian, History's Disquiet: Modernity, Cultural Practice and the Question of Everyday Life (New York: Columbia University Press, 2000), 116.

82 Peter Eckersall, 'From Liminality to Ideology: The Politics of Embodiment in Prewar Avant-Garde Theatre in Japan', in Not the Other Avant-Garde, ed. James Harding and John Rouse (Ann Arbor: University of Michigan Press, 2006), 231.

83 Matsubara Jūzō, 'Torikku shashin no utsushikata' [How to Make Trick Photographs], Asahi kamera 27, no. 2 (1939): 298-299.

84 Nakada Sadanosuke, 'Kokuten no shashin' [Photography at the National Exhibition], Mizue, no. 415 (1939): 16. The review includes Matsubara's Contrast (Kontorasuto), an assemblage that attests to the same abstracting tendency as in Ei-Kyū's work. Other photographers who exhibited at the show include Nakayama Iwata and Hanaya Kanbei.

85 Clément Chéroux, 'The Avant-Garde of Amateurs', in Photography: A New Vision of the World 1891-1940, ed. Gerry Badger and Walter Guadagnini (Milan: Skira, 2012), 23.

86 Ibid., 15. 
87 Ibid., 25.

88 Takeba, 'The Age of Modernism', 138.

89 Kaneko Maki, 'Seido to shakai' [Institutions and Society], in Bijutsu no Nihon kingendaishi: Seido, gensetsu, zōkei [Histories of Modern and Contemporary Japan through Art: Institutions, Discourses, Practice], ed. Kitazawa Noriaki, Satō Dōshin and Mori Hitoshi (Tokyo: Tōkyō Bijutsu, 2014), 458.

\section{Chapter 2}

1 Nagoya-shi Bijutsukan, Nihon no shūrurearisumu: 1925-1945, 74.

2 Omuka Toshiharu (ed.), Korekushon Nihon shūrurearisumu 2: Shūrurearisumu no bijutsu to hihyō [Collection of Surrealism in Japan 2: Surrealist Art and Criticism] (Tokyo: Hon no Tomosha, 2001), 397.

3 Adolf Behne's Von Kunst zur Gestaltung (1925) was a significant point of reference, as per Omuka, Taishōki shinkō bijutsu, 769.

4 Takizawa Kyōji, 'Avangyarudo kara puroretaria bijutsu e: Bijutsu seido no yōdō to kaihen' [From Avant-Garde to Proletarian Art: The Shaking and Reorganisation of Art Institutions], in Bijutsu no Nihon kingendaishi: Seido, gensetsu, zōkei [Histories of Modern and Contemporary Japan through Art: Institutions, Discourses, Practice], ed. Kitazawa Noriaki, Satō Dōshin and Mori Hitoshi (Tokyo: Tōkyō Bijutsu, 2014), 243.

5 Omuka, Korekushon Nihon shūrurearisumu 2, 382.

6 Aoki Shigeru and Tōkyō Kokuritsu Bunkazai Kenkyūjōo (eds.), Kindai Nihon āto katarogu korekushon 73: Jiyū Bijutsu Kyōkai, Bijutsu Sōsakka Kyōkai [Collection of Modernist Japanese Art Catalogues Vol. 73: Free Artists' Association and Art Creatives' Association] (Tokyo: Yumani Shobō, 2004).

7 Mitsuda, 'Shōwa zenki no bijutsukai to shashin sakuhin', 382-383. For collage's historical development in Japan, see Fujimura Satomi, 'Korāju to fotomontāju: Shashin reimeiki no fotomontāju kara Nihon no shashin ni okeru korāju no juyō made' [Collage and Photomontage: From Photomontage at the Dawn of Age of Photography to Reception of Collage in Japanese Photography], Tōkyō-to Shashin Bijutsukan, Kiyō [The Bulletin: Tokyo Metropolitan Museum of Photography] 6 (2007): 28-38.

8 For an overview, see Reiko Tomii, 'Introduction: Collectivism in Twentieth-Century Japanese Art with a Focus on Operational Aspects of Dantai', positions: east asia cultures critique 21, no. 2 (2013): 225-267.

9 Philippe-Alain Michaud, 'La coalescence et la suture', in La Subversion des images, surréalisme, photographie, film, ed. Quentin Bajac and Clément Chéroux, exh. cat. (Paris: Éditions du Centre Pompidou, 2009), 176.

10 Sigmund Freud, The Interpretation of Dreams, translated by Joyce Crick, introduction and notes by Richie Robertson (Oxford: Oxford University Press, 1999), 137.

11 For further details about this exhibition, see Cristina Garbagna, Collages: From Cubism to New Dada (Milan: Electa, 2007), 280-281. See also Brandon Taylor, Collage: The Making of Modern Art (London: Thames and Hudson, 2004), 57-58. 
12 Takiguchi refers Japanese readers interested in collage to Aragon's text only a year after, as per Takiguchi, 'Man Rei', 6.

13 Imai Shigeru, 'Kaiga ni okeru montaju ni tsuite' [Montage in Painting], in Korekushon Nihon shūrurearisumu 2: Shūrurearisumu no bijutsu to hihyō [Collection of Surrealism in Japan 2: Surrealist Art and Criticism], ed. Omuka Toshiharu (Tokyo: Hon no Tomosha, 2001), 65.

14 Ibid.

15 Louis Aragon, 'The Challenge to Painting', in The Surrealists Look at Art, ed. Pontus Hulten (Venice, CA: Lapis Press, 1990), 54.

16 Ibid., 55-56.

17 Ibid., 65.

18 Imai Shigeru, 'Kaiga ni arawareta katsuji ni taisuru nōto' [A Note on the Printed Material in Painting], in Korekushon Nihon shūrurearisumu 2: Shürurearisumu no bijutsu to hihyō [Collection of Surrealism in Japan 2: Surrealist Art and Criticism], ed. Omuka Toshiharu (Tokyo: Hon no Tomosha, 2001), 76.

19 Breton, Manifestoes of Surrealism, 123-124.

20 Kurosawa Yoshiteru (ed.), Yamanaka Chirū shoshi nenpu [Yamanaka Tiroux Chronologie et Bibliographie] (Tokyo: Tanseisha, 2005), 126-127. The exhibition travelled to Nagoya from its third instalment, after Yamanaka and Shimozato joined the group.

21 Breton's image is described in Clara Elizabeth Orban, The Culture of Fragments: Words and Images in Futurism and Surrealism (Amsterdam: Rodopi, 1997), 110-111.

22 The general composition of the image also resonates with Georges Hugnet's work. For Yamanaka's writing about Hugnet, see Yamanaka Chirū, 'Chōgenjitsushugi to wa nanika' [What Is Surrealism], in Korekushon Nihon shürurearisumu 6: Yamanaka Chirū, 1930 nendai no oruganaizā [Collection of Surrealism in Japan 6: Yamanaka Chirū, Organiser of the 1930s], ed. Kurosawa Yoshiteru (Tokyo: Hon no Tomosha, 1999). Hugnet's correspondence with Yamanaka is held in the Yamanaka Chirū Archive at the Keio Hiyoshi Library and I am grateful to Professor Kasai Hiroyuki for showing me the collection in April 2017.

23 Michel Foucault, This Is Not a Pipe (Berkeley: University of California Press, 1983), 36.

24 Ibid., 21.

25 Harry Bober, 'The Zodiacal Miniature of the Très Riches Heures of the Duke of Berry - Its Sources and Meaning', Journal of the Warburg and Courtauld Institutes 11 (1948): 1

26 Ibid., 18.

27 Rosalind Krauss, 'Grids', October 9 (1979): 59.

28 Yamanaka Chirū, 'POCO A POCO, Saikin no gashū no shōkai' [POCO A POCO, Introducing the Recent Illustrated Albums], in Korekushon Nihon shürurearisumu 6: Yamanaka Chirū, 1930 nendai no oruganaizā [Collection of Surrealism in Japan 6: Yamanaka Chirū, Organiser of the 1930s], ed. Kurosawa Yoshiteru (Tokyo: Hon no Tomosha, 1999). 
29 Yamanaka Chirū, 'Chōgenjitsushugi no taishō' [The Subject of Surrealism], in Korekushon Nihon shūrurearisumu 6: Yamanaka Chirū, 1930 nendai no oruganaizā [Collection of Surrealism in Japan 6: Yamanaka Chirū, Organiser of the 1930s], ed. Kurosawa Yoshiteru (Tokyo: Hon no Tomosha, 1999).

30 Kurosawa, Yamanaka Chirū shoshi nenpu, 12.

31 Yamanaka, 'Chōgenjitsushugi no taishō', 416.

32 David Gascoyne, 'Introduction', in The Automatic Message; The Magnetic Fields; The Immaculate Conception, ed. André Breton, Paul Éluard and Philippe Soupault, translated by David Gascoyne, Antony Melville and Jon Graham, introduced by David Gascoyne and Antony Melville (London: Atlas Press, 1997), 45.

33 Catriona McAra, 'Surrealism's Curiosity: Lewis Carroll and the Femme-Enfant', Papers of Surrealism 9 (Summer 2011): 1-25.

34 Haim Finkelstein, 'Screen and Layered Depth: Surrealist Painting and the Conceptualization of the Mental Space', Res: Anthropology and Aesthetics 51 (2007): 183.

35 Haim Finkelstein, The Screen in Surrealist Art and Thought (Burlington, VT: Ashgate, 2007).

36 Yamanaka, 'Chōgenjitsushugi no taishō', 416. Yamanaka distinguishes between photomontage and photo-collage in that the latter is a product of an irrational mind (418).

37 With 'photo-object' referred to in Japanese as foto obuje in a loanword and is translated as buttai shashin, as per lbid., 417.

38 Kurosawa, Yamanaka Chirū shoshi nenpu, 160.

39 Three of these drawings were also seen in the Nagoya exhibition in February 1936, as per Ibid., 126. The Japanese translation is titled Aru isshō no uchimaku arui wa ningen no sentō.

40 This exhibition also travelled to Nagoya in June 1937 but the exhibition catalogue there lists the names of works in a different manner and does not record the reproductions of foreign Surrealist works seen in Tokyo in March, as in Ibid., 127.

41 Five of the exhibited reproductions are included in Nagoya-shi Bijutsukan, Nihon no shürurearisumu: 1925-1945, 83. A detailed list of these works is provided in Kurosawa, Yamanaka Chirū shoshi nenpu, 162-163.

42 Yamanaka Chirū, 'Shururearisumu shisō no kokusaika: Kōki ni kaete' [Internationalisation of Surrealist Thought: A Postscript], in Korekushon Nihon shūrurearisumu 15: Shūrurearisumu kihon shiryō shūsei [Collection of Surrealism in Japan 15: Surrealism, Collection of Fundamental Documents], ed. Wada Hirofumi (Tokyo: Hon no Tomosha, 2001), 265. Titled in the table of contents in French and over ten pages long, Yamanaka's article is contextualized as a 'postscript' to the collection of mostly translated Surrealist texts, for which he is accredited as an editor (directeur), as per Yamanaka Chirū (ed.), L'Échange surréaliste, in Korekushon Nihon shūrurearisumu 15: Shūrurearisumu kihon shiryō shūsei [Collection of Surrealism in Japan 15: Surrealism, Collection of Fundamental Documents], ed. Wada Hirofumi (Tokyo: Hon no Tomosha, 2001). The compilation also includes a set of Takiguchi's 
poems titled by the names of several Surrealist artists (Ernst, Dali, Magritte, Miró, Picasso, Man Ray and Tanguy).

43 Yamanaka, 'Shururearisumu shisō', 266-267. For the original quote, see Breton, Manifestoes of Surrealism, 262.

44 Ibid.

45 Ibid., 268-275.

46 Kaigai Chōgenjitsushugi Sakuhinshū: ALBUM SURRÉALISTE [Collection of Foreign Surrealist Works: Surrealist Album], Mizue 388 (1937). Takiguchi wrote the introductory note and translated captions into Japanese whereas everything else was compiled by Yamanaka.

47 Ibid., 1.

48 'Le surréalisme autour du monde', Minotaure 10, no. 3 (1937): unpaginated.

49 Yamanaka's 'POCO A POCO' is an example how substantial part of this exchange took place through correspondence. As the materials held in the Yamanaka Chirū Archive at the Keio Hiyoshi Library and at the Scottish National Gallery of Modern Art Archive attest, it was Penrose who sent the Surrealist publications to Yamanaka, who in turn sent Penrose his review of this literature once it was published.

50 Nagoya-shi Bijutsukan, Nihon no shūrurearisumu: 1925-1945, 92.

51 André Breton and Paul Éluard, Dictionnaire abrégé du surréalisme, exh. cat. (Paris: Galerie Beaux-Arts, 1938), 37 and 66.

52 Ibid., 27 and 30.

53 Yamanka Chirū, 'Kaigai Chōgenjitsushugi Sakuhin ten hōkokusho' [Report about the Exhibition of Foreign Surrealist Works], in Korekushon Nihon shürurearisumu 6: Yamanaka Chirū, 1930 nendai no oruganaizā [Collection of Surrealism in Japan 6: Yamanaka Chirū, Organiser of the 1930s], ed. Kurosawa Yoshiteru (Tokyo: Hon no Tomosha, 1999). Yamanka is here clearly referring to Man Ray as a European artist. A letter sent to Yamanaka from Alfred Barr, director at MoMA in New York, addressed on 7 January 1937, testifies that Yamanaka made an effort to include American artists but was told by Barr that there is not really a very wide interest in Surrealism in the country as of yet. The letter is held in the Yamanaka Chirū Archive at the Keio Hiyoshi Library.

54 Ibid., 405.

55 Yamada Satoshi, 'Shūrurearisumu kaiga no taidō (1934-1937)' [Awakening of Surrealist Painting (1934-1937)], in Nihon no shürurearisumu: 1925-1945 [Surrealism in Japan: 1925-1945], ed. Nagoya- shi Bijutsukan, exh. cat. (Nagoya: Nihon no Shūrurearisumuten Jikkō linkai, 1990), 74-75.

56 Yamanaka Chirū, 'Atarashii foto korāju' [New Photo-Collage], in Korekushon Nihon shūrurearisumu 6: Yamanaka Chirū, 1930 nendai no oruganaizā [Collection of Surrealism in Japan 6: Yamanaka Chirū, Organiser of the 1930s], ed. Kurosawa Yoshiteru (Tokyo: Hon no Tomosha, 1999).

57 For the relationship between the game and Freud's writing, see Anne M. Kern, 'From One Exquisite Corpse (in)to Another: Influences and Transformations from Early to Late Surrealist Games', in The Exquisite Corpse: Chance and Collaboration in Surrealism's Parlor Game, eds. Kanta Kochar- Lindgren, Davis Schneideman and Tom Denlinger (Lincoln: University of Nebraska Press, 2009). 
58 Japanese haiku verse, originating in the seventeenth century, is composed of three phrases, each of which needs to contain a specified number of phonetic units (in combination of five-seven-five). It normally consists of a juxtaposition of two different scenes and a resolution between them.

59 Alain Virmaux and Odette Virmaux, La Constellation surréaliste (Lyon: La Manufacture, 1988).

60 Nagoya-shi Bijutsukan, Nihon no shūrurearisumu: 1925-1945, 127.

61 Yamada, Ei-Kyū, 161-162.

62 Hitoshi Nara, Inexorable Modernity: Japan's Grappling with Modernity in the Arts (Lanham, MD: Lexington Books, 2007), 84-85.

63 Yamada, Ei-Kyū, 156.

64 Ōtani Shōgo, Gekidōki no avangyarudo: Shururearisumu to Nihon no kaiga 1928-1953 [Avant-Garde in Turbulent Times: Surrealism and Japanese Painting, 1928-1953] (Tokyo: Kokusho Kankōkai, 2016), 265-266.

65 Ei-Kyū et al., Hikari no kaseki: Ei-Kyū to fotoguramu no sekai [Fossilization, Imprinted Light: Ei-Kyū and Photogram Images] exh. Cat. (Urawa: Saitama Kenritsu Kindai Bijutsukan, 1997), 100.

66 Ming Tiampo, Gutai: Decentering Modernism (Chicago: University of Chicago Press, 2011), 41.

67 Yumiko lida, Rethinking Identity in Modern Japan: Nationalism as Aesthetics (London: Routledge, 2002), 18-20. The 'Fundamentals' were sold in 2 million copies, significantly outreaching its initial print of 300,000, as per Ibid., 20.

68 Ernst H. Kantorowicz, The King's Two Bodies: A Study in Mediaeval Political Theology (Princeton, NJ: Princeton University Press, 1957).

69 Edward James, 'La chapeau du people et les chapeaux de la Reine', Minotaure 9 (1936): 54-59.

70 Alastair Brotchie, 'Introduction', in Encyclopedia Acephalica, ed. Georges Bataille, assembled by Alastair Brotchie (London: Atlas Press, 1995), 12.

71 Ōtani, Gekidōki no avangyarudo, 268-270.

72 Gilles Deleuze, Francis Bacon: The Logic of Sensation, translated and with an introduction by Daniel Warren Smith, afterword by Tom Clark Conley (Minneapolis: University of Minnesota Press, 2004), 20.

73 lbid., 20-21.

74 Joyce Cheng, 'Mask, Mimicry, Metamorphosis: Roger Caillois, Walter Benjamin and Surrealism in the 1930s', Modernism/Modernity 16, no. 1 (2009): 61-86.

75 Alicia Volk, 'Authority, Autonomy, and the early Taishō "Avant-Garde"', positions: east asia cultures critique 21, no. 2 (2013): 451-473.

76 lbid., 453.

77 Ibid., 469.

78 Takeba, 'The Age of Modernism', 150.

79 'Naniwa shashinten zadankai' [Symposium on the Occasion of the Naniwa Photography Exhibition], Foto taimusu 15, no. 9 (1938): 27.

80 Nishimura, Nihon geijutsu shashinshi, 281. 
81 Krauss, 'Grids', 58-60.

82 Hanawa Gingo, 'Shashinga ni okeru zen'eiteki sakufū: Ōsaka no aru shashin kurabu reikai ni te hanasu' [Avant-Garde Style in Photography, Discussion from a Regular Meeting of an Osaka Photo Club], Foto taimusu 15, no. 5 (1938): 26.

83 Ibid.

84 Hanawa's mention is earlier than in Yamanaka's 'New Photo Collage', as in Hanawa Gingo, 'Shashinga ni okeru chōgenjitsushugi no hatten' [Development of Surrealism in the Photographic Image], Foto taimusu 15, no. 4 (1938): 32.

85 Nagoya-shi Bijutsukan, Nihon no shūrurearisumu: 1925-1945, 96.

86 Ibid., 144. Abe's interest in Surrealism can be traced back to around the age of twenty, after his artistic debut in 1932, as in Hamada Mayumi, 'Senzen no Abe Nobuo (Yoshifumi) no katsudō: Takiguchi Shūzō to no kankei o chūshin ni' [Abe Nobuo's (Yoshifumi) Prewar Activities: Focus on the Relationship with Takiguchi Shūzō], Niigata Kenritsu Kindai Bijutsukan kenkyū kiyō [Bulletin of the Niigata Prefectural Museum of Modern Art] 9 (2010): 10.

87 Nagata Isshū and Takiguchi Shūzō, 'Yume to jinsei oyobi sono tegami' [Dream and Life, Correspondence], Foto taimusu 15, no. 7 (1938): 82-84.

88 Ibid., 83.

89 Ibid., 84.

90 Nagata was active in the proletarian arts movement both as a writer and an artist and was imprisoned together with Murayama Tomoyoshi, as per Gennifer Weisenfeld, MAVO: Japanese Artists and the Avant-Garde 1905-1931 (Berkeley: University of California Press, 2010), 252.

91 Gérard de Nerval, Aurélia and Other Writings, translated by Robert Duncan and Marc Lowenthal (Boston: Exact Change, 1996), 3.

92 Breton, Manifestoes of Surrealism, 25.

93 Breton, What Is Surrealism?, 204.

94 lbid.

95 Nerval, Aurélia and Other Writings, 73-114.

96 Takiguchi also suggests that the image shows a single body with three heads, as per Nagata and Takiguchi, 'Yume to jinsei', 84.

97 In Japanese public baths, wet towels are often worn on heads to optimize the heat of the body.

98 Nagoya-shi Bijutsukan, Nihon no shürurearisumu: 1925-1945, 156.

99 Abe Yoshifumi, 'Yama no shashin' [Photographing Mountains], in Korekushon Nihon shūrurearisumu 3: Shūrurearisumu no shashin to hihyō [Collection of Surrealism in Japan 3: Surrealist Photography and Criticism], ed. Takeba Jō (Tokyo: Hon no Tomosha, 2001).

\section{Chapter 3}

1 'Les Artistes D'Avant-Garde', Atorie 14, no. 6 (1937): unpaginated. The volume is titled in Japanese as 'Zen'ei kaiga no kenkyū to hihan'. 
2 In April 1937, Kitao exhibited for the first time the photographic works that he was developing since his studies in Germany at a joint exhibition with Ei-Kyū, following their collaboration in Miyazaki since around 1934. He went on to also exhibit at the first exhibition of the Free Artists' Association in 1937, same as Ei-Kyū, becoming a full member of the group in 1938, as in Nagoya-shi Bijutsukan, Nihon no shürurearisumu: 1925-1945, 166.

3 Namigata, Ekkyō no avangyarudo, 55.

4 A number of sources confirm this characteristic of the exhibition, including a pamphlet printed by Nagoya's Shin Aichi shinbun, a sponsor of the show in the city. The pamphlet is held at the Scottish National Gallery of Modern Art.

5 Yamada Satoshi, 'Foto-abangyarudo no dōkō' [Tendency of a Photo Avant-Garde], in Nihon no shūrurearisumu: 1925-1945 [Surrealism in Japan: 1925-1945], ed. Nagoyashi Bijutsukan, exh. cat. (Nagoya: Nihon no Shūrurearisumuten Jikkō linkai, 1990).

6 Takiguchi Shūzō, 'Shashin to chōgenjitsushugi' [Photography and Surrealism], Foto taimusu 15, no. 2 (1938): 50-55.

7 Ibid. The genealogy of Surrealist photography is traced back in the article to Atget. The medium is described as playing a significant role in Breton's novels Nadja and L'Amour fou as well as in Surrealist publications such as Minotaure. Bellmer, Brassaï, Dora Maar and Man Ray are singled out as photographers working in the closest relation to Surrealism.

8 Takeba, 'The Age of Modernism', note 10, 150. For the original text, published in the January 1934 issue of Photo Times, see Takiguchi Shūzō, 'Ujeinu Atoje' [Eugène Atget], in Korekushon Takiguchi Shüzō 11, Senzen senchū hen I: 1926-1936 [Collection Takiguchi Shūzō 11, Prewar and War Period 1, 1926-1936] (Tokyo: Misuzu Shobō, 1991).

9 Takiguchi Shūzō, 'Shashin to kaiga no kōryū' [Interchange between Photography and Painting], Foto taimusu 15, no. 5 (1938): 30-37.

10 I rely on a translation of this phrase, as per Takeba, 'The Age of Modernism', 150.

11 For one such example from Takiguchi's immediate circle, see Imai Shigeru, 'Shururearizumu foto ni tai suru oboegaki' [Surrealist Photography Memorandum], Foto taimusu 15, no. 10 (1938): 51-55.

12 Hanawa, 'Shashinga ni okeru chōgenjitsushugi no hatten', 30-35.

13 Ibid., 30-32.

14 lbid., 34.

15 Dépaysement is referred to in a loanword as depeizuman and in Japanese translation as tenchihō (transposition), as in Ibid.

16 Ibid., 35.

17 Ibid., 32.

18 To some extent the relationship was also theorized by Surrealist painters. Writing in the October issue of Shashin bunka, Fukuzawa adopts a much more positive view of the relationship between photography and painting in general terms and does not see any difference in the use of individual artistic mediums for the practice of Surrealism, as in Fukuzawa Ichirō, 'Shashin no chōgenjitsushugi' [Photographic Surrealism], in Korekushon Nihon shürurearisumu 3: Shürurearisumu no shashin to hihyō [Collection of Surrealism in Japan 3: Surrealist Photography and Criticism], ed. Takeba Jō (Tokyo: Hon no Tomosha, 2001). 
19 John Clark, 'Surrealism in Japan', in Surrealism: Revolution by Night, ed. Michael Lloyd, Ted Gott and Christopher Chapman, exh. cat. (Canberra: National Gallery of Australia, 1993), 210.

20 Ibid., 207.

21 'Zen'ei shashin zadankai' [Avant-Garde Photography Symposium], Foto taimusu 15, no. 9 (1938): 8.

22 Ibid., 8-9.

23 lbid., 14-17.

24 Nakajima Tokuhiro, 'Shashin no "radikarusa"' ['Radicalism' in Photography], in Yasui Nakaji shashinshū [Nakaji Yasui Photographer 1903-1942], ed. Yasui Nakaji et al. (Tokyo: Kyōdo Tsūshinsha, 2004), 243.

25 Takiguchi Shūzō, Letter to Roland Penrose, 23 December 1938. Written in English and held at the Scottish National Gallery of Modern Art Archive.

26 Ibid.

27 Ibid.

28 A separate discussion of the exhibition of the Tanpei club among the members of the Tokyo club (Abe, Nagata, Takiguchi) is included in the same volume.

29 Hanawa Gingo, 'Seibutsu shashinga no shinhatten' [New Developments in Photographic Images of Still Life], in Korekushon Nihon shürurearisumu 3: Shūrurearisumu no shashin to hihyō [Collection of Surrealism in Japan 3: Surrealist Photography and Criticism], ed. Takeba Jō (Tokyo: Hon no Tomosha, 2001).

30 Mitsuda Yuri, 'Yasui Nakaji riarusa no hate - shashin ōgonki no kyojin' [Yasui Nakaji, the End of Reality - Giant of Photography's Golden Age], in Yasui Nakaji shashinshū [Nakaji Yasui Photographer 1903-1942], ed. Yasui Nakaji et al. (Tokyo: Kyōdo Tsūshinsha, 2004), 14-15.

31 Ibid., 15.

32 Ibid., 15.

33 lizawa Kōtarō, 'Dōjidaijin to shite no Yasui Nakaji' [Nakaji Yasui: A Contemporary], translated by Tomoko Kozaki, in Yasui Nakaji shashin sakuhinshū [The Photography of Nakaji Yasui], ed. Yasui Nakaji, lizawa Kōtarō and Kaneko Ryūichi (Tokyo: Kokusho Kankōkai, 2005), 7.

34 Mitsuda, 'Yasui Nakaji', 16.

35 Hanawa, 'Seibutsu shashinga', 218. The article also mentions other locations of joint shooting sessions - the beach and the editing desk - and includes the total of sixteen images, mostly by Japanese photographers.

36 Ibid., 221.

37 Ibid., 222.

38 Breton, Manifestoes, 255-278.

39 Ibid., 277-278.

40 For Imai, it was the best image in the show and for Takiguchi, it revealed a clear interest in (the Surrealist) objects, as per 'Zen'ei shashin zadankai', 23.

41 Ibid., 10. 
42 Silvano Levy, 'Paul Nougé Constructing Absence', in Collective Inventions: Surrealism in Belgium, ed. Patricia Allmer and Hilde Van Gelder (Leuven: Leuven University Press, 2007), 76-79.

43 Such inability of interpretation extends to the figure seen walking away in the distance, with some likelihood that its presence was accidental.

44 Katharine Conley, 'Surrealism's Ghostly Automatic Body', Contemporary French and Francophone Studies 15, no. 3 (2011): 299.

45 As per Naniwa Shashin Kurabu kaihō [Newsletter of the Naniwa Photography Club] 1-7 (1938): 6-7. Other magazines include Kamera kurabu, Shashin saron and Shashin geppō.

46 Nakajima, 'Shashin no "radikarusa"', 240.

47 'Table of Contents', Hōmu raifu 4, no. 7 (1938): unpaginated.

48 Claire Bishop, 'Introduction: Viewers and Producers', in Participation, ed. Claire Bishop (London: Whitechapel, 2006), 12. Walter Benjamin, 'The Author as Producer: Address at the Institute for the Study of Fascism, Paris, April 27, 1934', in Selected Writings Vol. 2 Part 2: 1931-1934, ed. Michael W. Jennings, Howard Eiland and Gary Smith, translated by Rodney Livingstone and others (Cambridge, MA: Harvard University Press, 2005).

49 Bishop, 'Introduction', 11.

50 Eckersall, 'From Liminality to Ideology', 231.

51 Tezuka, Jikken Kōbō, 122-123.

52 Hanawa, 'Seibutsu shashinga', 220.

53 The album also includes Kawasaki Kametarō's Sacred Torch.

54 Hal Foster, 'Violation and Veiling in Surrealist Photography: Woman as Fetish, as Shattered Object, as Phallus', in Surrealism: Desire Unbound, ed. Jenifer Mundy et al. (Princeton, NJ: Princeton University Press, 2001), 206.

55 Hanawa, 'Seibutsu shashinga', 239.

56 Yamanaka Chirū, 'Berumeeru no ningyō gensō' [The Fantasy of Bellmer's Dolls], in Korekushon Nihon shūrurearisumu 6: Yamanka Chirū 1930 nendai no oruganaizā [Collection of Surrealism in Japan 6: Yamanaka Chirū, Organiser of the 1930s], ed. Kurosawa Yoshiteru (Tokyo: Hon no Tomosha, 1999).

57 With 'sadistic love' referred to as sadisutikku na ai, in Ibid., 442.

58 Elza Adamowicz, Surrealist Collage in Text and Image: Dissecting the Exquisite Corpse (New York: Cambridge University Press, 1998), 168.

59 Ibid., 160.

60 Ibid., 163-173.

61 Elza Adamowicz, 'Hats or Jellyfish? Andre Breton's Collages', in André Breton: The Power of Language, ed. Ramona Fotiade (Exeter: Elm Bank, 2000), 93. See also André Breton, Break of Day, translated by Mark Polizzotti and Mary Ann Caws (Lincoln: University of Nebraska Press, 1999), 48.

62 Adamowicz, Surrealist Collage, 167.

63 John W. Dover et al., The Brittle Decade: Visualizing Japan in the 1930s (Boston: MFA Publications, 2012), 23. The fascination with mannequins in photographic 
practices in 1930s Japan can be evidenced outside of the particular session, with Nakayama Iwata as a prominent example.

64 See Michael Marra, 'Coincidentia Oppositorium: The Greek Genealogies of Japan', in Essays on Japan: Between Aesthetics and Literature (Leiden: Brill, 2010).

65 Tanpei Shashin Kurabu, lizawa Kōtaro, Kaneko Ryūichi, Hikari [Light] (Tokyo: Kokusho Kankōkai, 2006), 151.

66 Yasui Nakaji, 'Shashin no hattatsu to sono geijutsuteki shosō' [Development of Photography and Its Artistic Aspects], in Korekushon Nihon shūrurearisumu 3: Shürurearisumu no shashin to hihyō [Collection of Surrealism in Japan 3: Surrealist Photography and Criticism], ed. Takeba Jō (Tokyo: Hon no Tomosha, 2001), 539. The highly politically charged atmosphere of this lecture, given in the year when Surrealists were arrested throughout the country, is described in Nakajima, 'Shashin no "radikarusa"', 245-247. This ladle-like teardrop was likely produced in postproduction of the image.

67 Steven Harris, Surrealist Art and Thought in the 1930s: Art, Politics, and the Psyche (Cambridge: Cambridge University Press, 2004), 182.

68 Dawn Ades, Dalí (New York: Thames and Hudson, 1992), 73.

69 Harris, Surrealist Art and Thought, 274.

70 Johanna Malt, Surrealist Objects of Desire: Surrealism, Fetishism, and Politics (Oxford: Oxford University Press, 2004), 85.

71 Ibid., 60.

72 Harris, Surrealist Art and Thought, 180.

73 Her name is written in Japanese as 岬洋子.

74 Hanawa Gingo, 'Mahiru no haru no yume' [Dream of Spring in Broad Daylight], Kamera kurabu 3, no. 7 (1938): 42-44.

75 Ibid., 43.

76 For example, Hanawa suggests 'a night guard on his routine inspection gets surprised to find a young girl's head stuck in the factory's chimney', as per lbid.

77 Michel Poivert, 'Les images du dehors', in La Subversion des images: surréalisme, photographie, film, ed. Quentin Bajac and Clément Chéroux, exh. cat. (Paris: Éditions du Centre Pompidou, 2009), 65.

78 Ibid.

79 The photographer is signed in the volume of the magazine as Ikemiya Seimei but no record exists of a photographer under that name. Another photograph of Misaki wearing the same attire appears in the February 1938 issue of Camera Art and the photographer is there signed as Ikemiya Seijirō.

80 The particular shadow contains another Easter egg as it directly borrows from Kurt Seligmann's artwork that Hanawa brings up as an example of the Surrealist object in 'New Developments'.

81 Hanawa, 'Shashinga ni okeru zen'eiteki sakufü', 26. The origin of this gesture is here accredited to a fellow artist Amagi Jun.

82 Matsuda Kazuko, Shururearisumu to 'te' [Surrealism and 'Hand'] (Tokyo: Suiseisha, 2006), 18-19. See also Kirsten H. Powell, 'Hands-On Surrealism', Art History 20, no. 4 (1997): 531. 
83 T.Y, 'Geijutsu to yūmoa ni kansuru nōto' [Notes concerning Art and Humour], Mizue 401, no. 7 (1938): 7-10. Takiguchi Shūzō, 'Chōgenjitsushugi no shōzō shashin: Rondon de dairyūkō' [Surrealist Portrait Photography, A Major Trend in London], Foto taimusu 15, no. 9 (1938): 35-37.

84 Ishii, '“Zen'ei” ga kagayaita kisetsu', 63.

85 Jeffrey Gilbert, 'The Modern Photography Movement in Japan', in Nihon shashin zenshū 3: Kindai shashin no gunzō [Complete Collection of Photography in Japan 3: The Modern Photography Movement in Japan], ed. Kuwahara Kineo et al. (Tokyo: Shōgakkan, 1986), 186.

86 'Sekaiichi no dokushinsha - Adorufu Hittorā' [Number One Bachelor of the World: Adolf Hitler], Foto taimusu 15, no. 4 (1938): 22.

87 '“Deutch land” no shōkai' [Introducing 'Deutschland'], Foto taimusu 15, no. 4 (1938): 56.

88 Richie, 'Foreword', xxv.

89 As per Matei Calinescu, Five Faces of Modernity: Modernism, Avant-Garde, Decadence, Kistch, Postmodernism (Durham, NC: Duke University Press, 1974), 117.

90 Eckersall, 'From Liminality to Ideology', 233-234.

91 Mitsuyo Wada-Marciano, Nippon Modern: Japanese Cinema of the 1920s and 1930s (Honolulu: University of Hawai'i Press, 2008), 13.

92 Ghislaine Wood, Surreal Things: Surrealism and Design (London: V\&A Publications, 2007), 30.

93 Esther Leslie, Hollywood Flatlands: Animation, Critical Theory and the Avant-Garde (London: Verso, 2004), 145. For the ideological mobilization of antique sculpture in Japan of that time, see Michael Lucken, 'Aphrodite dans le Soleil levant: Images de la Grèce antiques dans le Japon en guerre 1937-1945', in La Guerre et les Arts, ed. Jean Baechler (Paris, Hermann: 2018).

94 'Schönheit im Olympischen Kampf, Sekai no wakamono no shukusai! Doitsu ga tsukutta orimupikku jojishi' [Schönheit im Olympischen Kampf, Festival of World's Youth! Epic Poetry of the Olympic Games Organised by Germany], Foto taimusu 15, no. 5 (1938): 20-25.

95 Another propaganda feature run by Asahi Camera in March 1939 across six pages is relevant to note. Titled 'Hitler and Young Girls' [Hitorā to shōnen shōjō], it includes several photographs of young sympathizers of NSDAP saluting Hitler at a rally, taken by Heinrich Hoffmann.

96 Clark, 'Abstract Subjectivity', 48-50.

97 Rachael Hutchinson, Negotiating Censorship in Modern Japan (London: Routledge, 2013), 6.

\section{Chapter 4}

1 Salvador Dalí, The Collected Writings of Salvador Dalí, translated and edited by Haim Finkelstein (Cambridge: Cambridge University Press, 1998), 234-235.

2 Michael Stone-Richards, 'Failure and Community: Preliminary Questions on the Political in the Culture of Surrealism', in Surrealism, Politics and Culture, ed. Raymond Spiteri and Donald LaCoss (Burlington, VT: Ashgate, 2003), 303. 
3 Takiguchi Shūzō (trans.), 'Shururearisumu no jikken ni arawareta taishō'

(Saruvadooru Dari) [The Object as Revealed in Surrealist Experiment (Salvador Dali)], in Korekushon Takiguchi Shūzō 11, Senzen senchū hen I: 1926-1936 [Collection Takiguchi Shūzō 11, Prewar and War Period 1, 1926-1936], ed. Takiguchi Shūzō, Ōoka Makoto et al. (Tokyo: Misuzu Shobō, 1991), 415-425.

4 Takiguchi Shūzō, 'Au Japon', Cahiers d'art 7-10 (1935): 132.

5 Ibid. The use of the 'hiding characters' (fuseji) was an established practice of self-censorship, in which black dots would hide words and phrases anticipated to cause attention from the state censors, as in Jay Rubin, Injurious to Public Morals: Writers and the Meiji State (Seattle: University of Washington Press, 1984), 29-31. For further discussion of this practice in 1930s Japan, see William O. Gardner, 'Avant-Garde Literature and the New City: Tokyo 1923-1931' (PhD diss., Stanford University, 1999), 23.

6 Breton, Manifestoes of Surrealism, 255-278.

7 Yamanaka Chirū, 'OBJET SURRÉALISTE no mondai' [The Problem of the Surrealist Object], in Korekushon Nihon shürurearisumu 6: Yamanaka Chirū, 1930 nendai no oruganaizā [Collection of Surrealism in Japan 6: Yamanaka Chirū, Organiser of the 1930s], ed. Kurosawa Yoshiteru (Tokyo: Hon no Tomosha, 1999).

8 As: XX ni hōshi suru shururearisurmu, in Ibid., 350. The two ' $X$ ' marks are probably replacing two ideograms for the word 'revolution' in Japanese, referred to as kakumei. Yamanaka's translation of Breton's and Ėluard's L'Immaculée conception (1930), published by Bon Shoten in 1937 as Dōteijo jutai, was censored more explicitly, with pages torn from the publication.

9 Dalí, The Collected Writings, 231-234. Yamanaka, 'OBJET SURRÉALISTE', 351.

10 Yamanaka Chirū, 'Buttai no kakumei: Obuje shururearisuto no ichi' [Object Revolution: Position of the Surrealist Object], in Korekushon Nihon shūrurearisumu 6: Yamanaka Chirū, 1930 nendai no oruganaizā [Collection of Surrealism in Japan 6: Yamanaka Chirū, Organiser of the 1930s], ed. Kurosawa Yoshiteru (Tokyo: Hon no Tomosha, 1999).

11 Ibid., 388-389. For the first part of the text that Yamanaka translated, see Dalí, The Collected Writings, 231-232.

12 Ibid., 392. This argument echoes Breton's 'Crisis of the Object' (1936), as per Breton, Surrealism and Painting, 276.

13 The images were all featured in the Cahiers d'art in 1935 and 1936 editions, with the only exception of Bellmer's work titled as Composition (Konpojishon) that is not included in these two volumes.

14 Yamanaka Chirū, 'Cheko ni okeru futari no gaka' [Two Czech Painters], in Korekushon Nihon shūrurearisumu 6: Yamanaka Chirū, 1930 nendai no oruganaizā [Collection of Surrealism in Japan 6: Yamanaka Chirū, Organiser of the 1930s], ed. Kurosawa Yoshiteru (Tokyo: Hon no Tomosha, 1999).

15 Ibid., 397. As per Breton, What Is Surrealism?, 226.

16 Ibid.

17 In former Yugoslavia, for instance, where communist tendencies were under similar suppression during the 1930s, the very mention of the word 'revolution' would result in confiscation of the entire run of the publication, as per Dejan Sretenović, 
Urnebesni Kliker: Umetnost i Politika Beogradskog Nadrealizma [The Frenzied Marble: Art and Politics of Belgrade Surrealism] (Belgrade: Službeni glasnik, 2016), 202. The comparison with Belgrade group is here pertinent, as it uniquely stopped functioning in 1932 for the stronger support for Aragonian over Bretonian tendency.

18 Harris, Surrealist Art and Thought in the 1930s, 138.

19 Ibid., 143-155.

20 Simon Baker, 'Psychologie des Foules: Surrealism and the Impossible Object', in Sculpture and Psychoanalysis, ed. Brandon Taylor (Burlington, VT: Ashgate, 2006), 46.

21 Ibid, 45.

22 Dalí, The Collected Writings, 235.

23 Shimozato Yoshio, 'Niko no tēma ni yorite' [Two Themes], in Korekushon Nihon shūrurearisumu 14: Ei-Kyū, Shimozato Yoshio, renzu no avangyarudo [Collection of Surrealism in Japan 14: Ei-Kyū, Shimozato Yoshio, Avant-Garde of the Lens], ed. Yamada Satoshi (Tokyo: Hon no Tomosha, 2001).

24 Ibid., 260.

25 lida, Rethinking Identity in Modern Japan, 23.

26 Shimozato, 'Niko no tēma', 260.

27 Takiguchi Shūzō, 'Buttai to shashin tokuni shururearisumu no obuje ni tsuite' [Object and Photography, Especially the Surrealist Object], Foto taimusu 15, no. 8 (1938): 64.

28 Ibid., 66. The categories listed include natural, savage, mathematical, found, disaster, readymade, mobile and symbolical objects.

29 Ibid., 68. Takiguchi tells a story of how Paul Nash reused as an object a sail of the Britannia yacht purchased at an auction by Nan Kivell. As in Yamanaka's previous article, images in Takiguchi's text are also sourced from the 1936 issue of Cahiers d'art (for Man Ray and Eileen Agar) but also include two Nash's photographs.

30 Ibid.

31 Morita Hajime, 'Obujekō tenbyōfū ni' [A Sketch for Thoughts about Objects], in Nihon Obuje 1920-1970 nendai danshō [Japanese Object, Fragments of the Decades between 1920-1970], ed. Morita Hajime et al., exh. cat. (Tokyo: Bijutsukan Renraku Kyōgikai, 2012), 27.

32 In 'New Developments' (September 1938), for instance, Hanawa refers the reader with more interest in the Surrealist object to Takiguchi's article as a text of crucial importance, as in Hanawa, 'Seibutsu shashinga no shinhatten', 221.

33 Koishi Kiyoshi, 'Kamikōchi kamera kikō' [Record of a Camera Trip to Kamikōchi], Foto taimusu 15, no. 10 (1938): 44-50.

34 Fire Mountain, Nagata's later rendition of one of Abe's photographs is discussed in Chapter 2.

35 Comparison to Nash's practice becomes more pressing here, as the photographs are compellingly similar to the artist's collection published in 1946 as the Monster Field. Nash had 'discovered' two enormous elm trees uprooted by lightning while visiting friends in Gloucestershire in June 1938, only a month before the excursion took place. The Monster Field, not shown or exhibited prior to October 1940, might have been informed by the Czech Surrealists Štyrský and Toyen, who showed works inspired by natural objects at the Surrealist exhibition in London in 1936, as in Walker, 
So Exotic, So Homemade, 25. Yamanaka's article on the two Czech artists from March 1937 also includes four untitled reproductions of their work, two per each artist, as in Yamanaka, 'Cheko ni okeru futari no gaka'. For two of these photographs, see also Vítézslav Nezval, 'Strysky.Toyen', Cahiers d'art 7-10 (1935): 135.

36 Abe Yoshifumi, 'Obuje no aru Yakedake' [Object Potential of Mount Yake], Foto taimusu 15, no. 10 (1938): 39.

37 Ibid., 41.

38 Ibid., 42.

39 Walter Benjamin, 'Small History of Photography', in On Photography, edited and translated by Esther Leslie (London: Reaktion Books, 2016). Roger Rothman, Tiny Surrealism: Salvador Dali and the Aesthetics of the Small (Lincoln: University of Nebraska Press, 2012), 45.

40 Abe Yoshifumi, 'Zen'eiteki hōkō e no ichikōsatsu' [A Study in Avant-Garde Methods], Foto taimusu 15, no. 7 (1938): 62. The article is dated 25 May 1938, and therefore precedes the excursion to Mount Yake but the image was likely added after the initial submission of the text.

41 Ibid., 63.

42 Abe Yoshifumi, 'Zen'eiteki hōkō hito e no ichikōsatsu, 60 pēji no tsuzuki' [A Study in Avant-Garde Methods, Continuing from Page 60], Foto taimusu 15, no. 7 (1938): 105.

43 'Zen'ei shashin saikentō zadankai' [Round Table Meeting Rethinking Avant-Garde Photography], Kameraman, February Edition (1939): 17-29.

44 Ibid., 18.

45 Ibid.

46 Ibid., 20. Sakata supports his arguments with different examples, illustrations of which also accompany the text: photographs by Moholy-Nagy, Man Ray and himself as showing 'pure' abstraction and by Dora Maar, Raul Ubac, Bellmer, Ei-Kyū and himself as indicating a 'pure Surrealist practice and Freudianism'. Reproductions of Dali's Suburbs of a Paranoiac-Critical Town: Afternoon on the Outskirts of European History (1935) and Mondrian's Composition (1921) also accompany the text.

47 Ibid., 19-20.

48 Sakata Minoru, Kashokuteki dōbutsuteki na deido [Edible, Animal Mud], Foto taimusu 16, no. 2 (1939): unpaginated.

49 'Zen'ei shashin', 21. The passage reads: 'The way I think about the two is that they are psychologically completely opposite. Abstraction elevates all its components to the level of plasticity whereas Surrealism observes everything psychologically. They appear to me as the West and the East. However, as Yamanaka observed earlier, they are surprisingly easily fused within an artwork. Truthfully speaking, I have not thought about this more deeply than that; on the contrary, it comes very easy that an abstract form reveals a psychological content in my work. Reality is like that as well.'

50 Dalí, The Collected Writings, 193-200. Dalí suggests an animate character of Art Nouveau architecture by juxtaposing photographic details of Hector Guimard's buildings with captions reading 'Eat me!'. 
51 'Surrealist psychology means Freud's psychoanalysis. It requires thinking about objects (mono) in a Freudian manner', as in 'Zen'ei shashin', 21.

52 lbid.

53 lbid., 22.

54 lbid.

55 lbid., 23.

56 Ibid.

57 lbid., 24.

58 lbid., 30.

59 The conversation indicates that the images were also viewed at the meeting, together with volumes of the Abstraction-Création magazine.

60 Dalí describes four stages through which the Surrealist object evolved: "1. The object exists outside us, without our taking part in it; 2 . The object assumes the immovable shape of our desire and acts upon our contemplation; 3 . The object is movable and such that it can be acted upon; 4. The object tends to bring about our fusion with it and makes us pursue the formation of a unity with it,' as in Dalí, The Collected Writings, 243-244.

61 'Zen'ei shashin', 27.

62 Ibid.

63 Ibid.

64 lbid., 27.

65 Ibid.

66 In the notes accompanying a reprinted version of this text, the editor blames the moderators for expressing their own views too frequently and not leading the discussion to a more conclusive end, as per Yamada Satoshi (ed.), Korekushon Nihon shūrurearisumu 14: Ei-Kyū, Shimozato Yoshio, renzu no avangyarudo [Collection of Surrealism in Japan 14: Ei-Kyū, Shimozato Yoshio, Avant-Garde of the Lens] (Tokyo: Hon no Tomosha, 2001), 316.

67 'Zen'ei shashin', 24.

68 Interestingly, Koishi reports that Sakata also had an intention of joining them on the excursion, only to be withheld at the last moment, as per Koishi, 'Kamikōchi kamera kikō', 55.

69 The same conceptual coding of Surrealist terminology includes the very term 'Surrealism', often addressed in the texts of the time in an abbreviated form shüru from the loanword shūrurearizumu. Such reworking of the word can be understood in comparison to a wide application of the word 'surreal' in English. However, in Japanese, the word shüru does not have a different meaning but indicates a more intimate, personal relationship with a word of a foreign origin to a Japanese reader, as in Akasegawa Genpei and Minami Shinbō, 'Chōgenjitsushugiteki konnyaku mondō' [Questions and Answers about Surrealist konnyaku Foodstuff], Geijutsu shinchō, February Edition (2011): 58.

70 Stone-Richards, 'Failure and Community', 318.

71 lida, Rethinking Identity in Modern Japan, 59. 
72 Ibid., 65.

73 Kohara Masashi (ed.), Fuji genkei: Kindai Nihon to Fuji no yama [Visions of Fuji: An Incurable Malady of Modern Japan], exh. cat. (Nagaizumi-chō, Shizuoka-ken: Izu Photo Museum, 2011). As this exhibition affirmed, the mountain was ascribed with different symbolic values throughout the twentieth century.

74 This collaboration is described in detail in Shimozato's diary notes, as per Yamada, Korekushon Nihon shürurearisumu 14, 307-308.

75 Shimozato Yoshio, Mesemu zoku: Chōgenjitsushugi shashin shū [Mesemb Genus, Collection of Surrealist Photographs] (Nagoya: Self-published, 1940), unpaginated. I discuss the relationship between the austere layout of the volume and the Surrealist preference for a similar type of scientific publications in Jelena Stojkovic, 'Systematic Confusion and the Total Discredit of the World of Reality: Surrealism and Photography in Japan of the 1930s', in Minor Photography: Connecting Deleuze and Guattari to Photography Theory, ed. Mieke Bleyen (Leuven: Leuven University Press, 2012), 177.

76 For translation of this section of the book, refer to Jelena Stojkovic, 'Language of Light: Legacy of Surrealism in 1930s Japanese Photography' (MA diss., School of Oriental and African Studies, University of London, 2009).

77 Shimozato, Mesemu zoku, unpaginated.

$78 \mathrm{lbid}$. In terms of the enlarged size of the cactus, he asserts how it is not unusual to him, as he has seen it as such in his dreams many times.

79 Shimozato makes sure to especially thank Sakata in the commentary, as per Ibid.

80 Georges Bataille, Visions of Excess: Selected Writings, 1927-1939, translated by Allan Stoekl (Minneapolis: University of Minnesota Press, 1985), 14.

81 Dawn Ades, 'Little Things: Close-Up in Photo and Film 1839-1963', in Close-Up: Proximity and Defamiliarization in Art, Film and Photography, ed. Dawn Ades and Simon Baker, exh. cat. (Edinburgh: Fruitmarket Gallery, 2008), 32.

82 Elza Adamowicz, 'Exquisite Excrement: The Bataille-Breton Polemic', Aurifex 2 (2003): unpaginated.

83 Ibid.

84 Diary note made in November 1936, as in Yamada, Korekushon Nihon shürurearisumu 14, 306. The only natural objects in this issue of the magazine that could be regarded as related to Shimozato's project in formalist terms are found objects collected by Ernst, resembling some of the later shots of the Mesemb, such as $A$ Balloon.

85 Shimozato Yoshio, 'L''art non-figuratif” kaisetsu' [Explanation of 'NonFigurative Art'], in Korekushon Nihon shūrurearisumu 14: Ei-Kyū, Shimozato Yoshio, renzu no avangyarudo [Collection of Surrealism in Japan 14: Ei-Kyū, Shimozato Yoshio, Avant-Garde of the Lens], ed. Yamada Satoshi (Tokyo: Hon no Tomosha, 2001).

86 lbid., 255.

87 lbid.

88 Shimozato Yoshio, 'Chūshōha no tenkai: Shūrureyarisumu to no kōryū ni tsuite' [Development of Abstraction, Exchange with Surrealism], in Korekushon Nihon 
shūrurearisumu 14: Ei-Kyū, Shimozato Yoshio, renzu no avangyarudo [Collection of Surrealism in Japan 14: Ei-Kyū, Shimozato Yoshio, Avant-Garde of the Lens], ed. Yamada Satoshi (Tokyo: Hon no Tomosha, 2001), 257.

$89 \mathrm{lbid}, 257$. Okamoto wrote about his life in Paris during the 1930s on many occasions. For a detailed description of the period, see Okamoto Tarō, 'Pari no nakama tachi' [Paris Friends], in Okamoto Tarō chosakushū, 2: Kuroi Taiyō [Okamoto Tarō Collection, 2: Dark Sun] (Tokyo: Kōdansha, 1980). According to this text, he was the youngest member of the Abstraction-Création when he joined the group aged twenty-one in 1932, three years after his arrival to Paris. In the same text he recounts his admiration for and a close friendship with Arp, as well as anecdotes involving Victor Brauner and Leonor Fini, among others. At the time of the letter, Okamoto had already been more inclined towards Surrealism for several years.

90 Briony Fer, On Abstract Art (New Haven, CT: Yale University Press, 1997), 59.

91 Walter Benjamin, 'Letter from Paris [2]: Painting and Photography', in Walter Benjamin, Selected Writings, Volume 3, 1935-1938, ed. Howard Eiland and Michael W. Jennings, translated by Edmund Japhcott, Howard Eiland, and Others (Cambridge, MA: Belknap Press of Harvard University Press, 2002), 243.

92 Shimozato Yoshio, 'Chōgenjitsu kaiga to sutairu' [Surrealist Painting and Style], in Korekushon Nihon shürurearisumu 14: Ei-Kyū, Shimozato Yoshio, renzu no avangyarudo [Collection of Surrealism in Japan 14: Ei-Kyū, Shimozato Yoshio, Avant-Garde of the Lens], ed. Yamada Satoshi (Tokyo: Hon no Tomosha, 2001).

93 Shimozato describes the style developed by Dalí as 'photographic' and gives examples of abstraction as embraced by such artists as Miró, Arp and Tanguy in Ibid. For his study of the specific artists, together with Magritte, see Shimozato Yoshio, 'Chōgenjitsu kaiga no hōhō' [Methods in Surrealist Painting], in Korekushon Nihon shürurearisumu 14: Ei Kyū, Shimozato Yoshio, renzu no avangyarudo [Collection of Surrealism in Japan 14: Ei Kyū, Shimozato Yoshio, Avant-Garde of the Lens], ed. Yamada Satoshi (Tokyo: Hon no Tomosha, 2001).

94 Tsukahara Fumi, Setsudan suru bigaku: Avangyarudo geijutsu shisōshi [Cutting Edge Avant-Garde - History of Thought of Avant-Garde Art] (Tokyo: Ronsōsha, 2013), 301-303.

95 Takiguchi Shūzō, 'Shokubutsu no kiroku' [Recording Plants], Foto taimusu 16, no. 1 (1939): 57-61.

96 Shimozato makes a diary note that he has a meeting with Takiguchi in this regard on 15 March 1939, as per Yamada, Korekushon Nihon shürurearisumu 14, 309.

97 Takiguchi Shūzō, 'Shimozato Yoshio hencho "Mesemu zoku” ni tsuite' [Mesemb Genus, Authored and Edited by Shimozato Yoshio], in Korekushon Nihon shūrurearisumu 14: Ei-Kyū, Shimozato Yoshio, renzu no avangyarudo [Collection of Surrealism in Japan 14: Ei-Kyū, Shimozato Yoshio, Avant-Garde of the Lens], ed. Yamada Satoshi (Tokyo: Hon no Tomosha, 2001), 253.

98 lbid.

99 Takiguchi Shūzō, 'Nazo no sōzōsha: Sarubadōru Dari' [Salvador Dali, Creator of Riddles], in Korekushon Takiguchi Shūzō 13, Senzen senchū hen III: 1939-1944 [Collection Takiguchi Shūzō 13, Prewar and War Period 3, 1939-1944], ed. Takiguchi Shūzõ, Ōoka Makoto et al. (Tokyo: Misuzu Shobō, 1995). 
100 Ōtani Shōgo and Yamada Satoshi, '1930 nendai Dari būmu no shinsō, Taidan: Yamada Satoshi x Ōtani Shōgo' [The Truth about the Dalí Boom in the 1930s, Cross Talk: Yamada Satoshi x Ōtani Shōgo], Bijutsu techō 68, no. 1043 (October 2016): 80-85.

101 Shogo Otani, 'Dreams of the Horizon - Introduction', translated by Ogawa Kikuko, in Chiheisen no yume: Shōwa 10 nendai no gensō kaiga [Dreams of the Horizon: Fantastic Paintings in Japan 1935-1945], ed. Tokyō Kokuritsu Kindai Bijutsukan, Ōtani Shōgo, exh. cat. (Tokyo: Tōkyō Kokuritsu Kindai Bijutsukan, 2003), 21.

102 Rothman, Tiny Surrealism, 56-62.

103 I rely on Ogawa's translation of this paragraph, as per Otani, 'Dreams of the Horizon', 20.

104 Ibid., 22.

105 Ibid., 23.

106 Shimozato, Mesemu zoku, unpaginated. The size of the album is $46.2 \times 32.8 \mathrm{~cm}$. 107 lbid.

\section{Chapter 5}

1 The navy and the air forces had their separate artistic collectives. For a detailed overview, see Maki Kaneko, 'New Art Collectives in the Service of the War: The Formation of Art Organizations during the Asia-Pacific War', positions: east asia cultures critique 21, no. 2 (2013): 309-350.

2 Yoshihara Jirō et al., Yoshihara Jirō ten: Seitan 100 nen kinen [Jirō Yoshihara: A Centenary Retrospective] exh. cat. (Tokyo: Asahi Shinbunsha, 2005), 109.

3 'Shashin Zōkei Kenkyūkai ni tsuite: Photo Experiment Group' [Photo Plasticity Research Association: Photo Experiment Group], Foto taimusu 16, no. 4 (1939): 28.

4 Roxana Marcoci et al., The Original Copy: Photography of Sculpture, 1839 to Today, exh. cat. (New York: New York Museum of Modern Art, 2010), 11.

5 'Shashin Zōkei Kenkyūkai ni tsuite', 333.

6 Takiguchi Shūzō (trans.), 'Kindai zōkei geijutsu (Jiideion Uerukaa)' [Modern Plastic Art (Carola Giedion-Welcker)], in Takiguchi Shūzō, Ōoka Makoto et al., Korekushon Takiguchi Shūzō 12, Senzen senchū hen II: 1937-1938 [Collection Takiguchi Shūzō 12, Prewar and War Period 2, 1937-1939] (Tokyo: Misuzu Shobō, 1993).

7 ibid., 207.

8 Takeba Jō explains the word to be inspired by its use in Bauhaus, but not having an exact equivalent in English as it stands for 'any manner of image creation' that was 'free of the dangerous, foreign connotations of both avant-garde and Surrealism' at the time, as in Takeba, 'The Age of Modernism', 153.

9 Takiguchi Shūzō, 'Zōkei shashin kōenkai no kiroku yori' [Report on a Lecture about Plastic Photography], Foto taimusu 16, no. 5 (1939): 95.

10 Ibid., 93.

11 Ibid., 95. 
12 Jean Laplanche and Jean-Bertrand Pontalis, The Language of Psychoanalysis (New York: W.W. Norton, 1973), 317-318.

13 Takiguchi, 'Zōkei shashin kōenkai', 95. For a definition of fantasy as a 'matter of staging', see Victor Burgin, 'Fantasy', in Feminism and Psychoanalysis: A Critical Dictionary, ed. Elizabeth Wright (Oxford: Blackwell, 1992), 85.

14 Takiguchi, 'Zōkei shashin kōenkai', 95.

15 Ibid.

16 Ibid.

17 Takiguchi Shūzō (trans.), 'Foto Montaaju (Baabara Moogan)' [Photomontage (Barbara Morgan)], in Takiguchi Shūzō, Ōoka Makoto et al., Korekushon Takiguchi Shūzō 13, Senzen senchū hen III: 1939-1944 [Collection Takiguchi Shūzō 13, Prewar and War Period 3, 1939-1944] (Tokyo: Misuzu Shobō, 1995).

18 Takiguchi Shūzō, 'Jikkenteki shashinka to shite no Mohori Nagii' [Moholy-Nagy, An Experimental Photographer], Foto taimusu 15, no. 9 (1938): 41-48. For a later text, see Takiguchi Shūzō, 'Zōkei kunren to shashin' [Training in Plasticity and Photography], in Takiguchi Shūzō, Ōoka Makoto et al., Korekushon Takiguchi Shūzō 13, Senzen senchū hen III: 1939-1944 [Collection Takiguchi Shūzō 13, Prewar and War Period 3, 1939-1944] (Tokyo: Misuzu Shobō, 1995).

19 Takiguchi Shūzō, 'Mohori Nagii kara no tegami sono ta' [A Letter from Moholy-Nagy and Other], Foto taimusu 17, no. 1 (1940): 22-23.

20 Takiguchi, 'Zōkei shashin kōenkai', 95.

21 Sakata Minoru, 'Foto abusutorakushon to Foto shururearizumu' (1-3), [Photo Abstraction and Photo Surrealism (1-3)], in Korekushon Nihon shūrurearisumu 3:

Shürurearisumu no shashin to hihyō [Collection of Surrealism in Japan 3: Surrealist Photography and Criticism], ed. Takeba Jō (Tokyo: Hon no Tomosha, 2001). See also Sakata Minoru, 'Foto abusutorakushon to Foto shururearizumu' (4) [Photo Abstraction and Photo Surrealism (4)], Shashin geppō, March Edition (1938): 45-51.

22 Sakata, 'Foto abusutorakushon to Foto shururearizumu' (1-3) 115.

23 Sakata Minoru, Zōkei shashin 1934-1941: Sakata Minoru sakuhinshū [Structure in Photography: Minoru Sakata's Anthology] (Nagoya: Arumu, 1988), 164.

24 Sakata Minoru, "'Chōgenjitsushugi shashin" [fotoshūrearisumu] to "Chūshōzōei" [fotoabusutorakushon] no gutaiteki na kaisetsu 1, 2' [A Basic Explanation of 'Photo-Surrealism' and 'Photo-Abstraction' 1, 2], in Korekushon Nihon shūrurearisumu 3: Shūrurearisumu no shashin to hihyō [Collection of Surrealism in Japan 3: Surrealist Photography and Criticism], ed. Takeba Jō (Tokyo: Hon no Tomosha, 2001).

25 Ibid., 351.

26 Ibid., 355-356.

27 Ibid., 357-358.

28 Ibid. Sakata makes the same comment at the Nagoya meeting, as per 'Zen'ei shashin', 20.

29 Ibid., 359-360.

30 Ibid., 360. 
31 Vilém Flusser's notion of 'technical images' is a significant force in the contemporary photographic discourse in this sense. See, for instance, Vilém Flusser, Towards a Philosophy of Photography (London: Reaktion, 2014).

32 In his study of abstract photography Lyle Rexer identifies exactly the same modes of practice as crucial: Lyle Rexer, The Edge of Vision: The Rise of Abstraction in Photography (New York: Aperture, 2009), 9.

33 Ian Parker, Japan in Analysis: Cultures of the Unconscious (New York: Palgrave Macmillan, 2008), 27-30.

34 Ōtsuji Kenji, 'Furoido to kindai kaiga' [Freud and Modern Painting], in Korekushon Nihon shūrurearisumu 2: Shūrurearisumu no bijutsu to hihyō [Collection of Surrealism in Japan 2: Surrealist Art and Criticism], ed. Omuka Toshiharu (Tokyo: Hon no Tomosha, 2001).

35 Ibid., 132.

36 Takiguchi Shūzō, 'Furoitoshugi to gendai geijutsu' [Freudianism and Contemporary Art], in Takiguchi Shūzō, Ōoka Makoto et al., Korekushon Takiguchi Shūzō 13, Senzen senchū hen III: 1939-1944 [Collection Takiguchi Shūzō 13, Prewar and War Period 3, 1939-1944] (Tokyo: Misuzu Shobō, 1995). Takiguchi notes how other psychoanalysts such as Pierre Janet understood unconscious to be relevant to art even before Freud, as in Ibid., 245-247.

37 Takiguchi Shūzō, 'Saruvadoru Dari no keitaigaku' [Salvador Dali's Morphology], Mizue 400 (1938): 13-16.

38 Ibid., 13-14.

39 Salvador Dalí, 'Interprétation paranoïaque-critique de l'image obsédante "L'Angélus" de Millet', Minotaure 1 (1933): 65-67. Dr Lacan, 'Le problème du style et les formes paranoïaques de l'expérience', Minotaure 1 (1933): 68-69.

40 Salvador Dalí, 'Les nouvelles coulers du sex appeal spectral', Minotaure 5 (1934): 20-21. Takiguchi writes about Minotaure in the February 1935 issue of Serupan, comparing it to the earlier Documents and complementing its abundance of photographic reproductions, as per Takiguchi Shūzō, 'Minotaure', in Takiguchi Shūzō, Ōoka Makoto et al., Korekushon Takiguchi Shūzō 11, Senzen senchū hen I: 1926-1936 [Collection Takiguchi Shūzō 11, Prewar and War Period 1, 1926-1936] (Tokyo: Misuzu Shobō, 1991).

41 Takiguchi, 'Nazo no sōzōsha', 13.

42 lbid., 12.

43 Ibid., 13-15.

44 As early as in 1931, for instance, Koga Harue notes how in its unique relation to reality, Surrealism offers a mechanism for exploration of the unconscious, as in Koga Harue, 'Chōgenjitsushugi shikan' [Une approache du surréalisme], translated by Věra Linhartová, in Japon des Avant Gardes, 1910-1970: Exposition, ed. Centre Georges Pompidou, exh. cat. (Paris: Éditions du Centre Pompidou, 1986), 159.

45 Yamanaka Chirū (trans.), 'Kusatta roba (Saruvadooru Dari)' [Rotting Donkey (Salvador Dali)], Mizue 394 (1937): 13-17.

46 Yamanaka Chirū, 'Furansu kaiga no zen'ei, Sarubadoru Dari no ichi' [French Avant-Garde Painting, The Position of Salvador Dali], in Korekushon Nihon shūrurearisumu 6: Yamanaka Chirū, 1930 nendai no oruganaizā [Collection of 
Surrealism in Japan 6: Yamanaka Chirū, Organiser of the 1930s], ed. Kurosawa Yoshiteru (Tokyo: Hon no Tomosha, 1999), 348. Yamanaka does not refer to La femme visible (1930), the first compilation of Dali's texts in which the paranoiaccritical method was elaborated, but instead seems to be using Minotaure as a source literature, similar to Takiguchi.

47 Ibid. In terms of Dali's work through which the method was worked through, The Lugubrious Game was seen in Japan at the Chögenjitsushugi Kaigai Sakuhin ten in photographic reproduction, together with a sample of Dali's illustrations for the 1934 edition of Comte de Lautréamont's Le Chants de Maldoror (1868-1869).

48 Fiona Bradley, 'Dalí as a Myth-Maker: The Tragic Myth of Millet's Angelus', in Salvador Dali: A Mythology, ed. Dawn Ades and Fiona Bradley (London: Tate Gallery, 1998), 16.

49 Rothman, Tiny Surrealism, 129.

50 Ibid.

51 For how this discussion developed with regard to Dali's illustrations for the 1934 edition of Lautréamont's Le Chants de Maldoror, see David Lomas, The Haunted Self: Surrealism, Psychoanalysis, Subjectivity (New Haven, CT: Yale University Press, 2000), 163-164.

52 Dalí, The Collected Writings, 223.

53 Nagoya-shi Bijutsukan, Nihon no shūrurearisumu: 1925-1945, 145.

54 Takiguchi Shūzō, 'Kazari mado no aru tenrankai' [An Exhibition with a Show Window Potential], in Nihon no shūrurearisumu: 1925-1945 [Surrealism in Japan: 19251945], ed. Nagoya-shi Bijutsukan, exh. cat. (Nagoya: Nihon no Shūrurearisumuten Jikkō linkai, 1990).

55 lbid., 149.

56 Ibid.

57 Ades, 'Little Things', 52.

58 Brassaï and Salvador Dalí, 'Sculptures Involontaires', Minotaure 3-4 (1933): 68.

59 Simon Baker, 'Watch Out for Life: The Conceptual Close-Up 1920-1960', in CloseUp: Proximity and Defamiliarization in Art, Film and Photography, ed. Dawn Ades and Simon Baker, exh. cat. (Edinburgh: Fruitmarket Gallery, 2008), 94.

60 For an example of writing about Magritte at the time, see Takiguchi Shūzō, 'Rune Maguritto' [René Magritte], Mizue 414 (1939): 4-8.

61 Simon O'Sullivan, 'From Stuttering and Stammering to the Diagram: Towards a Minor Art Practice?', in Minor Photography: Connecting Deleuze and Guattari to Photography Theory, ed. Mieke Bleyen (Leuven: Leuven University Press, 2012), 9.

62 Ibid., 6-7.

63 lida, Rethinking Identity in Modern Japan, 43.

64 Dalí, The Collected Writings, 302-306.

65 For an example of one of such Dalís obsessions, see Salvador Dalí, The Tragic Myth of Millet's Angelus: Paranoiac-Critical Interpretation including the Myth of William Tell, translated by Eleanor R. Morse (St. Petersburg: Salvador Dali Museum, 1986), 74. 
66 Takahashi Wataru, 'Tsū kansho' [Two Impressions], Kameraman, June Edition (1938): 24-26.

67 lbid., 25.

68 Sakata, Zōkei shashin, 164.

69 For details about the exchange between the clubs in Osaka and Fukuoka, see Nakajima, 'Shashin no "radikarusa"', 243. See also Fukuoka-shi Bijutsukan (ed.), Soshiete Irufu: Kyōdo no zen'ei shashinka tachi [Avant-Garde Photographers in Fukuoka: Société Irf], exh. cat. (Fukuoka: Fukuoka-shi Bijutsukan, 1988), 4.

70 Ōtani, Dreams of the Horizon, 22. In reference to Takiguchi Shūzō, 'Fukuzawa Ichirō ron' [On Ichiro Fukuzawa], Mizue 560 (1950): 33. I rely on Ogawa Kikuko's translation of Takiguchi's quote provided in this text.

71 Ibid., 22. For such a reading of Dali's painting, see Malt, Surrealist Objects of Desire, 180-189.

72 Ōtani, Dreams of the Horizon, 26.

73 Dawn Ades, 'Dali's Optical Illusions', in Dali's Optical Illusions, ed. Dawn Ades (Hartford: Wadsworth Atheneum Museum of Art, 2000), 18.

74 lbid., 19.

75 Ibid., 20.

76 Ibid. The relevance of Bataille's notion of 'formless' in (Western) contemporary art is famously explored in Yves-Alain Bois and Rosalind Krauss (eds.), Formless: A User's Guide, exh. cat. (New York: Zone Books, 1999).

77 Inagaki Taizō, Touching and Feeling at Night and Tajima Tsugio, Bad Omen, Foto taimusu 16, no. 7 (1939): unpaginated (Yamanaka).

78 Shimozato Yoshio, Decision, Foto taimusu 16, no. 11 (1939): unpaginated (Sakata Minoru).

79 Tajima Tsugio, Beautiful Fissure, Foto taimusu 16, no. 3 (1939): unpaginated (Takiguchi Shūzō).

80 Yamanaka Chirū, 'Sakata Minoru no sakuhin' [Sakata Minoru's Artworks], Shashin saron, January Edition (1939): 48-51.

81 Ibid., 48-49. Yamanaka even stresses how those photographers who would like to practise Surrealism should 'love their cameras more', as in Ibid., 48.

82 Sakata Minoru, 'Zen'ei shashin sakuhin no gijutsuteki na kaisetsu' [The Technological Explanation of Avant-Garde Photography], Photo Times 15, no. 12 (1938): 58-64. Flowing Eyeball also accompanies this text.

83 Sakata Minoru, 'Sakuga gihō tanaoroshi chō' (1) [Inventory Notebook of a Picture Making Process], Foto taimusu 16, no. 4 (1939): 71-76. Sakata Minoru, 'Sakuga gihō tanaoroshi chō' (2) [Inventory Notebook of a Picture Making Process], Foto taimusu 16, no. 5 (1939): 55-60. Sakata Minoru, 'Sakuga gihō tanaoroshi chō' (3) [Inventory Notebook of a Picture Making Process], Foto taimusu 16, no. 7 (1939): 41-44. I discuss this body of work in detail in Jelena Stojkovic, 'Sakata Minoru's "No- Things": Photographic Plasticity in Japan (1939-1940)', in Object Fantasies, Experience and Creation, ed. Philippe Cordez, Romana Kaske, Julia Sviello and Susanne Thürigen (Berlin: Walter de Gruyter, 2018). 
84 Sakata 'Sakuga gihō tanaoroshi chō' (1), 71. See also Sakata 'Sakuga gihō tanaoroshi chō' (2), 55.

85 Sakata implies his knowledge of anamorphism by describing Surrealism as sometimes adopting 'amoeba-like form' (amībateki keitai) in 'The Technological Explanation', as per Sakata, 'Zen'ei shashin sakuhin', 295.

86 Shimozato Yoshio, 'Foto amachua kō' [Thoughts of a Photo Amateur], in Korekushon Nihon shūrurearisumu 14: Ei-Kyū, Shimozato Yoshio, renzu no avangyarudo [Collection of Surrealism in Japan 14: Ei-Kyū, Shimozato Yoshio, Avant-Garde of the Lens], ed. Yamada Satoshi (Tokyo: Hon no Tomosha, 2001).

87 lbid., 284.

88 I am grateful to Takeba Jō, curator at the Nagoya City Museum of Art, for showing me the series in May 2013.

\section{Chapter 6}

1 Dan Mitsuji, 'Sensō to shūrurearizumu sono ta' [War and Surrealism, and Else], Kamera āto, June Edition (1939): 10.

2 Nakajima Tokuhiro, 'Toshi no shashinka, Nakayama Iwata - sono shirarezaru ichimen' [lwata Nakayama, A Photographer of the Modern City - Its Unknown Aspect], in Shirarezaru Nakayama Iwata [Iwata Nakayama, His Unknown Aspects], ed.

Nakajima Tokuhiro and Takasago Miwako, exh. cat. (Tokyo: Seibu Hyakkaten, 1989), unpaginated. I use the title of the exhibition provided in English translation of the text in this volume and rely on translation of Itagaki Takaho's comment provided there.

3 Ibid. A part of the series can be viewed in Hyōgo Kenritsu Bijutsukan (ed.), Retoro modan Kōbe: Nakayama Iwata tachi ga nokoshita senzen no Kōbe [Nakayama Iwata's Retrospective: A Photographer and Prewar Kobe], exh. cat. (Kobe: Hyōgo Kenritsu Bijutsukan, 2010), 26-50.

4 Nakayama Iwata, 'Fuyu no sakuhinshū' [A Winter Collection of Artworks], Kamera kurabu 3, no. 1 (1938): unpaginated.

5 Kawahata Naomichi, 'Shashin hekiga no jidai: Pari Banpaku to Nyūyōku Banpaku Kokusaikan Nihonbu chūshin ni' [The Photomural Age: Japanese Exhibits at the Paris International Exposition and the New York World's Fair], in 'Teikoku' to bijutsu: 1930 nendai Nihon no taigai bijutsu senryaku ['Empire' and Art: Japanese Art of the 1930s and Its Strategic Expansion Abroad], ed. Omuka Toshiharu (Tokyo: Kokusho Kankōkai, 2010), 388.

6 Ibid., 408. For the photobook that accompanied the display and was distributed at the site and among the sponsors of the pavilion, see Nippon [Japan] (Tokyo: Kokusai Bunka Shinkōkai, 1937).

7 Kawahata, 'Shashin hekiga no jidai', 446.

8 John Robert Gold and Margaret M. Gold, Cities of Culture: Staging International Festivals and the Urban Agenda, 1851-2000 (Burlington, VT: Ashgate, 2005), 97. After the exhibition closed, the Japanese pavilion was destroyed in protest of the attack on Pearl Harbor. 
9 Domon Ken, 'Puropaganda' [Propaganda], Foto taimusu 16, no. 3 (1939): 11.

10 ‘Kongo no shashin wa kōde aritai: Hōdō shashin, Geijutsu shashin, Zen'ei shashin nado o chūshin ni purofesshonaru to amachua no zadankai' [The Way for Photography from Now On: A Round Table Meeting between Professionals and Amateurs, Focusing on Photojournalist, Art, Avant-Garde and Other Photography], Foto taimusu 16, no. 3 (1939): 61-69.

11 'Tairiku to shashin no zadankai' [A Round Table Discussion of the Continent and Photography], Foto taimusu 16, no. 6 (1939): 85-92.

12 Tucker, The History of Japanese Photography, 348.

13 Abe Yoshifumi, 'Dairen yori' [From Dalian], Foto taimusu 16, no. 9 (1939): 25.

14 'Tairiku kaisai Nihon shinshin shashin sakka sakuhin ten no puroguramu' TThe Continent Exhibition: Programme for an Exhibition of Artworks by Japanese Emerging Photographers], in Korekushon Nihon shūrurearisumu 3: Shūrurearisumu no shashin to hihyō [Collection of Surrealism in Japan 3: Surrealist Photography and Criticism], ed. Takeba Jō (Tokyo: Hon no Tomosha, 2001), 448. The proposed programme appears at the very end of the February 1940 volume of Photo Times, a special issue dedicated to photography on the 'continent'.

15 Abe Yoshifumi, ‘Gūgo' [Conversation], Kameraman, July Edition (1938): 21.

16 Hamada, 'Senzen no Abe Yoshifumi', 16 n. 28.

17 Takeba Jō (ed.), Korekushon Nihon shūrurearisumu 3: Shūrurearisumu no shashin to hihyō [Collection of Surrealism in Japan 3: Surrealist Photography and Criticism] (Tokyo: Hon no Tomosha, 2001), 617.

18 Abe Yoshifumi, 'Abe Yoshifumi no pēji' [Abe Yoshifumi's Page], Foto taimusu 17, no. 2 (1940): 33. This entire volume is dedicated to photography on the continent and showcases a number of local photographers. The same issue also includes Watanabe's feature, adopting a full-page format and featuring similar close-up renditions of everyday objects.

19 Namigata, Ekkyō no avangyarudo, 60.

20 Huang Ya-Li's film Le Moulin (2015) shows a similar exchange between the avantgarde circles in colonial Taiwan and Japan in the 1930s.

21 Annika Culver, Glorify the Empire: Japanese Avant-Garde Propaganda in Manchukuo (Vancouver: University of British Columbia Press, 2013), 6-7.

22 'Tairiku genchi hōkoku zadankai' [Report from the Continent Symposium], Foto taimusu 17, no. 3 (1940): 71-72.

23 Ibid., 71.

24 Culver, Glorify the Empire, 2-3.

25 Namigata, Ekkyō no avangyarudo, 67.

26 lbid., 67-68.

27 'Tairiku genchi hōkoku zadankai', 81.

28 Namigata, Ekkyō no avangyarudo, 69.

29 Ibid., 70.

30 Walter Benjamin, The Work of Art in the Age of Mechanical Reproduction, translated by J. A. Underwood (London: Penguin, 2008), 38. 
31 Alana Jelinek, This Is Not Art: Activism and Other 'Non-Art' (London: I.B. Tauris, 2013).

32 Volk, 'Authority, Autonomy', 466-467.

33 Culver, Glorify the Empire, 5. None of the photographers discussed in Culver's study - such as Fuchikami Hakuyō and Kimura Ihei - were 'avant-garde' in the Surrealist sense of the word but were working within the modernist shinkō shashin. For the most recent overview of modernist photography in Manchukuo, see Takeba Jō (ed.), Ikyō no modanizumu: Manshū shashin zenshi [The Development of Japanese Modern Photography in Manchoukuo], exh. cat. (Tokyo: Kokusho Kankōkai, 2017).

34 Kenneth Ruoff, 'Japanese Tourism to Mukden, Nanjing, and Qufu, 1938-1943', Japan Review 27 (2014): 171-200.

35 Omuka, Hijōji no modanizumu, 146-161.

36 Sakata Minoru, 'Anchishurubariarizumu to Anchiavangarito (Hizen'ei geijutsuka, Giji chōgenjitsushugi haisekiron)' [Anti-Surrvariarism and Anti-Avantgardian: A NonAvant-Garde Artist's Boycott of Pseudo-Surrealism], Kamera āto 3 (1939): 20-22.

37 Ibid., 21.

38 The mistake took place in a mixture of Japanese katakana and ideogram letters as shürubariyarizumu, whereas 'variarism' is spelled in Japanese as bariarizumu, as per Ibid.

39 Ibid.

40 Yabumae Tomoko, 'Chūshō kaiga no chinmoku: Hasegawa Saburō ni okeru "koten" to "zen'ei"' [The Silence of Abstract Painting: 'Classics' and 'Avant-Garde' in Hasegawa Saburō's Work], in Kurashikku modan: 1930 nendai Nihon no geijutsu [Classically Modern: Japanese Art in the 1930s], ed. Omuka Toshiharu and Kawata Akihisa (Tokyo: Serika Shobō, 2004), 119.

41 Hasegawa Saburō, Kyōdoshi [Chronicle of One's Native Place], in Korekushon Nihon shūrurearisumu 3: Shūrurearisumu no shashin to hihyō [Collection of Surrealism in Japan 3: Surrealist Photography and Criticism], ed. Takeba Jō (Tokyo: Hon no Tomosha, 2001).

42 Taniguchi Eri, "Kikaiteki shikaku media no "eikyō" kara miru Shōwa 10 nendai no zen'ei kaiga - Takiguchi Shūzō "Eikyō ni tsuite" (Shōwa 14 nen) o tegakari ni' [Avant-Garde Painting of the 1930s Seen from the Perspective of Mechanical Media 'Influence', in Reference to Takiguchi Shūzō's 'On Influence' (1939)], in Shōwaki bijutsu tenrankai no kenkyū: Senzenhen [Research into Art Exhibitions in Shōwa Era, Prewar Period], ed. Tōkyō Bunkazai Kenkyūjo Kikaku Jōhōbu [Tokyo National Research Institute for Cultural Properties] (Tokyo: Kokuritsu Bunkazai Kikō Tōkyō Bunkazai Kenkyūjo, 2009), 399.

43 Hasegawa, Kyōdoshi, 379. Shōji equally refers to sliding doors, windows and room partitions, and different materials are used for rectangular wooden panels.

44 For a rare account of this collaboration, see Taniguchi Eri, 'Kindai Nihonno 'zen'ei geijutsu' to media, tekunoroji' ['Avant-Garde Art', Media, and Technology in Modern Japan] (PhD diss., Tokyo University of the Arts, 2011).

45 Nagoya-shi Bijutsukan, Nihon no shūrurearisumu: 1925-1945, 200.

46 Takahashi Wataru compares the image with Mondrian's abstraction in the issue, as per Foto taimusu 16, no. 10 (1939): unpaginated. 
47 Ibid.

48 lbid.

49 Takeba Jō, 'Aru chāto e no chūshaku: Nagoya no shashinshi o meguru danshō' [Annotations on a Certain Chart: Pieces of Photography History in Nagoya], Rear 14 (2006): 10.

50 Alan Tansman (ed.), The Culture of Japanese Fascism (Durham, NC: Duke University Press, 2009).

51 Shimozato Yoshio, 'Gaizai suru hishatai ni yorite hi-shōkeiteki zōei (1)' [NonFigurative Imaging of External Objects (1)], Foto taimusu 16, no.12 (1939): 46-50. Shimozato Yoshio, 'Gaizai suru hishatai ni yorite hi-shōkeiteki zōei (2)' [NonFigurative Imaging of External Objects (2)], Foto taimusu 17, no. 1 (1940): 47-50.

52 Yamanaka Chirū, 'Shashin zōkei zuisō' [Occasional Thoughts on Plastic Photography], Foto taimusu 17, no. 7 (1940): 60-62.

53 Ibid., 61.

54 Ibid., 62.

55 According to photography historian Kaneko Ryūichi, Hirai Terushichi collaborated with the police, as discussed in a conversation with the author at the Tokyo Photographic Art Museum on 22 February 2013.

56 'Hittorā to kodomo: Hittorā wa shashin no tsuyosa to kowasa o shitteiru' [Hitler and Children: Hitler Knows the Power and Fear of Photography], Kamera kurabu 10 (1940): 12-14. A text written by a photographer and a member of the Documentary Photography Club follows the feature, describing Hitler's understanding and use of the power of photographic representation, with the work of Heinrich Hoffmann and Leni Riefenstahl as examples: Shibata Ryūji, 'Nachisu no kamera seisaku' [Nazi Camera Policies], Kamera kurabu, October Edition (1940): 15.

57 Takiguchi Shūzō, 'Shashin to zōkeisei no saikentō' [Re-Examining Photography and Plasticity], Foto taimusu 17, no. 11 (1940): 23-25.

58 Ibid., 24.

59 Ibid., 25.

60 lbid.

61 Sakata, Zōkei shashin 1934-1941, unpaginated.

62 Almost every source that offers a study of Sakata's work in the decade includes this later Yamamoto's recollection. See, for example, Nishimura, Nihon geijutsu shashinshi, 288-290.

63 lida, Rethinking Identity in Modern Japan, 36.

64 Sandra Wilson, 'Rethinking Nation and Nationalism in Japan', in Nation and Nationalism in Japan, ed. Sandra Wilson (London: Routledge, 2002), 18.

65 Sakata Minoru, 'Atarashiki waraji' [A New Pair of Straw Sandals], Kamera āto 7 (1940): 63-67, 72.

66 Ibid., 63.

67 Ibid., 65.

68 Ibid., 67.

69 Takeba, Korekushon Nihon shūrurearisumu 3, 631.

70 Takeba, 'Nagoya no shashinshi', 14. 
71 'Overcoming Modernity' (Kindai no chōkoku), a symposium organized by the Kyoto University in 1942, represents the peak of this ideology, according to which the war was both ethically and aesthetically justified. For a detailed account of this symposium, see Harry D. Harootunian, Overcome by Modernity: History, Culture, and Community in Interwar Japan (Princeton, NJ: Princeton University Press, 2002), 34-94.

72 Sakata, 'Atarashiki waraji', 67.

73 Ibid., 66.

74 Ibid., 72.

75 Hiromi Mizuno, Science for the Empire (Stanford, CA: Stanford University Press, 2009), 3.

76 lbid., 82.

77 Takiguchi, 'Shashin to zōkeisei', 24.

78 Yamamoto was interrogated by the police with regard to publishing the Surrealist magazine Yoru no funsui (1938-1939) in 1939, with the police asking him such questions as 'How does your surreal photography aid Japan's war efforts?', as per Solt, 'Perception, Misperception, Nonperception', 53.

79 Sakata Minoru, Shashin no zōkei bunka e no hōshi, Zōkei shashin no seikaku [Photography in the Service of Plastic Culture, Characteristics of Plastic Photography] (Tokyo: Arusu, 1941).

80 Ibid., 7.

81 lbid., 8.

82 lbid., 13.

83 Ibid., 31.

84 Ibid., 34.

85 Ibid., 45. Mizuno, Science for the Empire, 83.

86 Harry Harootunian, 'Constitutive Ambiguities: The Persistence of Modernism and Fascism in Japan's Modern History', in The Culture of Japanese Fascism, ed. Alan Tansman (Durham, NC: Duke University Press, 2009), 81.

87 Yamamoto Kansuke, 'Garan no densetsu' [Buddhist Legend], in Korekushon Nihon shūrurearisumu 3: Shūrurearisumu no shashin to hihyō [Collection of Surrealism in Japan 3: Surrealist Photography and Criticism], ed. Takeba Jō (Tokyo: Hon no Tomosha, 2001).

88 Maddox, 'Disobedient Spirit', 200-201. See also Munro, Communicating Vessels, 153-154.

89 Yamamoto Kansuke, 'Shashin ni kansuru kanketsu na zōgon' [A Concise Vilification with Regard to Photography], in Korekushon Nihon shürurearisumu 3: Shūrurearisumu no shashin to hihyō [Collection of Surrealism in Japan 3: Surrealist Photography and Criticism], ed. Takeba Jō (Tokyo: Hon no Tomosha, 2001). Although Yamamoto published poetry in the magazine since its establishment in 1935, he only started submitting photographs in 1939, when he became a member of the VOU Club (VOU Kurabu), an association behind the publication led by a Surrealist poet, Kitasono Katsue, as in Sawa, Korekushon, Toshi modanizumu shishi 15, 632-633.

90 Yamamoto, 'Shashin ni kansuru', 521. 
91 Ibid., 521.

92 lbid., 523.

93 Takiguchi Shūzō, 'Dari no kinkyō' [Dalîs Recent Activities], in Takiguchi Shūzō, Ōoka Makoto et al., Korekushon Takiguchi Shūzō 13, Senzen, senchūhen III: 1939-1944 [Collection Takiguchi Shūzō 13, Prewar and War Period 3, 1939-1944] (Tokyo: Misuzu Shobō, 1995).

94 Ibid., 134.

95 Takiguchi Shūzō, 'Futatsu no pōtorēto' [Two Portraits], in Takiguchi Shūzō, Ōoka Makoto et al., Korekushon Takiguchi Shūzō 13, Senzen, senchūhen III: 1939-1944 [Collection Takiguchi Shūzō 13, Prewar and War Period 3, 1939-1944] (Tokyo: Misuzu Shobō, 1995).

96 Takiguchi Shūzō, 'Amerika ni watatta Dari' [Dalí Goes to America], in Takiguchi Shūzō, Ōoka Makoto et al., Korekushon Takiguchi Shūzō 13, Senzen, senchūhen III: 1939-1944 [Collection Takiguchi Shūzō 13, Prewar and War Period 3, 19391944] (Tokyo: Misuzu Shobō, 1995).

97 Ibid., 138.

98 Ibid., 139. For a detailed discussion of Enigma of Hitler, see Robin Greeley, 'Dali's Fascism, Lacan's Paranoia', Art History 24, no. 4 (2001): 477.

99 Sawa, Korekushon, Toshi modanizumu shishi 15, 766.

100 For a detailed discussion about the incident in 1934 in which Dalí was accused for 'glorification of Hitlerian fascism', see Ades, Dalí, 106-107.

101 Mark Polizzotti, Revolution of the Mind: The Life of André Breton (Boston: Black Widow Press, 2009), 435.

102 Michael Lucken, 'Total Unity in the Mirror of Art', translated by Francesca Simkin, in Art and War in Japan and Its Empire, ed. Asato Ikeda, Aya L. McDonald and Ming Tiampo (Leiden: Brill, 2013), 80.

103 Isamu Noguchi and Ansel Adams are some of the prominent figures in the United States who opposed to this decision and showed their support by volunteering at and documenting the camps.

104 Matsumi, Kōkoku shashin no modanizumu, 54.

105 Lucken, 'Total Unity', 80-81.

106 Ibid., 83-84.

107 Mizuno, Science for the Empire, 11.

\section{Conclusion}

1 Miwako Tezuka, 'Jikken Kōbō and Takiguchi Shūzō: The New Deal Collectivism of 1950s Japan', positions: east asia cultures critique 21, no. 2 (2013): 355-357.

2 Mitsuda Yuri, 'Nihon "gendai bijutsu" no seiritsu to tenkai' [The Establishment and Development of 'Contemporary Art' in Japan], in Bijutsu no Nihon kingendaishi: Seido, gensetsu, zōkei [Histories of Modern and Contemporary Japan through Art: Institutions, Discourses, Practice], ed. Kitazawa Noriaki, Satō Dōshin and Mori Hitoshi (Tokyo: Tokyō Bijutsu, 2014), 531. 
3 Eikoh Hosoe and Mark Holborn, Eikoh Hosoe: Masters of Photography (New York: Aperture, 1999), 1.

4 Yuri Mitsuda, 'The Realism Debate', in Doryun Chong et al., From Postwar to Postmodern: Art in Japan 1945-1989, Primary Documents (New York: Museum of Modern Art, 2012), 49.

5 Kotarō lizawa, 'The Evolution of Postwar Photography', in Anne Wilkes Tucker et al., The History of Japanese Photography (New Haven, CT: Yale University Press, 2003), 213.

6 Satomi Fujimura, 'The "First" Avant-Garde', in The Japanese Photobook, 19121990, ed. Manfred Heiting and Kaneko Ryuichi (Göttingen: Steidl, 2017), 101.

7 Tsuchiya Seiichi, 'Midasareta "kiroku" no arika: "Shashin hyaku nen" saikō' [The Whereabouts of the 'Record' Discovered: Reflections on A Century of Photography], translator unknown, in Nihon shashin no 1968: 1966-1974 Futtō suru shashin no mure [1968, Japanese Photography: Photographs that Stirred Up Debate, 1966-1974], ed. Tokkyō-to Shashin Bijutsukan, exh. cat. (Tokyo: Tōkyō-to Shashin Bijutsukan, 2013), XVIII.

8 Yuri Mitsuda, "Intersections of Art and Photography in 1970s Japan: "Thinking from Dates and Places"', translated by Reiko Tomii, in For a New World to Come: Experiments in Japanese Art and Photography, 1968-1979, ed. Nakamori Yasafumi, exh. cat. (Houston: Museum of Fine Art Houston, 2015), 28.

9 Mitsuda, 'Nihon "gendai bijutsu"', 529-530.

10 lbid., 535-536.

11 Tezuka, 'Jikken Kōbō and Takiguchi Shūzō', 359.

12 Ōtsuji Kiyoji, Shashin nōto [Note of Photography] (Tokyo: Bijutsu Shuppansha, 1989), 142-147.

13 Ōtsuji Kiyoji et al., Ōtsuji Kiyoji no shashin: Deai to koraborēshon [Ōtsuji Kiyoji's Photography: Encounters and Collaborations] (Tokyo: Firumu Âto sha, 2007), 10.

14 Abe's collaboration with Ōtsuji followed the resuming of his activities in the photographic 'world' in 1949, as per lizawa Kōtarō, 'Shashinkai e no ekkyōsha, Abe Nobuya to shashin' [Beyond the Borders of the Photography World: Abe Nobuya and Photography], in Abe Nobuya: Akunaki ekkyōsha [Nobuya Abe 1913-1971: Insatiable Quest beyond Borders], ed. Shioda Jun'ichi et al., exh. cat. (Tokyo: Inshōsha, 2018), 15.

15 Yamaguchi Katsuhiro, '"Jikken Kōbō" to bijutsu no datsu-ryōiki' [Experimental Workshop and the Deterritorialization of Art], translator unknown, in Omāju Takiguchi Shūzō ten 11: Jikken Kōbō to Takiguchi Shūzō = Experimental Workshop [Homage Exhibition to Takiguchi Shūzō 11: Jikken Kōbō and Takiguchi Shūzō = Experimental Workshop], ed. Satani Garō, exh. cat. (Tokyo: Satani Garō, 1991), 26.

16 Mizusawa Tsutomu, ‘Jikken Kōbō: Mebae to kizashi' [Experimental Workshop: A Seeding and a Sign], translated by Polly Barton, in Jikken Kōbō ten: Sengo geijutsu o kirihiraku [Experimental Workshop: Opening Up Postwar Art], ed. Kanagawa kenritsu kindai bijutsukan, exh. cat. (Tokyo: Yomiuri Shinbunsha, 2013), 314. For the collaboration between Hamada and Ōtsuji, see Kurosawa Yoshiteru, Nihon no shururearisumu to iu shikōya [Japanese Surrealism, a Field of Thought] (Tokyo: Meibun Shobō, 2016), 421-425.

17 lbid. 
18 Ibid., 312.

19 Mitsuda, 'Nihon "gendai bijutsu"', 550.

20 Ibid., 551. Hasegawa delivered a lecture at the Columbia University in 1954, in a series of talks on Zen Buddhism.

21 Miwako Tezuka, 'Experimentation and Tradition: The Avant-Garde Play Peirrot Lunaire by Jikken Kōbō and Takechi Tetsuji', Art Journal 70, no. 3 (2011): 68.

22 Mitsuda, 'Nihon "gendai bijutsu"', 551.

23 Pedro Erber, 'Introduction to Akasegawa Genpei's "The Object after Stalin"', ARTMargins 4, no. 3 (2015): 110.

24 Reiko Tomii, Radicalism in the Wilderness, International Contemporaneity and 1960 s Art in Japan (Cambridge, MA: MIT Press, 2016), 35.

25 Ibid., 37.

26 Iwaya Kunio, 'Takiguchi Shūzō to Andore Buruton' [Shuzo Takiguchi and André Breton], translator unknown, in Omāju Takiguchi Shūzō ten 13: Andore Buruton to Takiguchi Shūzō [André Breton and Shuzo Takiguchi: The 13th Exhibition Homage to Shuzo Takiguchi], ed. Satani Garō, exh. cat. (Tokyo: Satani Garō, 1993), 45.

27 Thomas R. H. Havens, Radicals and Realists in the Japanese Nonverbal Arts (Honolulu: University of Hawaii Press, 2006), 51.

28 Ross, Photography for Everyone, 41-68.

29 'Joryū sakka ni teigen suru' [Recommendations to Women Artists], Photo Times 17, no. 4 (1940): 6-11. Takiguchi Shūzō, 'Dōra Māru' [Dora Maar], Photo Times 17, no. 4 (1940): 22-23. Lee Miller is also accredited in the historical account of women photographers included at the end of the volume.

30 Kokatsu Reiko and Yoshimoto Midori (eds.), Zen'ei no josei, 1950-1975 [Japanese Women Artists in Avant-Garde Movements, 1950-1975] (Utsunomiya-shi: Tochigi Kenritsu Bijutsukan, 2005). See also Alicia Volk, 'Katsura Yuki and the Japanese Avant-Garde', Woman's Art Journal 24, no. 2 (2004): 3-9.

31 Ikeda Tatsuo, 'Watashi ni totte shururearisumu to wa nani ka: Sono shiteki na shishiteki na hōkoku' The Way I See Surrealism, a Private and Personal Historical Report], Bijutsu techō 336 (1970): 154-161.

32 Isozaki Arata, "Han-kaisō: "Ore wa hyōronka janakute hihyōka nan da" to itta Tōno Yoshiaki no koto o omoidashite mita' [Anti-Recollection: Trying to Recall Tōno Yoshiaki, Who Said: 'I am Not a Commentator, I am a Critic'], in Kyozō no jidai: Tōno Yoshiaki bijutsu hihyōsen [Art Critics by Yoshiaki Tono], ed. Tōno Yoshiaki, Matsui Shigeru and Imura Yasuko (Tokyo: Kawade Shobō Shinsha, 2013).

33 William A. Marotti, Money, Trains and Guillotines: Art and Revolution in 1960s Japan (Durham, NC: Duke University Press, 2013), 127. Marotti gives an example of Kaidō Hideo, a collaborator of Takiguchi's in Surrealist research groups during the 1930s, who was among the chief initiators of the Yomiuri Indépendant. A major annual exhibition running from 1949 and possibly the most significant platform for the rise of independent and alternative art in Japan, it also showed the work of such Surrealist artists as Ernst in 1951, as per Ei-Kyū, Ei-Kyū Sakuhinshū [Ei-Kyū, Compilation of Artworks] (Tokyo: Nihon Keizai Shinbunsha, 1997), 13.

34 Marotti, Money, Trains and Guillotines, 179. 
35 Ibid., 180.

36 Ibid., 161.

37 Takiguchi Shūzō, Kindai geijutsu [Modern Art] (Tokyo: Bijutsu Shuppansha, 1962), 12.

38 Ibid., 14.

39 Ibid., 8.

40 Durozoi, History of the Surrealist Movement, 532-533. Maurice Blanchot, 'Reflections on Surrealism', in The Work of Fire, translated by Charlotte Mandell (Stanford, CA: Stanford University Press, 1995), 85.

41 Durozoi, History of the Surrealist Movement, 461-481. Agnieszka Kuczuńska, 'Surréalism en 1947 - Occultism and the Post-War Marginalisation of Surrealism', Art Inquiry. Recherches sur les arts 16 (2014): 87-99.

42 Scott J. Miller, Historical Dictionary of Modern Japanese Literature and Theatre (Lanham, MD: Scarecrow Press, 2009), 111.

43 KuroDalaiJee, 'Performance Collectives in 1960s Japan: With a Focus on the "Ritual School", positions: east asia cultures critique 21, no. 2 (2013): 430.

44 lbid., 429-430.

45 lbid., 431.

46 Nonaka's collages accompany several books of Shibusawa's writing, including Kyō-ō, Rütovihi ni- sei ('Mad King' Ludwig II, 1966).

47 Iwaya Kunio, 'Shururearisumu no kyō: Sono "kakuri" to "inpei” ni tsuite' [Today of Surrealism, and Its 'Isolation' and 'Concealment'], Bijutsu techō 336 (1970): 49. 


\section{BIBLIOGRAPHY}

Abe Yoshifumi. 'Abe Yoshifumi no pēji' [Abe Yoshifumi's Page]. Foto taimusu 17, no. 2 (1940): 33.

Abe Yoshifumi. 'Dairen yori' [From Dalian]. Foto taimusu 16, no. 9 (1939): 25.

Abe Yoshifumi. 'Gūgo' [Conversation]. Kameraman, July Edition (1938): 21.

Abe Yoshifumi. 'Obuje no aru Yakedake' [Object Potential of Mount Yake]. Foto taimusu 15, no. 10 (1938): 39-43.

Abe Yoshifumi. 'Tairiku kaisai Nihon shinshin shashin sakka sakuhin ten no puroguramu' [The Continent Exhibition: Programme for an Exhibition of Artworks by Japanese Emerging Photographers]. In Korekushon Nihon shūrurearisumu 3: Shūrurearisumu no shashin to hihyō [Collection of Surrealism in Japan 3: Surrealist Photography and Criticism], edited by Takeba Jō, 448. Tokyo: Hon no Tomosha, 2001.

Abe Yoshifumi. 'Yama no shashin' [Photographing Mountains]. In Korekushon Nihon shūrurearisumu 3: Shūrurearisumu no shashin to hihyō [Collection of Surrealism in Japan 3: Surrealist Photography and Criticism], edited by Takeba Jō, 483-485. Tokyo: Hon no Tomosha, 2001.

Abe Yoshifumi. 'Zen'eiteki hōkō e no ichikōsatsu' [A Study in Avant-Garde Methods]. Foto taimusu 15, no. 7 (1938): 60-63.

Abe Yoshifumi. 'Zen'eiteki hōkō hito e no ichikōsatsu, 60 pēji no tsuzuki' [A Study in

Avant-Garde Methods, Continuing from Page 60]. Foto taimusu 15, no. 7 (1938): 105.

Adachi Gen. 'Puroretaria bijutsu no shōchō: Kakumei no sensō no tame no bijutsu'

[The Prosperity and Decay of Proletarian Art: Artistic Practice for the Revolutionary War]. In Bijutsu no Nihon kingendaishi: Seido, gensetsu, zōkei [Histories of Modern and Contemporary Japan through Art: Institutions, Discourses, Practice], edited by Kitazawa Noriaki, Satō Dōshin and Mori Hitoshi, 285-326. Tokyo: Tōkyō Bijutsu, 2014.

Adachi Gen. Zen'ei no idenshi: Anakizumu kara sengo bijutsu e [Memes of the Japanese Avant-Garde: From Anarchism to Postwar Art]. Kunitachi: Buryukke, 2012.

Adamowicz, Elza. 'Exquisite Excrement: The Bataille-Breton Polemic'. Aurifex 2 (2003).

Adamowicz, Elza. 'Hats or Jellyfish? Andre Breton's Collages'. In André Breton: The Power of Language, edited by Ramona Fotiade, 83-95. Exeter: Elm Bank, 2000.

Adamowicz, Elza. Surrealist Collage in Text and Image: Dissecting the Exquisite Corpse. New York: Cambridge University Press, 1998.

Ades, Dawn. Dalí. New York: Thames and Hudson, 1992.

Ades, Dawn. 'Dali's Optical Illusions'. In Dali's Optical Illusions, edited by Dawn Ades, 10-29. Hartford, CT: Wadsworth Atheneum Museum of Art, 2000.

Ades, Dawn. 'Little Things: Close-Up in Photo and Film 1839-1963'. In Close-Up: Proximity and Defamiliarization in Art, Film and Photography, edited by Dawn Ades and Simon Baker, 9-59. Exhibition catalogue. Edinburgh: Frutimarket Gallery, 2008. 
Akasegawa Genpei and Minami Shinbō. 'Chōgenjitsushugiteki konnyaku mondō' [Questions and Answers about Surrealist konnyaku Foodstuff]. Geijutsu shinchō, February Edition (2011): 56-73.

Allmer, Patricia. Lee Miller: Photography, Surrealism, and Beyond. Manchester: Manchester University Press, 2016.

Aoki Shigeru and Tōkyō Kokuritsu Bunkazai Kenkyūjōo (eds). Kindai Nihon āto katarogu korekushon 73: Jiyū Bijutsu Kyōkai, Bijutsu Sōsakka Kyōkai [Collection of Modernist Japanese Art Catalogues Vol. 73: Free Artists' Association and Art Creatives' Association]. Tokyo: Yumani Shobō, 2004.

Aragon, Louis. 'The Challenge to Painting'. In The Surrealists Look at Art, edited by Pontus Hulten, 47-74. Venice, CA: Lapis Press, 1990.

Ashiya Shiritsu Bijutsu Hakubutsukan (ed.). Ashiya Kamera Kurabu 1930-1942: Ashiya no bijutsu o saguru [Ashiya Camera Club 1930-1942: Exploring the Beauty of Ashiya]. Ashiya: Ashiya Shiritsu Bijutsu Hakubutsukan, 1998.

Atorie (editorial). 'Chōgenjitsushugi hihan' [Criticising Surrealism]. In Korekushon Nihon shūrurearisumu 15: Shūrurearisumu kihon shiryō shūsei [Collection of Surrealism in Japan 15: Surrealism, Collection of Fundamental Documents], edited by Wada Hirofumi, 94-103. Tokyo: Hon no Tomosha, 2001.

Bäckström, Per and Benedikt Hjartarson (eds). Decentring the Avant-Garde. Amsterdam: Rodopi, 2014.

Bajac, Quentin, et al. 'Changer la vue'. In La Subversion des images: surréalisme, photographie, film, edited by Quentin Bajac and Clément Chéroux, 17-19. Exhibition catalogue. Paris: Édicion du Centre Pompidou, 2009.

Baker, Simon. 'Psychologie des Foules: Surrealism and the Impossible Object'. In Sculpture and Psychoanalysis, edited by Brandon Taylor, 33-51. Burlington, VT: Ashgate, 2006.

Baker, Simon. 'Watch Out for Life: The Conceptual Close-Up 1920-1960'. In Close-Up: Proximity and Defamiliarization in Art, Film and Photography, edited by Dawn Ades and Simon Baker, 61-105. Exhibition catalogue. Edinburgh: Fruitmarket Gallery, 2008.

Barthes, Roland. Camera Lucida: Reflections on Photography. Translated by Richard Howard. London: Vintage Books, 2000.

Bataille, Georges. Visions of Excess: Selected Writings, 1927-1939. Translated by Allan Stoekl. Minneapolis: University of Minnesota Press, 1985.

Bate, David. 'Introduction'. History of Photography 29, no. 2 (2015): 97-98.

Bate, David. Photography and Surrealism: Sexuality, Colonialism and Social Dissent. London: I.B. Tauris, 2003.

Beckmann, George M. and James W. Morley. Dilemmas of Growth in Prewar Japan. Princeton, NJ: Princeton University Press, 1974.

Benjamin, Walter. 'The Author as Producer: Address at the Institute for the Study of Fascism, Paris, April 27, 1934'. In Walter Benjamin, Selected Writings Vol. 2 Part 2: 1931-1934, edited by Michael W. Jennings, Howard Eiland and Gary Smith, translated by Rodney Livingstone and Others, 768-782. Cambridge, MA: Harvard University Press, 1999.

Benjamin, Walter. 'Letter from Paris [2]: Painting and Photography'. In Walter Benjamin, Selected Writings, Volume 3, 1935-1938, edited by Howard Eiland and Michael W. Jennings, translated by Edmund Japhcott, Howard Eiland and Others, 236-248. Cambridge, MA: Harvard University Press, 2002.

Benjamin, Walter. 'Small History of Photography'. In On Photography, edited and translated by Esther Leslie, 99-174. London: Reaktion Books, 2016. 
Benjamin, Walter. The Work of Art in the Age of Mechanical Reproduction. Translated by J.A. Underwood. London: Penguin, 2008.

Bishop, Claire. 'Introduction: Viewers and Producers'. In Participation, edited by Claire Bishop, 10-17. London: Whitechapel, 2006.

Blanchot, Maurice. 'Reflections on Surrealism'. In The Work of Fire, translated by Charlotte Mandell, 85-97. Stanford, CA: Stanford University Press, 1995.

Bois, Yves-Alain and Rosalind Krauss (eds). Formless: A User's Guide. Exhibition catalogue. New York: Zone Books, 1999.

Brassaï and Salvador Dalí. 'Sculptures Involontaires'. Minotaure 3-4 (1933): 68.

Bradley, Fiona. 'Dalí as a Myth-Maker: The Tragic Myth of Millet's Angelus'. In Salvador Dali: A Mythology, edited by Dawn Ades and Fiona Bradley, 12-31. London: Tate Gallery, 1998.

Breton, André. Break of Day. Translated by Mark Polizzotti and Mary Ann Caws. Lincoln: University of Nebraska Press, 1999.

Breton, André. Manifestoes of Surrealism. Translated by Richard Seaver and Helen Lange. Ann Arbor: University of Michigan Press, 1974.

Breton, André. Surrealism and Painting. Translated by Simon Watson Taylor. New York: Monad, 1972.

Breton, André. What Is Surrealism? Selected Writings. Edited and introduced by Franklin Rosemot. New York: Pathfinder, 2012.

Breton, André and Paul Éluard. Dictionnaire abrégé du surréalisme. Exhibition catalogue. Paris: Galerie Beaux-Arts, 1938.

Bober, Harry. 'The Zodiacal Miniature of the Très Riches Heures of the Duke of Berry Its Sources and Meaning'. Journal of the Warburg and Courtauld Institutes 11 (1948): 1-34.

Brotchie, Alastair. 'Introduction'. In Encyclopedia Acephalica, edited by Georges Bataille, assembled by Alastair Brotchie, 7-28. London: Atlas Press, 1995.

Burgin, Victor. 'Fantasy'. In Feminism and Psychoanalysis: A Critical Dictionary, edited by Elizabeth Wright, 84-88. Oxford: Blackwell, 1992.

Calinescu, Matei. Five Faces of Modernity: Modernism, Avant-Garde, Decadence, Kistch, Postmodernism. Durham, NC: Duke University Press, 1974.

Chadwick, Whitney. 'An Infinite Play of Empty Mirrors: Women, Surrealism, and SelfRepresentation'. In Mirror Images: Women, Surrealism, and Self- Representation, edited by Whitney Chadwick, 2-35. Cambridge, MA: MIT Press, 1998.

Clark, John. 'Surrealism in Japan'. In Surrealism: Revolution by Night, edited by Michael Lloyd, Ted Gott and Christopher Chapman, 204-213. Exhibition catalogue. Canberra: National Gallery of Australia, 1993.

Clark, John. 'Abstract Subjectivity in the Taisho and Early Showa Avant-Garde'. In Japanese Art after 1945: Scream against the Sky, edited by Alexandra Munroe, 41-53. Exhibition catalogue. New York: H.N. Abrams, 1994.

Clark, John. Modern Asian Art. Honolulu: University of Hawaii Press, 1998.

Clark, John. Surrealism in Japan. Clayton, VIC: Monash Asia Institute, Japanese Studies Centre, 1997.

Cheng, Joyce. 'Mask, Mimicry, Metamorphosis: Roger Caillois, Walter Benjamin and Surrealism in the 1930s'. Modernism/Modernity 16, no. 1 (2009): 61-86.

Chéroux, Clément. 'The Avant-Garde of Amateurs'. In Photography: A New Vision of the World 1891-1940, edited by Gerry Badger and Walter Guadagnini, 14-29. Milan: Skira, 2012. 
Conley, Katharine. 'Surrealism's Ghostly Automatic Body'. Contemporary French and Francophone Studies 15, no. 3 (2011): 297-304.

Culver, Annika. Glorify the Empire: Japanese Avant-Garde Propaganda in Manchukuo. Vancouver: University of British Columbia Press, 2013.

Dalí, Salvador. The Collected Writings of Salvador Dalí. Translated and edited by Haim Finkelstein. Cambridge: Cambridge University Press, 1998.

Dalí, Salvador. 'Interprétation paranoïaque-critique de l'image obsédante "L’Angélus" de Millet'. Minotaure 1 (1933): 65-67.

Dalí, Salvador. 'Les nouvelles coulers du sex appeal spectral'. Minotaure 5 (1934): 20-21.

Dalí, Salvador. 'Photography: Pure Creation of the Mind'. In The Sources of Surrealism: Art in Context, edited by Neil Matheson, 371-373. Aldershot: Lund Humphries, 2006.

Dalí, Salvador. The Tragic Myth of Millet's Angelus: Paranoiac-Critical Interpretation including the Myth of William Tell. Translated by Eleanor R. Morse. St. Petersburg: Salvador Dali Museum.

Dan Mitsuji. 'Sensō to shūrurearizumu sono ta' [War and Surrealism, and Else]. Kamera āto, June Edition (1939): 10-11.

Deleuze, Gilles. Francis Bacon: The Logic of Sensation. Translated and with an introduction by Daniel Warren Smith. Afterword by Tom Clark Conley. Minneapolis: University of Minnesota Press, 2004.

“'Deutch land” no shōkai' [Introducing 'Deutschland']. Foto taimusu 15, no. 4 (1938): 56.

Domon Ken. 'Puropaganda' [Propaganda]. Foto taimusu 16, no. 3 (1939): 11.

Dover, John W., et al. The Brittle Decade: Visualizing Japan in the 1930s. Boston: MFA Publications, 2012.

Durozoi, Gérard. History of the Surrealist Movement. Translated by Alison Anderson. Chicago: University of Chicago Press, 2009.

Eckersall, Peter. 'From Liminality to Ideology: The Politics of Embodiment in Prewar Avant-Garde Theatre in Japan'. In Not the Other Avant-Garde, edited by James Harding and John Rouse, 225-249. Ann Arbor: University of Michigan Press, 2006.

Ei-Kyū. Ei-Kyū Sakuhinshū [Ei-Kyū, Compilation of Artworks]. Tokyo: Nihon Keizai Shinbunsha, 1997.

Ei-Kyū. 'Gendai seikatsu to hikari to kage to: Foto dessan no sakusha to shite no kansō' [Modern Life, Light and Shadow: Impressions of a Photo-Drawing's Creator]. Hōmu raifu 2, no. 8 (1936): 28.

Ei-Kyū. 'Genjitsu ni tsuite' [On Reality]. Atorie 14, no. 6 (1937): 71-74.

Ei-Kyū, et al. Hikari no kaseki: Ei-Kyū to fotoguramu no sekai [Fossilization, Imprinted Light: Ei-Kyū and Photogram Images]. Exhibition catalogue. Urawa: Saitama Kenritsu Kindai Bijutsukan, 1997.

Erber, Pedro. 'Introduction to Akasegawa Genpei's "The Object after Stalin"'. ARTMargins 4, no. 3 (2015): 103-114.

Faber, Monika, et al. Das Innere der Sicht: Surrealistische Fotografie der 30er und 40er Jahre: Ausstellungskatalog. Vienna: Osterreichisches Fotoarchiv, 1989.

Fer, Briony. On Abstract Art. New Haven, CT: Yale University Press, 1997.

Foucault, Michel. This Is Not a Pipe. Berkeley: University of California Press, 1983.

Fijalkowski, Krzysztof. 'Invention, Imagination, Interpretation: Collective Activity in the Contemporary Czech and Slovak Surrealist Group'. Papers of Surrealism 3 (Spring 2005): 1-14. 
Fijalkowski, Krzystof, Michael Richardson and lan Walker. Surrealism and Photography in Czechoslovakia: On the Needles of Days. London: Routledge, 2016.

Finkelstein, Haim. 'Screen and Layered Depth: Surrealist Painting and the Conceptualization of the Mental Space'. Res: Anthropology and Aesthetics 51 (2007): 183-201.

Finkelstein, Haim. The Screen in Surrealist Art and Thought. Burlington, VT: Ashgate, 2007. Flusser, Vilém. Towards a Philosophy of Photography. London: Reaktion Books, 2014. Foster, Hal. 'Violation and Veiling in Surrealist Photography: Woman as Fetish, as Shattered Object, as Phallus'. In Jenifer Mundy et al., Surrealism: Desire Unbound, 203-226. Princeton, NJ: Princeton University Press, 2001.

Freud, Sigmund. The Interpretation of Dreams. Translated by Joyce Crick. Introduction and notes by Richie Robertson. Oxford: Oxford University Press, 1999.

Fujimura, Satomi. 'The "First" Avant-Garde'. In The Japanese Photobook, 1912-1990, edited by Manfred Heiting and Kaneko Ryuichi, 99-101. Göttingen: Steidl, 2017.

Fujimura Satomi. 'Korāju to fotomontāju: Shashin reimeiki no fotomontāju kara Nihon no shashin ni okeru korāju no juyō made' [Collage and Photomontage: From Photomontage at the Dawn of Age of Photography to Reception of Collage in Japanese Photography], Tōkyō-to Shashin Bijutsukan, Kiyō [The Bulletin: Tokyo Metropolitan Museum of Photography] 6 (2007): 28-38.

Fujimura Satomi. 'Shinkō shashin to wa nandatta no ka' [What Was New Photography]. In Kōga to shinkō shashin: Modanizumu no Nihon [The Magazine and the New Photography: KOGA and Japanese Modernism], edited by Tokyō-to Shashin Bijutsukan, 198-201. Exhibition catalogue. Tokyo: Kokusho Kankōkai, 2018.

Fukuoka-shi Bijutsukan (ed.). Soshiete Irufu: Kyōdo no zen'ei shashinka tachi [AvantGarde Photographers in Fukuoka: Société Irf]. Exhibition catalogue. Fukuoka: Fukuoka-shi Bijutsukan, 1988.

Fukuzawa Ichirō. 'Shashin no chōgenjitsushugi' [Photographic Surrealism]. In Korekushon Nihon shūrurearisumu 3: Shürurearisumu no shashin to hihyō [Collection of Surrealism in Japan 3: Surrealist Photography and Criticism], edited by Takeba Jō, 271-283. Tokyo: Hon no Tomosha, 2001.

Garbagna, Cristina. Collages: From Cubism to New Dada. Milan: Electa, 2007.

Gardner, William O. 'Avant-Garde Literature and the New City: Tokyo 1923-1931'. PhD dissertation, Stanford University, 1999.

Gardner, William O. 'New Perceptions: Kinugasa Teinosuke's Films and Japanese Modernism'. Cinema Journal 43, no. 3 (2004): 59-78.

Gascoyne, David. 'Introduction'. In André Breton, Paul Éluard and Philippe Soupault, The Automatic Message; The Magnetic Fields; The Immaculate Conception. Translated by David Gascoyne, Antony Melville and Jon Graham. Introduced by David Gascoyne and Antony Melville, 39-54. London: Atlas Press, 1997.

Gilbert, Jeffrey. 'The Modern Photography Movement in Japan'. In Kuwahara Kineo et al., Nihon shashin zenshū 3: Kindai shashin no gunzō [Complete Collection of Photography in Japan 3: The Modern Photography Movement in Japan], 185-187. Tokyo: Shōgakkan, 1986.

Gold, John R. and Margaret M. Gold. Cities of Culture: Staging International Festivals and the Urban Agenda, 1851-2000. Burlington, VT: Ashgate, 2005.

Greeley, Robin. 'Dali's Fascism, Lacan's Paranoia'. Art History 24, no. 4 (2001): 465-492.

Gunma Kenritsu Tatebayashi Bijutsukan (ed.). Yume no naka no shizen: Shōwa shoki no shururearisumu kara gendai no kaiga e [Nature in Dreams: From Surrealism in 
the Early Shōwa to Contemporary Painting]. Exhibition catalogue. Gunma: Gunma Kenritsu Tatebayashi Bijutsukan, 2006.

Hamada Mayumi. 'Senzen no Abe Nobuo (Yoshifumi) no katsudō: Takiguchi Shūzō to no kankei o chūshin ni' [Abe Nobuo's (Yoshifumi) Prewar Activities: Focus on the Relationship with Takiguchi Shūzō]. Niigata Kenritsu Kindai Bijutsukan kenkyū kiyō [Bulletin of the Niigata Prefectural Museum of Modern Art] 9 (2010): 9-16.

Hanawa Gingo. 'Mahiru no haru no yume' [Dream of Spring in Broad Daylight]. Kamera kurabu 3, no. 7 (1938): 42-44.

Hanawa Gingo. Seibutsu shashinga no shinhatten' [New Developments in Photographic Images of Still Life]. In Korekushon Nihon shürurearisumu 3: Shürurearisumu no shashin to hihyō [Collection of Surrealism in Japan 3: Surrealist Photography and Criticism], edited by Takeba Jō, 218-222. Tokyo: Hon no Tomosha, 2001.

Hanawa Gingo. 'Shashinga ni okeru chōgenjitsushugi no hatten' [Development of Surrealism in the Photographic Image]. Foto taimusu 15, no. 4 (1938): 30-35.

Hanawa Gingo. 'Shashinga ni okeru zen'eiteki sakufū: Ōsaka no aru shashin kurabu reikai ni te hanasu' [Avant-Garde Style in Photography, Discussion from a Regular Meeting of an Osaka Photo Club]. Foto taimusu 15, no. 5 (1938): 26-29.

Harding, James M. and John Rouse (eds). Not the Other Avant-Garde: The Transnational Foundations of Avant-Garde Performance. Ann Arbor: University of Michigan Press, 2010.

Harris, Steven. Surrealist Art and Thought in the 1930s: Art, Politics, and the Psyche. Cambridge: Cambridge University Press, 2004.

Harootunian, Harry D. 'Constitutive Ambiguities: The Persistence of Modernism and Fascism in Japan's Modern History'. In The Culture of Japanese Fascism, edited by Alan Tansman, 80-111. Durham, NC: Duke University Press, 2009.

Harootunian, Harry D. History's Disquiet: Modernity, Cultural Practice and the Question of Everyday Life. New York: Columbia University Press, 2000.

Harootunian, Harry D. Overcome by Modernity: History, Culture, and Community in Interwar Japan. Princeton, NJ: Princeton University Press, 2002.

Hasegawa Saburō. Kyōdoshi [Chronicle of One's Native Place]. In Korekushon Nihon shūrurearisumu 3: Shūrurearisumu no shashin to hihyō [Collection of Surrealism in Japan 3: Surrealist Photography and Criticism], edited by Takeba Jō, 379-386. Tokyo: Hon no Tomosha, 2001.

Havens, Thomas R. H. Radicals and Realists in the Japanese Nonverbal Arts. Honolulu: University of Hawaii Press, 2006.

Hayami Yutaka. Shururearisumu no kaiga to Nihon: Imēji no juyō to sōzō [Surrealist Painting and Japan: Image Reception and Creation]. Tokyo: Nihon Hōsō Shuppan Kyōkai, 2009.

Hirata, Hosea. The Poetry and Poetics of Nishiwaki Junzaburō: Modernism in Translation. Princeton, NJ: Princeton University Press, 1993.

'Hittorā to kodomo: Hittorā wa shashin no tsuyosa to kowasa o shitteiru' [Hitler and Children: Hitler Knows the Power and Fear of Photography]. Kamera kurabu 10 (1940): 12-14.

Hosoe, Eikoh and Mark Holborn. Eikoh Hosoe: Masters of Photography. New York: Aperture, 1999.

Hutchinson, Rachael. Negotiating Censorship in Modern Japan. London: Routledge, 2013.

Hyōgo Kenritsu Bijutsukan (ed.). Retoro modan Kōbe: Nakayama Iwata tachi ga nokoshita senzen no Kōbe [Nakayama Iwata's Retrospective: A Photographer and Prewar Kobe]. Exhibition catalogue. Kobe: Hyōgo Kenritsu Bijutsukan, 2010. 
lida, Yumiko. Rethinking Identity in Modern Japan: Nationalism as Aesthetics. London: Routledge, 2002.

lizawa Kōtarō. 'Dōjidaijin to shite no Yasui Nakaji' [Nakaji Yasui: A Contemporary]. Translated by Tomoko Kozaki. In Yasui Nakaji, lizawa Kōtarō and Kaneko Ryūichi, Yasui Nakaji shashin sakuhinshū [The Photography of Nakaji Yasui], 6-8. Tokyo: Kokusho Kankōkai, 2005.

lizawa, Kotarō. 'The Evolution of Postwar Photography'. In Anne Wilkes Tucker et al., The History of Japanese Photography, 210-225. New Haven, CT: Yale University Press, 2003.

lizawa Kōtarō. 'Modanizumu to shite no shinkō shashin' [New Photography and Modernism]. In Nihon Modanizumu no kenkyū: Shisō, seikatsu, bunka [Study of Japanese Modernism: Thought, Life, Culture], edited by Minami Hiroshi, 207-229. Tokyo: Burēn Shuppan, 1982.

lizawa Kōtarō. 'Nihon no shashinka tachi to Berurin' [Japanese Photographers and Berlin]. In Tōkyō-Berurin/Berurin-Tōkyō ten [Tokyo-Berlin/Berlin-Tokyo], edited by Mori Bijutsukan, 35-39. Exhibition catalogue. Tokyo: Mori Bijutsukan, 2006.

lizawa Kōtarō. 'Shashinkai e no ekkyōsha, Abe Nobuya to shashin' [Beyond the Borders of the Photography World: Abe Nobuya and Photography]. In Abe Nobuya: Akunaki ekkyōsha [Nobuya Abe 1913-1971: Insatiable Quest beyond Borders], edited by Shioda Jun'ichi et al., 15-16. Exhibition catalogue. Tokyo: Inshōsha, 2018.

lizawa Kōtarō. Shashin ni kaere: 'Kōga' no jidai [Return to Photography: The Age of Kōga]. Tokyo: Heibonsha, 1988.

lizawa Kōtarō. Toshi no shisen: Nihon no shashin 1920-30 nendai [The View of the City: Japanese Photography in the 1920s-1930s]. Osaka: Sōgensha, 1989.

lizawa Kōtarō (ed.). Kōga [Pictures of Light]. Tokyo: Fukkokuban 'Kōga' Kankōkai, 1990.

Ikeda Tatsuo. 'Watashi ni totte shururearisumu to wa nani ka: Sono shiteki na shishiteki na hōkoku' [The Way I See Surrealism, A Private and Personal Historical Report]. Bijutsu techō 336 (1970): 154-161.

Imai Shigeru. 'Kaiga ni arawareta katsuji ni taisuru nōto' [A Note on the Printed Material in Painting]. In Korekushon Nihon shūrurearisumu 2: Shūrurearisumu no bijutsu to hihyō [Collection of Surrealism in Japan 2: Surrealist Art and Criticism], edited by Omuka Toshiharu, 76. Tokyo: Hon no Tomosha, 2001.

Imai Shigeru. 'Kaiga ni okeru montaju ni tsuite' [Montage in Painting]. In Korekushon Nihon shūrurearisumu 2: Shūrurearisumu no bijutsu to hihyō [Collection of Surrealism in Japan 2: Surrealist Art and Criticism], edited by Omuka Toshiharu, 65-66. Tokyo: Hon no Tomosha, 2001.

Imai Shigeru. 'Shururearizumu foto ni tai suru oboegaki' [Surrealist Photography Memorandum]. Foto taimusu 15, no. 10 (1938): 51-55.

Ishii Ayako. '“Zen'ei” ga kagayaita kisetsu' [The Season of Bright 'Avant-Garde']. In Nihon no shashinka 15: Koishi Kiyoshi to zen'ei shashin [Complete Collection of Japanese Photographers 15: Koishi Kiyoshi and Avant-Garde Photography], edited by Nagano Shigeichi, lizawa Kōtarō and Kinoshita Naoyuki, 61-66. Tokyo: Iwanami Shoten, 1999.

Ina Nobuo. '“Kōgakai” ni tsuite' [Kōga Meeting]. Kōga 2, no. 6 (1933): 156-157.

Ina Nobuo. 'Shashinkai e no kōkaijō (II)' [An Open Letter Addressed to the Photography World (II)]. Kōga 2, no.10 (1933): 253. 
Ina Nobuo. 'Shashin ni kaere' [Return to Photography]. In Shashin ni kaere [Return to Photography: Japanese Photography of the 1930s], edited by Zen Foto Gallery. Tokyo: Zen Foto Gallery, 2010.

Ina Nobuo. Shashin, Shōwa gojūnenshi [Photography, History of Fifty Years of Shōwa]. Tokyo: Asahi Shinbunsha, 1978.

Isozaki Arata. 'Han-kaisō: "Ore wa hyōronka janakute hihyōka nan da" to itta Tōno Yoshiaki no koto o omoidashite mita' [Anti-Recollection: Trying to Recall Tono Yoshiaki, Who Said: 'I am Not a Commentator, I am a Critic']. In Kyozō no jidai: Tōno Yoshiaki bijutsu hihyōsen [Art Critics by Yoshiaki Tono], edited by Tōno Yoshiaki, Matsui Shigeru and Imura Yasuko, 307-316. Tokyo: Kawade Shobō Shinsha, 2013.

Itagaki Takao. Kikai to geijutsu to no kōryū [The Correspondence between Machine and Art]. Tokyo: Iwanami Shoten, 1929.

Iwaya Kunio. 'Shururearisumu no kyō: Sono "kakuri" to "inpei" ni tsuite' [Today of Surrealism, and Its 'Isolation' and 'Concealment']. Bijutsu techō 336 (1970): 49-58. Iwaya Kunio. 'Takiguchi Shūzō to Andore Buruton' [Shuzo Takiguchi and André Breton]. Translator unknown. In Omāju Takiguchi Shūzō ten 13: Andore Buruton to Takiguchi Shüzō [André Breton and Shuzo Takiguchi: The 13th Exhibition Homage to Shuzo Takiguchi], ed. Satani Garō, 41-47. Exhibition catalogue. Tokyo: Satani Garō, 1993. Jaguer, Édouard. Les Mystères de la chambre noire: Le Surréalisme et la photographie.

Paris: Flammarion, 1982.

James, Edward. 'La chapeau du people et les chapeaux de la Reine'. Minotaure 9 (1936): 54-59.

Jelinek, Alana. This Is Not Art: Activism and Other 'Non-Art'. London: I.B. Tauris, 2013. 'Joryū sakka ni teigen suru' [Recommendations to Women Artists]. Photo Times 17, no. 4 (1940): 6-11.

Kaigai Chōgenjitsushugi Sakuhinshū: ALBUM SURRÉALISTE [Collection of Foreign Surrealist Works: Surrealist Album]. Mizue 388 (1937).

Kanamaru Shigene. Shinkō shashin no tsukurikata [How to Make New Photography]. Tokyo: Genkōsha, 1932.

Kaneko, Maki. 'New Art Collectives in the Service of the War: The Formation of Art

Organizations during the Asia-Pacific War'. positions: east asia cultures critique 21, no. 2 (2013): 309-350.

Kaneko Maki. 'Seido to shakai' [Institutions and Society]. In Bijutsu no Nihon kingendaishi: Seido, gensetsu, zōkei [Histories of Modern and Contemporary Japan through Art: Institutions, Discourses, Practice], edited by Kitazawa Noriaki, Satō Dōshin and Mori Hitoshi, 451-463. Tokyo: Tōkyō Bijutsu, 2014.

Kantorowicz, Ernst H. The King's Two Bodies: A Study in Mediaeval Political Theology. Princeton, NJ: Princeton University Press, 1957.

Kawahata Naomichi. 'Shashin hekiga no jidai: Pari Banpaku to Nyūyōku Banpaku Kokusaikan Nihonbu chūshin ni' [The Photomural Age: Japanese Exhibits at the Paris International Exposition and the New York World's Fair]. In 'Teikoku' to bijutsu: 1930 nendai Nihon no taigai bijutsu senryaku ['Empire' and Art: Japanese Art of the 1930s and Its Strategic Expansion Abroad], edited by Omuka Toshiharu, 379-578. Tokyo: Kokusho Kankōkai, 2010.

Kern, Anne M. 'Influences and Transformations from Early to Late Surrealist Games'. In The Exquisite Corpse: Chance and Collaboration in Surrealism's Parlor Game, edited by Kanta Kochar-Lindgren, Davis Schneideman and Tom Denlinger, 3-29. Lincoln: University of Nebraska Press, 2009. 
Koga Harue. ‘Chōgenjitsushugi shikan' [Personal Observations about Surrealism]. In Korekushon Nihon shūrurearisumu 15: Shūrurearisumu kihon shiryō shūsei [Collection of Surrealism in Japan 15: Surrealism, Collection of Fundamental Documents], edited by Wada Hirofumi, 81-86. Tokyo: Hon no Tomosha, 2001.

Koga Harue. 'Chōgenjitsushugi shikan' [Une approache du surréalisme]. Translated by Věra Linhartová. In Japon des Avant Gardes, 1910-1970: Exposition, edited by Centre Georges Pompidou, 158-161. Exhibition catalogue. Paris: Éditions du Centre Pompidou, 1986.

Kohara Masashi (ed.). Fuji genkei: Kindai Nihon to Fuji no yama [Visions of Fuji: An Incurable Malady of Modern Japan]. Exhibition catalogue. Nagaizumi-chō, Shizuokaken: Izu Photo Museum, 2011.

Koishi Kiyoshi. 'Kamikōchi kamera kikō' [Record of a Camera Trip to Kamikōchi]. Foto taimusu 15, no. 10 (1938): 44-50.

Koishi Kiyoshi. Satsuei: Sakuga no shingihō [Photography: A New Method for ImageMakng]. Tokyo: Genkōsha, 1936.

Koishi Kiyoshi. 'Seimei no gangu' [Life's Toys]. In Korekushon Nihon shūrurearisumu 3: Shūrurearisumu no shashin to hihyō [Collection of Surrealism in Japan 3: Surrealist Photography and Criticism], edited by Takeba Jō, 61-69. Tokyo: Hon no Tomosha, 2001.

Koishi Kiyoshi. 'Shinkankaku no hyōgen: Riarizumu no kanata e' [Expressions of New Sensibility: Going Beyond Reality]. Kamera āto, June Edition (1935): 148-151.

Koishi Kiyoshi. Shoka shinkei [Early Summer Nerves]. Tokyo: Kokusho Kankōkai, 2005.

Kokatsu Reiko and Yoshimoto Midori (eds). Zen'ei no josei, 1950-1975 [Japanese Women Artists in Avant-Garde Movements, 1950-1975]. Utsunomiya-shi: Tochigi Kenritsu Bijutsukan, 2005.

'Kongo no shashin wa kōde aritai: Hōdō shashin, Geijutsu shashin, Zen'ei shashin nado o chūshin ni purofesshonaru to amachua no zadankai' [The Way for Photography from Now On: Round Table Meeting between Professionals and Amateurs, Focusing on Photojournalist, Art, Avant-Garde and Other Photography]. Foto taimusu 16, no. 3 (1939): 61-69.

Krauss, Rosalind. 'Grids'. October 9 (1979): 50-64.

Krauss, Rosalind. The Originality of the Avant Garde and Other Modernist Myths. Cambridge, MA: MIT Press, 1985.

Krauss, Rosalind. 'Photography in the Service of Surrealism'. In L'Amour fou: Photography and Surrealism, edited by Rosalind Krauss and Jane Livingstone, 15-54. Exhibition catalogue. New York: Abbeville Press, 1986.

Krauss, Rosalind and Jane Livingstone (eds). L'Amour fou: Photography and Surrealism. Exhibition catalogue. New York: Abbeville Press, 1986.

Kuczuńska, Agnieszka. 'Surréalism en 1947 - Occultism and the Post-War Marginalisation of Surrealism'. Art Inquiry. Recherches sur les arts 16 (2014): 87-99.

Kuhn, Christine. 'Film und Foto International Exhibition'. In Tōkyō-Berurin/Berurin-Tōkyō ten [Tokyo-Berlin/Berlin-Tokyo], edited by Mori Bijutsukan, 188-189. Exhibition catalogue. Tokyo: Mori Bijutsukan, 2006.

KuroDalaiJee. 'Performance Collectives in 1960s Japan: With a Focus on the "Ritual School"'. positions: east asia cultures critique 21, no. 2 (2013): 417-447.

Kurosawa Yoshiteru. Nihon no shururearisumu to iu shikōya [Japanese Surrealism, A Field of Thought]. Tokyo: Meibun Shobō, 2016.

Kurosawa Yoshiteru (ed.). Yamanaka Chirū shoshi nenpu [Yamanaka Tiroux Chronologie et Bibliographie]. Tokyo: Tanseisha, 2005. 
Lacan, Dr. 'Le problème du style et les formes paranoïaques de l'expérience'. Minotaure 1 (1933): 68-69.

Laplanche, Jean and Jean-Bertrand Pontalis. The Language of Psychoanalysis. New York: W.W. Norton, 1973.

Lautréamont, Comte de. Maldoror and the Complete Works of Comte de Lautréamont. Translated by Alexis Lykiard. Cambridge: Exact Change, 1994.

'Le surréalisme autour du monde'. Minotaure 10, no. 3 (1937): unpaginated.

'Les Artistes D’Avant-Garde'. Atorie 14, no. 6 (1937): unpaginated.

Leslie, Esther. Hollywood Flatlands: Animation, Critical Theory and the Avant-Garde. London: Verso, 2004.

Levy, Silvano. 'Paul Nougé Constructing Absence'. In Collective Inventions: Surrealism in Belgium, edited by Patricia Allmer and Hilde Van Gelder, 70-83. Leuven: Leuven University Press, 2007.

Linhartová, Vera. Dada et surréalisme au Japon. Paris: Publications Orientalistes de France, 1987.

Lomas, David. The Haunted Self: Surrealism, Psychoanalysis, Subjectivity. New Haven, CT: Yale University Press, 2000.

Low, Morris. Japan on Display: Photography and the Emperor. London: Routledge, 2006.

Lu, David J. Japan: A Documentary History. Armonk: M.E. Sharpe, 1997.

Lucken, Michael. 'Total Unity in the Mirror of Art'. Translated by Francesca Simkin. In Art and War in Japan and Its Empire, edited by Asato Ikeda, Aya L. McDonald and Ming Tiampo, 79-89. Leiden: Brill, 2013.

Lucken, Michael. 'Aphrodite dans le Soleil levant: Images de la Grèce antiques dans le Japon en guerre 1937-1945'. In La Guerre et les Arts, edited by Jean Baechler, 87-99. Paris, Hermann: 2018.

Maddox, Amanda. 'Disobedient Spirit: Kansuke Yamamoto and His Engagement with Surrealism'. In Japan's Modern Divide: The Photographs of Hiroshi Hamaya and Kansuke Yamamoto, edited by Judith Keller and Amanda Maddox, 180-203. Exhibition catalogue. Los Angeles: J. Paul Getty Museum, 2013.

Malt, Johanna. Surrealist Objects of Desire: Surrealism, Fetishism, and Politics. Oxford: Oxford University Press, 2004.

Marcoci, Roxana, et al. The Original Copy: Photography of Sculpture, 1839 to Today. Exhibition catalogue. New York: New York Museum of Modern Art, 2010.

Marotti, William A. Money, Trains and Guillotines: Art and Revolution in 1960s Japan. Durham, NC: Duke University Press, 2013.

Marra, Michael. 'Coincidentia Oppositorium: The Greek Genealogies of Japan'. In Essays on Japan: Between Aesthetics and Literature, 113-129. Leiden: Brill, 2010.

Masuda, Rei. 'Shōwa senzen mae to Onchi Kōshirō, Shiihara Osamu, Ei-Kyū' [Japanese Photography of the 1920s and 1930s: Photographic Works of Koshiro Onchi, Osamu Shiihara and Ei-kyu]. Translated by Kikugo Ogawa. In Modanizumu no kōseki: Onchi Kōshirō, Shiihara Osamu, Ei-Kyū [Traces of Light in Modernism: Koshiro Onchi, Osamu Shiihara and Ei-Kyu], edited by Tokyō Kokuritsu Kindai Bijutsukan, 8-11. Exhibition catalogue. Tokyo: Tokkyō Kokuritsu Kindai Bijutsukan, 1997.

Matsubara Jūzō. 'Torikku shashin no utsushikata' [How to Make Trick Photographs]. Asahi kamera 27, no. 2 (1939): 298-299.

Matsuda Kazuko. Shururearisumu to 'te' [Surrealism and 'Hand']. Tokyo: Suiseisha, 2006. 
Matsumi Teruhiko. Kōkoku shashin no modanizumu: Shashinka Nakayama Iwata to 1930 nendai [Modernity in Commercial Photography: Photography of Nakayama Iwata and the 1930s]. Tokyo: Seikyūsha, 2015.

McAra, Catriona. 'Surrealism's Curiosity: Lewis Carroll and the Femme-Enfant'. Papers of Surrealism 9 (Summer 2011): 1-25.

McClain, James L. Japan, A Modern History. New York: W.W. Norton, 2002.

Michaud, Philippe-Alain. 'La coalescence et la suture'. In La Subversion des images: surréalisme, photographie, film, edited by Quentin Bajac and Clément Chéroux, 173-177. Exhibition catalogue. Paris: Édicion du Centre Pompidou, 2009.

Miller, Scott J. Historical Dictionary of Modern Japanese Literature and Theatre. Lanham, MD: Scarecrow Press, 2009.

Mitsuda Yuri. 'Kukkyoku to kirameki, Nakayama Iwata no sakuhin to jidai' [Flexure and Glitter: Nakayama Iwata's Work and Its Time]. In Nakayama Iwata ten: Modan fotogurafi [Nakayama Iwata: Modern Photography], edited by Ashiya Shiritsu Bijutsu Hakubutsukan, 260-275. Exhibition catalogue. Kyoto: Tankōsha, 2003.

Mitsuda Yuri. 'Yasui Nakaji riarusa no hate - shashin ōgonki no kyojin' YYasui Nakaji, the End of Reality - Giant of Photography's Golden Age]. In Yasui Nakaji et al., Yasui Nakaji shashinshū [Nakaji Yasui Photographer 1903-1942], 8-20. Tokyo: Kyōdo Tsūshinsha, 2004.

Mitsuda Yuri. 'Nihon "gendai bijutsu" no seiritsu to tenkai' [The Establishment and Development of 'Contemporary Art' in Japan]. In Bijutsu no Nihon kingendaishi: Seido, gensetsu, zōkei [Histories of Modern and Contemporary Japan through Art: Institutions, Discourses, Practice], edited by Kitazawa Noriaki, Satō Dōshin and Mori Hitoshi, 527-625. Tokyo: Tōkyō Bijutsu, 2014.

Mitsuda, Yuri. 'The Realism Debate'. In Doryun Chong et al., From Postwar to Postmodern: Art in Japan 1945-1989, Primary Documents, 49. New York: Museum of Modern Art, 2012.

Mitsuda Yuri. 'Shōwa zenki no bijutsukai to shashin sakuhin' [Art World and Photographic Works in the Early Part of Shōwa]. In Shōwaki bijutsu tenrankai no kenkyū: Senzenhen [Research into Art Exhibitions in Shōwa Era, Prewar Edition], edited by Tokyō Bunkazai Kenkyūjo Kikaku Jōhōbu [Tokyo National Research Institute for Cultural Properties], 379-390. Tokyo: Chūō Kōron Bijutsu Shuppan, 2009.

Mitsuda, Yuri. 'Intersections of Art and Photography in 1970s Japan: "Thinking from Dates and Places"'. Translated by Reiko Tomii. In For a New World to Come: Experiments in Japanese Art and Photography, 1968-1979, edited by Yasufumi Nakamori, 28-39. Exhibition catalogue. Houston: Museum of Fine Art Houston, 2015.

Mizuno, Hiromi. Science for the Empire. Stanford, CA: Stanford University Press, 2009. Mizusawa Tsutomu. 'Jikken Kōbō: Mebae to kizashi' [Experimental Workshop: A

Seeding and a Sign]. Translated by Polly Barton. In Jikken Kōbō ten: Sengo geijutsu o kirihiraku [Experimental Workshop: Opening Up Postwar Art], edited by Kanagawa kenritsu kindai bijutsukan, 312-315. Exhibition catalogue. Tokyo: Yomiuri Shinbunsha, 2013.

Moriguchi Tari. Pari shinkō kaiga senshū [Collection of New Art in Paris]. Tokyo: Heibonsha, 1933.

Morita Hajime. 'Obujekō tenbyōfū ni' [A Sketch for Thoughts about Objects]. In Nihon Obuje 1920-1970 nendai danshō [Japanese Object, Fragments of the Decades between 1920-1970], edited by Morita Hajime et al., 22-38. Exhibition catalogue. Tokyo: Bijutsukan Renraku Kyōgikai, 2012. 
Munro, Majella. Communicating Vessels: The Surrealist Movement in Japan, 1923-1970. Cambridge: Enzo Press, 2012.

Muramatsu Masatoshi. 'Genjitsushugi to chōgenjitsushugi' [Reality and Surreality]. In Korekushon Nihon shūrurearisumu 1: Shürurearisumu no shi to hihyō [Collection of Surrealism in Japan 1: Surrealist Poetry and Criticism], edited by Wada Hirofumi, 3-7. Tokyo: Hon no Tomosha, 2000.

Nadeau, Maurice. The History of Surrealism. Translated by Richard Howard with an introduction by Roger Shattuck. New York: Macmillan, 1965.

Nagata Isshū and Takiguchi Shūzō. 'Yume to jinsei oyobi sono tegami' [Dream and Life, Correspondence]. Foto taimusu 15, no. 7 (1938): 82-84.

Nagoya-shi Bijutsukan (ed.). Nihon no shūrurearisumu: 1925-1945 [Surrealism in Japan: 1925-1945]. Exhibition catalogue. Nagoya: Nihon no Shūrurearisumuten Jikkō linkai, 1990.

Nakada Sadanosuke. 'Kokuten no shashin' [Photography at the National Exhibition]. Mizue, no. 415 (1939): 16.

Nakajima Tokuhiro. 'Shashin no "radikarusa"' ['Radicalism' in Photography]. In Yasui Nakaji et al., Yasui Nakaji shashinshū [Nakaji Yasui Photographer 1903-1942], 240-252. Tokyo: Kyōdo Tsūshinsha, 2004.

Nakajima Tokuhiro. 'Toshi no shashinka, Nakayama Iwata - sono shirarezaru ichimen' [Iwata Nakayama, A Photographer of the Modern City - Its Unknown Aspect]. In Shirarezaru Nakayama Iwata [Iwata Nakayama, His Unknown Aspects], edited by Nakajima Tokuhiro and Takasago Miwako, unpaginated. Exhibition catalogue. Tokyo: Seibu Hyakkaten, 1989.

Nakamura Giichi. Nihon kindai bijutsu ronsōshi, Zoku [History of Disputes in Japanese Modern Art, Continued]. Tokyo: Kyūryūdō, 1982.

Nakayama Iwata. 'Fuyu no sakuhinshū' [A Winter Collection of Artworks]. Kamera kurabu 3, no. 1 (1938): unpaginated.

Nakayama Iwata. 'Jun geijutsu shashin' [Pure Art Photography]. Asahi kamera 5, no. 1 (1928): 40-42.

'Naniwa shashinten zadankai' [Symposium on the Occasion of the Naniwa Photography Exhibition]. Foto taimusu 15, no. 9 (1938): 26-33.

Namigata Tsuyoshi. Ekkyō no avangyarudo [Border-Crossing Avant-Garde]. Tokyo: NTT Shuppan, 2005.

Naniwa Shashin Kurabu kaihō [Newsletter of the Naniwa Photography Club] 1-7 (1938).

Nara, Hitoshi. Inexorable Modernity: Japan's Grappling with Modernity in the Arts. Lanham, MD: Lexington Books, 2007.

Nerval, Gérard de. Aurélia and Other Writings. Translated by Robert Duncan and Marc Lowenthal. Boston: Exact Change, 1996.

Nezval, Vítézslav. 'Styrsky.Toyen'. Cahiers d'art 10, no. 5-6 (1936): 135.

Nippon [Japan]. Tokyo: Kokusai Bunka Shinkōkai, 1937.

Nishimura Masahiro (ed.). Korekushon, Toshi modanizumu shishi 14: VOU Kurabu no jikken [Collection: Poetry and Illustration of Urban Modernity, Volume 14: Experiments of VOU Club]. Tokyo: Yumani Shobō, 2011.

Nishimura Tomohiro. Nihon geijutsu shashinshi: Ukiyo-e kara dejikame made [History of Art Photography in Japan: From Ukiyo-e to Digital Camera]. Kokubunji: Bigaku Shuppan, 2008.

Oguma, Eiji. A Genealogy of 'Japanese' Self-Images. Translated by David Askew. Melbourne: Trans Pacific, 2002.

Okamoto Tarō. 'Pari no nakama tachi' [Paris Friends]. In Okamoto Tarō chosakushū, 2: Kuroi Taiyō [Okamoto Tarō Collection, 2: Dark Sun], 96-134. Tokyo: Kōdansha, 1980. 
Omuka Toshiharu. Hijōji no modanizumu: 1930 nenndai teikoku Nihon no bijutsu [Modernism in a Time of Crisis: Art in 1930s Imperial Japan]. Tokyo: Tōkyō Daigaku Shuppankai, 2017.

Omuka Toshiharu. Taishōki shinkō bijutusu undō no kenkyū [The Japanese Modern Art Movement and the Avant-Garde, 1920-1927]. Tokyo: Sukaidoa, 1995.

Omuka Toshiharu (ed.). Korekushon Nihon shūrurearisumu 2: Shūrurearisumu no bijutsu to hihyō [Collection of Surrealism in Japan 2: Surrealist Art and Criticism]. Tokyo: Hon no Tomosha, 2001.

Orban, Clara Elizabeth. The Culture of Fragments: Words and Images in Futurism and Surrealism. Amsterdam: Atlanta: Rodopi, 1997.

O'Sullivan, Simon. 'From Stuttering and Stammering to the Diagram: Towards a Minor Art Practice?'. In Minor Photography: Connecting Deleuze and Guattari to Photography Theory, edited by Mieke Bleyen, 3-16. Leuven: Leuven University Press, 2012.

Otani, Shogo. 'Dreams of the Horizon - Introduction'. Translated by Ogawa Kikuko. In Chiheisen no yume: Shōwa 10 nendai no gensō kaiga [Dreams of the Horizon: Fantastic Paintings in Japan 1935-1945], edited by Tokyō Kokuritsu Kindai Bijutsukan, Ōtani Shōgo, 20-29. Exhibition catalogue. Tokyo: Tōkyō Kokuritsu Kindai Bijutsukan, 2003.

Ōtani Shōgo. 'Fukuzawa Ichrō to korāju: 1930 nendai shoki ni okeru shūrurearisumu juyō o megutte' [Ichiro Fukuzawa and Collage: A Japanese Artist's Adoption of Surrealism in the Early 1930s]. Tõkyō Kokuritsu Kindai Bijutsukan Kenkyū Kiyō [Bulletin of the National Museum of Modern Art] 5 (1996): 55-76.

Ōtani Shōgo. Gekidōki no avangyarudo: Shururearisumu to Nihon no kaiga 1928-1953 [Avant-Garde in Turbulent Times: Surrealism and Japanese Painting, 1928-1953]. Tokyo: Kokusho Kankōkai, 2016.

Ōtani Shōgo and Yamada Satoshi. '1930 nendai Dari būmu no shinsō, Taidan: Yamada Satoshi x Ōtani Shōgo' TThe Truth about the Dalí Boom in the 1930s, Cross Talk: Yamada Satoshi x Ōtani Shōgo]. Bijutsu techō 68, no. 1043 (October 2016): 80-85.

Ōtsuji Kenji. 'Furoido to kindai kaiga' [Freud and Modern Painting]. In Korekushon Nihon shūrurearisumu 2: Shūrurearisumu no bijutsu to hihyō [Collection of Surrealism in Japan 2: Surrealist Art and Criticism], edited by Omuka Toshiharu, 131-133. Tokyo: Hon no Tomosha, 2001.

Ōtsuji Kiyoji. Shashin nōto [Note of Photography]. Tokyo: Bijutsu Shuppansha, 1989.

Ōtsuji Kiyoji, et al. Ōtsuji Kiyoji no shashin: Deai to koraborēshon [Ōtsuji Kiyoji's Photography: Encounters and Collaborations]. Tokyo: Firumu Āto sha, 2007.

Pari Tōkyō Shinkō Bijutsu tenrankai mokuroku [Catalogue of the Exhibition of New Art in Paris and Tokyo]. In Korekushon Nihon shūrurearisumu 15: Shūrurearisumu kihon shiryō shūsei [Collection of Surrealism in Japan 15: Surrealism, Collection of Fundamental Documents], edited by Wada Hirofumi, 151-174. Tokyo: Hon no Tomosha, 2001.

Parker, lan. Japan in Analysis: Cultures of the Unconscious. New York: Palgrave Macmillan, 2008.

Parr, Martin and Gerry Badger. The Photobook. Volume 1. London: Phaidon Press, 2007.

Plant, Margaret. 'Shopping for the Marvellous: The Life of the City in Surrealism'. In Surrealism: Revolution by Night, edited by Michael Lloyd, Ted Gott and Christopher Chapman, 83-105. Exhibition catalogue. Canberra: National Gallery of Australia, 1993. 
Poivert, Michel. 'Les images du dehors'. In La Subversion des images: surréalisme, photographie, film, edited by Quentin Bajac and Clément Chéroux, 65-70. Exhibition catalogue. Paris: Éditions du Centre Pompidou, 2009.

Polizzotti, Mark. Revolution of the Mind: The Life of André Breton. Boston: Black Widow Press, 2009.

Powell, Kirsten H. 'Hands-On Surrealism'. Art History 20, no. 4 (1997): 516-533.

Rexer, Lyle. The Edge of Vision: The Rise of Abstraction in Photography. New York: Aperture, 2009.

Richie, Donald. 'Foreword'. In Yasunari Kawabata, The Scarlet Gang of Asakusa, ix-xxxii. Berkeley: University of California Press, 2005.

Rosenblaum, Naomi. A World History of Photography. New York: Abbeville Press, 1997.

Ross, Kerry. Photography for Everyone, The Cultural Lives of Cameras and Consumers in Early Twentieth-Century Japan. Stanford, CA: Stanford University Press, 2015.

Rothman, Roger. Tiny Surrealism: Salvador Dali and the Aesthetics of the Small. Lincoln: University of Nebraska Press, 2012.

Rubin, Jay. Injurious to Public Morals: Writers and the Meiji State. Seattle: University of Washington Press, 1984.

Ruoff, Kenneth. 'Japanese Tourism to Mukden, Nanjing, and Qufu, 1938-1943'. Japan Review 27 (2014): 171-200.

Sakata Minoru. 'Anchishurubariarizumu to Anchiavangarito (Hizen'ei geijutsuka, Giji chōgenjitsushugi haisekiron)' [Anti-Surrvariarism and Anti-Avantgardian: A Non-AvantGarde Artist's Boycott of Pseudo-Surrealism]. Kamera āto 3 (1939): 20-22.

Sakata Minoru. 'Atarashiki waraji' [A New Pair of Straw Sandals]. Kamera āto 7 (1940): 63-67, 72.

Sakata Minoru. '"Chōgenjitsushugi shashin" [fotoshūrearisumu] to "Chūshōzōei" [fotoabusutorakushon] no gutaiteki na kaisetsu 1, 2' [A Basic Explanation of 'PhotoSurrealism' and 'Photo-Abstraction' 1, 2]. In Korekushon Nihon shūrurearisumu 3: Shürurearisumu no shashin to hihyō [Collection of Surrealism in Japan 3: Surrealist Photography and Criticism], edited by Takeba Jō, 350-360. Tokyo: Hon no Tomosha, 2001.

Sakata Minoru. 'Foto abusutorakushon to Foto shururearizumu' (1-3) [Photo Abstraction and Photo Surrealism (1-3)]. In Korekushon Nihon shūrurearisumu 3: Shūrurearisumu no shashin to hihyō [Collection of Surrealism in Japan 3: Surrealist Photography and Criticism], edited by Takeba Jō, 112-136. Tokyo: Hon no Tomosha, 2001.

Sakata Minoru. 'Foto abusutorakushon to Foto shururearizumu' (4) [Photo Abstraction and Photo Surrealism (4)]. Shashin geppō, March Edition (1938): 45-51.

Sakata Minoru. 'Zen'ei shashin sakuhin no gijutsuteki na kaisetsu' [The Technological Explanation of Avant-Garde Photography]. Photo Times 15, no. 12 (1938): 58-64.

Sakata Minoru. 'Sakuga gihō tanaoroshi chō' (1) [Inventory Notebook of a Picture Making Process]. Foto taimusu 16, no. 4 (1939): 71-76.

Sakata Minoru. 'Sakuga gihō tanaoroshi chō' (2) [Inventory Notebook of a Picture Making Process]. Foto taimusu 16, no. 5 (1939): 55-60.

Sakata Minoru. 'Sakuga gihō tanaoroshi chō' (3) [Inventory Notebook of a Picture Making Process]. Foto taimusu 16, no. 7 (1939): 41-44.

Sakata Minoru. Shashin no zōkei bunka e no hōshi, Zōkei shashin no seikaku [Photography in the Service of Plastic Culture, Characteristics of Plastic Photography]. Tokyo: Arusu, 1941.

Sakata Minoru. Zōkei shashin 1934-1941: Sakata Minoru sakuhinshū [Structure in Photography: Minoru Sakata's Anthology]. Nagoya: Arumu, 1988. 
Sas, Miryam. Fault Lines: Cultural Memory and Surrealism. Stanford, CA: Stanford University Press, 1999.

Sawa Masahiro (ed.). Korekushon, Toshi modanizumu shishi 15: VOU Kurabu to jūgonen sensōina noi [Collection: Poetry and Illustration of Urban Modernity, Volume 15: VOU Club and Fifteen Year War]. Tokyo: Yumani Shobō, 2011.

Sawa Masahiro and Wada Hirofumi (eds). Nihon no Shürurearisumu [Japanese Surrealism]. Tokyo: Sekai Shisōsha, 1995.

'Sekaiichi no dokushinsha - Adorufu Hittorā' [Number One Bachelor of the World: Adolf Hitler]. Foto taimusu 15, no. 4 (1938): 22.

'Shashin Zōkei Kenkyūkai ni tsuite: Photo Experiment Group' [Photo Plasticity Research Association: Photo Experiment Group]. Foto taimusu 16, no. 4 (1939): 28.

'Schönheit im Olympischen Kampf, Sekai no wakamono no shukusai! Doitsu ga tsukutta orimupikku jojishi' [Schönheit im Olympischen Kampf, Festival of World's Youth! Epic Poetry of the Olympic Games Organised by Germany]. Foto taimusu 15, no. 5 (1938): 20-25.

Shibata Ryūji. 'Nachisu no kamera seisaku' [Nazi Camera Policies]. Kamera kurabu, October Edition (1940): 15.

Shigemi, Inaga. 'The Impossible Avant-Garde in Japan, Does the Avant-Garde Exist in the Third World? Japan's Example: A Borderline Case of Misunderstanding in Aesthetic Intercultural Exchange'. Translated by Margaret J. Flynn. Yearbook of Comparative and General Literature 41 (1993): 67-75.

Shimozato Yoshio. 'Chōgenjitsu kaiga no hōhō' [Methods in Surrealist Painting]. In Korekushon Nihon shürurearisumu 14: Ei Kyū, Shimozato Yoshio, renzu no avangyarudo [Collection of Surrealism in Japan 14: Ei Kyū, Shimozato Yoshio, AvantGarde of the Lens], edited by Yamada Satoshi, 264-265. Tokyo: Hon no Tomosha, 2001.

Shimozato Yoshio. 'Chōgenjitsu kaiga to sutairu' [Surrealist Painting and Style]. In Korekushon Nihon shūrurearisumu 14: Ei-Kyū, Shimozato Yoshio, renzu no avangyarudo [Collection of Surrealism in Japan 14: Ei-Kyū, Shimozato Yoshio, AvantGarde of the Lens], edited by Yamada Satoshi, 261-263. Tokyo: Hon no Tomosha, 2001.

Shimozato Yoshio. 'Chūshōha no tenkai: Shūrureyarisumu to no kōryū ni tsuite' [Development of Abstraction, Exchange with Surrealism]. In Korekushon Nihon shürurearisumu 14: Ei-Kyū, Shimozato Yoshio, renzu no avangyarudo [Collection of Surrealism in Japan 14: Ei-Kyū, Shimozato Yoshio, Avant-Garde of the Lens], edited by Yamada Satoshi, 256-258. Tokyo: Hon no Tomosha, 2001.

Shimozato Yoshio. 'Foto amachua kō' [Thoughts of a Photo Amateur]. In Korekushon Nihon shūrurearisumu 14: Ei-Kyū, Shimozato Yoshio, renzu no avangyarudo [Collection of Surrealism in Japan 14: Ei-Kyū, Shimozato Yoshio, Avant-Garde of the Lens], edited by Yamada Satoshi, 284-285. Tokyo: Hon no Tomosha, 2001.

Shimozato Yoshio. 'Gaizai suru hishatai ni yorite hi-shōkeiteki zōei (1)' [Non- Figurative Imaging of External Objects (1)]. Foto taimusu 16, no.12 (1939): 46-50.

Shimozato Yoshio. 'Gaizai suru hishatai ni yorite hi-shōkeiteki zōei (2)' [Non-Figurative Imaging of External Objects (2)]. Foto taimusu 17, no. 1 (1940): 47-50.

Shimozato Yoshio. ' "L'art non-figuratif” kaisetsu' [Explanation of 'Non-Figurative Art']. In Korekushon Nihon shürurearisumu 14: Ei-Kyū, Shimozato Yoshio, renzu no avangyarudo [Collection of Surrealism in Japan 14: Ei-Kyū, Shimozato Yoshio, AvantGarde of the Lens], edited by Yamada Satoshi, 254-255. Tokyo: Hon no Tomosha, 2001. 
Shimozato Yoshio. Mesemu zoku: Chōgenjitsushugi shashin shū [Mesemb Genus, Collection of Surrealist Photographs]. Nagoya: Self-published, 1940.

Shimozato Yoshio. 'Niko no tēma ni yorite' [Two Themes]. In Korekushon Nihon shūrurearisumu 14: Ei-Kyū, Shimozato Yoshio, renzu no avangyarudo [Collection of Surrealism in Japan 14: Ei-Kyū, Shimozato Yoshio, Avant-Garde of the Lens], edited by Yamada Satoshi, 259-260. Tokyo: Hon no Tomosha, 2001.

Silverberg, Miriam. Erotic Grotesque Nonsense: The Mass Culture of Japanese Modern Times. Berkeley: University of California Press, 2006.

Smith, Henry. 'Tokyo as an Idea: An Exploration of Japanese Urban Thought Until 1945'. Journal of Japanese Studies 4, no. 1 (1978): 45-80.

Solt, John. 'Perception, Misperception, Nonperception'. In Yamamoto Kansuke et al., Yamamoto Kansuke: Conveyor of the Impossible, 19-67. Exhibition catalogue. Tokyo: Tokyō Sutēshion Gyararī, 2001.

Sontag, Susan. On Photography. New York: Farrar, Strauss and Giroux, 1977.

Schwartz, Arturo. Man Ray, The Rigour of Imagination. London: Thames and Hudson, 1977.

Sretenović, Dejan. Urnebesni Kliker: Umetnost i Politika Beogradskog Nadrealizma [The Frenzied Marble: Art and Politics of Belgrade Surrealism]. Belgrade: Službeni glasnik, 2016.

Stojković, Jelena. 'Language of Light: Legacy of Surrealism in 1930s Japanese Photography'. MA dissertation, School of Oriental and African Studies, University of London, 2009.

Stojković, Jelena. 'Sakata Minoru's "No-Things": Photographic Plasticity in Japan (1939-1940)'. In Object Fantasies, Experience and Creation, edited by Philippe Cordez, Romana Kaske, Julia Sviello and Susanne Thürigen, 155-173. Berlin: Walter de Gruyter, 2018.

Stojković, Jelena. 'Systematic Confusion and the Total Discredit of the World of Reality: Surrealism and Photography in Japan of the 1930s'. In Minor Photography: Connecting Deleuze and Guattari to Photography Theory, edited by Mieke Bleyen, 163-183. Leuven: Leuven University Press, 2012.

Stone-Richards, Michael. 'Failure and Community: Preliminary Questions on the Political in the Culture of Surrealism'. In Surrealism, Politics and Culture, edited by Raymond Spiteri and Donald LaCoss, 300-336. Burlington, VT: Ashgate, 2003.

Sugita Hideo. 'Fotoguramu no jiyū na seisaku no tame ni' [For a Free Production of Photograms]. In Korekushon Nihon shürurearisumu 14: Ei-Kyū, Shimozato Yoshio, renzu no avangyarudo [Collection of Surrealism in Japan 14: Ei-Kyū, Shimozato Yoshio, Avant-Garde of the Lens], edited by Yamada Satoshi, 41-44. Tokyo: Hon no Tomosha, 2001.

'Tairiku genchi hōkoku zadankai' [Report from the Continent Symposium]. Foto taimusu 17, no. 3 (1940): 71-81.

'Tairiku to shashin no zadankai' [A Round Table Discussion of the Continent and Photography]. Foto taimusu 16, no. 6 (1939): 85-92.

Takahashi Wataru. 'Tsū kansho' [Two Impressions]. Kameraman, June Edition (1938): 24-26.

Takashina, Shūji. 'Introduction'. In Japon des avant gardes, 1910-1970: Exposition, edited by Centre Georges Pompidou, 23-28. Exhibition catalogue. Paris: Éditions du Centre Pompidou, 1986.

Takeba, Joe. 'The Age of Modernism: From Visualization to Socialization'. In Anne Wilkes Tucker et al., The History of Japanese Photography, 144-157. New Haven, CT: Yale University Press, 2003. 
Takeba Jō. 'Aru chāto e no chūshaku: Nagoya no shashinshi o meguru danshō' [Annotations on a Certain Chart: Pieces of Photography History in Nagoya]. Rear 14 (2006): 2-14.

Takeba Jō. Ikyō no modanizumu: Manshū shashin zenshi [The Development of Japanese Modern Photography in Manchoukuo]. Exhibition catalogue. Tokyo: Kokusho Kankōkai, 2017.

Takeba Jō (ed.). Korekushon Nihon shūrurearisumu 3: Shūrurearisumu no shashin to hihyō [Collection of Surrealism in Japan 3: Surrealist Photography and Criticism]. Tokyo: Hon no Tomosha, 2001.

Takiguchi Shūzō. 'Au Japon'. Cahiers d’art 7-10 (1935): 132.

Takiguchi Shūzō. 'Amerika ni watatta Dari' [Dalí Goes to America]. In Takiguchi Shūzō, Ōoka Makoto et al., Korekushon Takiguchi Shūzō 13, Senzen, senchūhen III: 1939-1944 [Collection Takiguchi Shūzō 13, Prewar and War Period 3, 1939-1944], 138-141. Tokyo: Misuzu Shobō, 1995.

Takiguchi Shūzō. 'Buttai to shashin tokuni shururearisumu no obuje ni tsuite' [Object and Photography, Especially the Surrealist Object]. Foto taimusu 15, no. 8 (1938): 64-68.

Takiguchi Shūzō. 'Chōgenjitsushugi no shōzō shashin: Rondon de dairyūkō' [Surrealist Portrait Photography, A Major Trend in London]. Foto taimusu 15, no. 9 (1938): 35-37.

Takiguchi Shūzō. 'Dari no kinkyō’ [Dali's Recent Activities]. In Takiguchi Shūzō, Ōoka Makoto et al., Korekushon Takiguchi Shūzō 13, Senzen, senchūhen III: 1939-1944 [Collection Takiguchi Shūzō 13, Prewar and War Period 3, 1939-1944], 133-137. Tokyo: Misuzu Shobō, 1995.

Takiguchi Shūzō. 'Dōra Māru' [Dora Maar]. Photo Times 17, no. 4 (1940): 22-23.

Takiguchi Shūzō. 'Foto Montaaju (Baabara Moogan)' [Photomontage (Barbara Morgan)]. In Takiguchi Shūzō, Ōoka Makoto et al., Korekushon Takiguchi Shūzō 13, Senzen senchū hen III: 1939-1944 [Collection Takiguchi Shūzō 13, Prewar and War Period 3, 1939-1944], 309-346. Tokyo: Misuzu Shobō, 1995.

Takiguchi Shūzō. 'Furoitoshugi to gendai geijutsu' [Freudianism and Contemporary Art]. In Takiguchi Shūzō, Ōoka Makoto et al., Korekushon Takiguchi Shūzō 13, Senzen senchū hen III: 1939-1944 [Collection Takiguchi Shūzō 13, Prewar and War Period 3, 1939-1944], 245-254. Tokyo: Misuzu Shobō, 1995.

Takiguchi Shūzō. Futatsu no pōtorēto' [Two Portraits]. In Takiguchi Shūzō, Ōoka Makoto et al., Korekushon Takiguchi Shūzō 13, Senzen, senchūhen III: 1939-1944 [Collection Takiguchi Shūzō 13, Prewar and War Period 3, 1939-1944], 142-145. Tokyo: Misuzu Shobō, 1995.

Takiguchi Shūzō. 'Jikkenteki shashinka to shite no Mohori Nagii' [Moholy-Nagy, An Experimental Photographer]. Foto taimusu 15, no. 9 (1938): 41-48.

Takiguchi Shūzō. 'Kazari mado no aru tenrankai' [An Exhibition with a Show Window Potential]. In Nihon no shürurearisumu: 1925-1945 [Surrealism in Japan: 19251945], edited by Nagoya-shi Bijutsukan, 148-149. Exhibition catalogue. Nagoya: Nihon no Shūrurearisumuten Jikkō linkai, 1990.

Takiguchi Shūzō. 'Kindai zōkei geijutsu (Jiideion Uerukaa)' [Modern Plastic Art (Carola Giedion- Welcker)]. In Takiguchi Shūzō, Ōoka Makoto et al., Korekushon Takiguchi Shūzō 12, Senzen senchū hen II: 1937-1938 [Collection Takiguchi Shūzō 12, Prewar and War Period 2, 1937-1939], 207-216. Tokyo: Misuzu Shobō, 1993.

Takiguchi Shūzō. 'Man Rei' [Man Ray]. In Korekushon Nihon shūrurearisumu 3: Shūrurearisumu no shashin to hihyō [Collection of Surrealism in Japan 3: Surrealist Photography and Criticism], edited by Takeba Jō, 3-10. Tokyo: Hon no Tomosha, 2000. 
Takiguchi Shūzō. 'Minotaure'. In Takiguchi Shūzō, Ōoka Makoto et al., Korekushon Takiguchi Shūzō 11, Senzen senchū hen I: 1926-1936 [Collection Takiguchi Shūzō 11, Prewar and War Period 1, 1926-1936], 376-377. Tokyo: Misuzu Shobō, 1991.

Takiguchi Shūzō. 'Mohori Nagii kara no tegami sono ta' [A Letter from Moholy-Nagy and Other]. Foto taimusu 17, no. 1 (1940): 22-23.

Takiguchi Shūzō. 'Nazo no sōzōsha: Sarubadōru Dari' [Salvador Dali, Creator of Riddles]. In Takiguchi Shūzõ, Ōoka Makoto et al., Korekushon Takiguchi Shūzō 13, Senzen senchū hen III: 1939-1944 [Collection Takiguchi Shūzō 13, Prewar and War Period 3, 1939-1944], 3-25. Tokyo: Misuzu Shobō, 1995.

Takiguchi Shūzō. 'Rune Maguritto' [René Magritte]. Mizue 414 (1939): 4-8.

Takiguchi Shūzō. 'Saruvadoru Dari no keitaigaku' [Salvador Dalís Morphology]. Mizue 400 (1938): 13-16.

Takiguchi Shūzō. 'Shashin to chōgenjitsushugi' [Photography and Surrealism]. Foto taimusu, 15, no. 2 (1938): 50-55.

Takiguchi Shūzō. 'Shashin to kaiga no kōryū' [Interchange between Photography and Painting]. Foto taimusu 15, no. 5 (1938): 30-37.

Takiguchi Shūzō. 'Shashin to zōkeisei no saikentō' [Re-Examining Photography and Plasticity]. Foto taimusu 17, no. 11 (1940): 23-25.

Takiguchi Shūzō. 'Shimozato Yoshio hencho "Mesemu zoku" ni tsuite' [Mesemb Genus, Authored and Edited by Shimozato Yoshio]. In Korekushon Nihon shūrurearisumu 14: Ei-Kyū, Shimozato Yoshio, renzu no avangyarudo [Collection of Surrealism in Japan 14: Ei- Kyū, Shimozato Yoshio, Avant-Garde of the Lens], edited by Yamada Satoshi, 253. Tokyo: Hon no Tomosha, 2001.

Takiguchi Shūzō. 'Shururearisumu no jikken ni arawareta taishō' (Saruvadooru Dari) [The Object as Revealed in Surrealist Experiment (Salvador Dali)]. In Takiguchi Shūzō, Ōoka Makoto et al., Korekushon Takiguchi Shūzō 11, Senzen senchū hen I: 1926-1936 [Collection Takiguchi Shūzō 11, Prewar and War Period 1, 1926-1936], 415-425. Tokyo: Misuzu Shobō, 1991.

Takiguchi Shūzō. 'Shokubutsu no kiroku' [Recording Plants]. Foto taimusu 16, no. 1 (1939): 57-61.

Takiguchi Shūzō. 'Ujeinu Atoje' [Eugène Atget]. In Takiguchi Shūzō, Makoto Ōoka et al., Korekushon Takiguchi Shüzō 11, Senzen senchū hen I: 1926-1936 [Collection Takiguchi Shūzō 11, Prewar and War Period 1, 1926-1936], 347-350. Tokyo: Misuzu Shobō, 1991.

Takiguchi Shūzō. 'Zōkei kunren to shashin' [The Practice of Plasticity and Photography]. In Takiguchi Shūzō, Ōoka Makoto et al., Korekushon Takiguchi Shūzō 13, Senzen senchū hen III: 1939-1944 [Collection Takiguchi Shūzō 13, Prewar and War Period 3, 1939-1944], 175-193. Tokyo: Misuzu Shobō, 1995.

Takiguchi Shūzō. 'Zōkei shashin kōenkai no kiroku yori' [Report on a Lecture about Plastic Photography]. Foto taimusu 16, no. 5 (1939): 93-96.

Takiguchi Shūzō (trans.). 'Chōgenjitsushugi to kaiga (Andore Buruton)' [Surrealism and Painting (André Breton)]. In Takiguchi Shūzō, Ōoka Makoto et al., Korekushon Takiguchi Shūzō 11, Senzen senchū hen 1: 1926-1936 [Collection Takiguchi Shūzō 11, Prewar and War Period 1, 1926-1936], 181-218. Tokyo: Misuzu Shobō, 1991.

Takiguchi Shūzō. Kindai geijutsu [Modern Art]. Tokyo: Bijutsu Shuppansha, 1962. Takizawa Kyōji. 'Avangyarudo kara puroretaria bijutsu e: Bijutsu seido no yōdō to kaihen' [From Avant-Garde to Proletarian Art: The Shaking and Reorganisation of Art Institutions]. In Bijutsu no Nihon kingendaishi: Seido, gensetsu, zōkei [Histories of Modern and Contemporary Japan through Art: Institutions, Discourses, Practice], 
edited by Kitazawa Noriaki, Satō Dōshin and Mori Hitoshi, 237-247. Tokyo: Tōkyō Bijutsu, 2014.

Taniguchi Eri. 'Kikaiteki shikaku media no "eikyō" kara miru Shōwa 10 nendai no zen'ei kaiga - Takiguchi Shūzō "Eikyō ni tsuite" (Shōwa 14 nen) o tegakari ni' [Avant-Garde Painting of the 1930s Seen from the Perspective of Mechanical Media 'Influence', in Reference to Takiguchi Shūzō's 'On influence' (1939)]. In Shōwaki bijutsu tenrankai no kenkyū: Senzenhen [Research into Art exhibitions in Shōwa Era, Prewar Period], edited by Tōkyō Bunkazai Kenkyūjo Kikaku Jōhōbu [Tokyo National Research Institute for Cultural Properties], 391-409. Tokyo: Kokuritsu Bunkazai Kikō Tōkyō Bunkazai Kenkyūjo, 2009.

Taniguchi Eri. 'Kindai Nihonno 'zen'ei geijutsu' to media, tekunoroji' ['Avant-Garde Art', Media, and Technology in Modern Japan]. PhD dissertation, Tokyo University of the Arts, 2011.

Tanpei Shashin Kurabu, lizawa Kōtaro and Kaneko Ryūichi. Hikari [Light]. Tokyo: Kokusho Kankōkai, 2006.

Tansman, Alan (ed.). The Culture of Japanese Fascism. Durham, NC: Duke University Press, 2009.

Taylor, Brandon. Collage: The Making of Modern Art. London: Thames and Hudson, 2004.

Tezuka, Miwako. 'Experimentation and Tradition: The Avant-Garde Play Peirrot Lunaire by Jikken Kōbō and Takechi Tetsuji' . Art Journal 70, no. 3 (2011): 64-85.

Tezuka, Miwako. 'Jikken Kōbō and Takiguchi Shūzō: The New Deal Collectivism of 1950s Japan’. positions: east asia cultures critique 21, no. 2 (2013): 351-381.

Tezuka, Miwako. 'Jikken Kōbō (Experimental Workshop): Avant-Garde Experiments in Japanese Art of the 1950s' PhD dissertation, Columbia University, New York, 2005.

Tiampo, Ming. Gutai: Decentering Modernism. Chicago: University of Chicago Press, 2011. Tōkyō Kokuritsu Kindai Bijutsukan (ed.). Shururearisumu ten [Exhibition of Surrealism]. Exhibition catalogue. Tokyo: Tōkyō Kokuritsu Kindai Bijutsukan, 1975.

Tōkyō-to Shashin Bijutsukan (ed.). Nihon kindai shashin no seiritsu to tenkai [The Founding and Development of Modern Photography in Japan]. Exhibition catalogue. Tokyo: Tōkyō-to Shashin Bijutsukan, 1995.

Tōkyō-to Shashin Bijutsukan. Kōga to shinkō shashin: Modanizumu no Nihon [The Magazine and the New Photography: KOGA and Japanese Modernism]. Exhibition catalogue. Tokyo: Kokusho Kankōkai, 2018.

Tomii, Reiko. 'Introduction: Collectivism in Twentieth-Century Japanese Art with a Focus on Operational Aspects of Dantai'. positions: east asia cultures critique 21, no. 2 (2013): 225-267.

Tomii, Reiko. Radicalism in the Wilderness, International Contemporaneity and 1960s Art in Japan. Cambridge: MIT Press, 2016.

Tsuchiya Seiichi. 'Midasareta "kiroku" no arika: "Shashin hyaku nen" saikō' [The Whereabouts of the 'Record' Discovered: Reflections on a Century of Photography]. Translator unknown. In Nihon shashin no 1968: 1966-1974 Futtō suru shashin no mure [1968, Japanese Photography: Photographs That Stirred Up Debate, 19661974], edited by Tokyō-to Shashin Bijutsukan, XIII-XXII. Exhibition catalogue. Tokyo: Tōkyō-to Shashin Bijutsukan, 2013.

Tsukahara Fumi. Setsudan suru bigaku: Avangyarudo geijutsu shisōshi [Cutting Edge Avant-Garde - History of Thought of Avant-Garde Art]. Tokyo: Ronsōsha, 2013.

Tsuruoka Yoshihisa (ed.). Korekushon, Toshi modanizumu shishi 3, Shūrurearisumu [Collection: Poetry and Illustration of Urban Modernity, Volume 3: Surrealism]. Tokyo: Yumani Shobō, 2009. 
Tucker, Anne Wilkes, et al. The History of Japanese Photography. Exhibition catalogue. New Haven, CT: Yale University Press, 2003.

T.Y. 'Geijutsu to yūmoa ni kansuru nōto' [Notes concerning Art and Humour]. Mizue 401, no. 7 (1938): 7-10.

Virmaux, Alain and Odette Virmaux. La Constellation surréaliste. Lyon: La Manufacture, 1988.

Volk, Alicia. 'Authority, Autonomy, and the Early Taishō "Avant-Garde"'. positions: east asia cultures critique 21, no. 2 (2013): 451-473.

Volk, Alicia. 'Katsura Yuki and the Japanese Avant-Garde'. Woman's Art Journal 24, no. 2 (2004): 3-9.

Wada Hirofumi (ed.). Korekushon Nihon shūrurearisumu 15: Shūrurearisumu kihon shiryō shūsei [Collection of Surrealism in Japan 15: Surrealism, Collection of Fundamental Documents]. Tokyo: Hon no Tomosha, 2001.

Wada Hirofumi (ed.). Korekushon Nihon shürurearisumu [Collection of Surrealism in Japan]. Tokyo: Hon no Tomosha, 1999-2001.

Wada-Marciano, Mitsuyo. Nippon Modern: Japanese Cinema of the 1920s and 1930s. Honolulu: University of Hawai'i Press, 2008.

Walker, lan. City Gorged with Dreams: Surrealism and Documentary Photography in Interwar Paris. Manchester: Manchester University Press, 2002.

Walker, lan. So Exotic, So Homemade: Surrealism, Englishness and Documentary Photography. Manchester: Manchester University Press, 2007.

Warehime, Marja. Brassaï: Images of Culture and Surrealist Observer. Baton Rouge: Louisiana State University Press, 1996.

Weisenfeld, Gennifer. MAVO: Japanese Artists and the Avant-Garde 1905-1931. Berkeley: University of California Press, 2010.

Weisenfeld, Gennifer. 'Touring Japan-as-Museum: NIPPON and Other Japanese Imperial Travelogues'. positions: east asia culture critique 8, no. 3 (2000): 747-793.

Wilson, Sandra. The Manchurian Crisis and Japanese Society, 1931-33. London: Routledge, 2002.

Wilson, Sandra. 'Rethinking Nation and Nationalism in Japan'. In Nation and Nationalism in Japan, edited by Sandra Wilson, 1-20. London: Routledge, 2002.

Wood, Ghislaine. Surreal Things: Surrealism and Design. London: V\&A Publications, 2007.

Wu, Chinghsin. 'Transcending the Boundaries of the "isms": Pursuing Modernity through the Machine in 1920s and 1930s Japanese Avant-Garde Art'. In Rethinking Japanese Modernism, edited by Roy Starrs, 339-361. Leiden: Brill, 2012.

Yabumae Tomoko. 'Chūshō kaiga no chinmoku: Hasegawa Saburō ni okeru "koten" to "zen'ei"' The Silence of Abstract Painting: 'Classics' and 'Avant-Garde' in Hasegawa Saburō's Work]. In Kurashikku modan: 1930 nendai Nihon no geijutsu [Classically Modern: Japanese Art in the 1930s], edited by Omuka Toshiharu and Kawata Akihisa, 110-126. Tokyo: Serika Shobō, 2004.

Yamada Kōshun. Ei-Kyū: Hyōden to sakuhin [Ei-Kyū: Critical Biography and Artworks]. Tokyo: Kabushiki Kaisha Seiryūdō, 1976.

Yamada Satoshi. Foto-abangyarudo no dōkō [Tendency of a Photo Avant-Garde]. In Nihon no shūrurearisumu: 1925-1945 [Surrealism in Japan: 1925-1945], edited by Nagoya-shi Bijutsukan, 178-179. Exhibition catalogue. Nagoya: Nihon no Shūrurearisumuten Jikkō linkai, 1990.

Yamada Satoshi. 'Shūrurearisumu kaiga no taidō (1934-1937)' [Awakening of Surrealist Painting (1934-1937)]. In Nihon no shūrurearisumu: 1925-1945 [Surrealism in Japan: 
1925-1945], edited by Nagoya-shi Bijutsukan, 74-75. Exhibition catalogue. Nagoya: Nihon no Shūrurearisumuten Jikkō linkai, 1990.

Yamada Satoshi (ed.). Korekushon Nihon shūrurearisumu 14: Ei-Kyū, Shimozato Yoshio, renzu no avangyarudo [Collection of Surrealism in Japan 14: Ei-Kyū, Shimozato Yoshio, Avant-Garde of the Lens]. Tokyo: Hon no Tomosha, 2001.

Yamaguchi Katsuhiro. " “Jikken Kōbō” to bijutsu no datsu-ryōiki' [Experimental Workshop and the Deterritorialization of Art]. Translator unknown. In Omāju Takiguchi Shūzō ten 11: Jikken Kōbō to Takiguchi Shūzō = Experimental Workshop [Homage Exhibition to Takiguchi Shūzō 11: Jikken Kōbō and Takiguchi Shūzō = Experimental Workshop], edited by Satani Garō, 22-29. Exhibition catalogue. Tokyo: Satani Garō, 1991.

Yamanaka Chirū. 'Atarashii foto korāju' [New Photo-Collage]. In Korekushon Nihon shürurearisumu 6: Yamanaka Chirū, 1930 nendai no oruganaizā [Collection of Surrealism in Japan 6: Yamanaka Chirū, Organiser of the 1930s], edited by Kurosawa Yoshiteru, 419-421. Tokyo: Hon no Tomosha, 1999.

Yamanaka Chirū. 'Berumeeru no ningyō gensō' [The Fantasy of Bellmer's Dolls]. In Korekushon Nihon shūrurearisumu 6: Yamanka Chirū 1930 nendai no oruganaizā [Collection of Surrealism in Japan 6: Yamanaka Chirū, Organiser of the 1930s], edited by Kurosawa Yoshiteru, 442-446. Tokyo: Hon no Tomosha, 1999.

Yamanaka Chirū. 'Buttai no kakumei: Obuje shururearisuto no ichi' [Object Revolution: Position of the Surrealist Object]. In Korekushon Nihon shūrurearisumu 6: Yamanaka Chirū, 1930 nendai no oruganaizā [Collection of Surrealism in Japan 6: Yamanaka Chirū, Organiser of the 1930s], edited by Kurosawa Yoshiteru, 388-395. Tokyo: Hon no Tomosha, 1999.

Yamanaka Chirū. 'Cheko ni okeru futari no gaka' [Two Czech Painters]. In Korekushon Nihon shūrurearisumu 6: Yamanaka Chirū, 1930 nendai no oruganaizā [Collection of Surrealism in Japan 6: Yamanaka Chirū, Organiser of the 1930s], edited by Kurosawa Yoshiteru, 396-398. Tokyo: Hon no Tomosha, 1999.

Yamanaka Chirū. 'Chōgenjitsushugi no taishō' [The Subject of Surrealism]. In Korekushon Nihon shūrurearisumu 6: Yamanaka Chirū, 1930 nendai no oruganaizā [Collection of Surrealism in Japan 6: Yamanaka Chirū, Organiser of the 1930s], edited by Kurosawa Yoshiteru, 416-418. Tokyo: Hon no Tomosha, 1999.

Yamanaka Chirū. 'Chōgenjitsushugi to wa nanika' [What Is Surrealism]. In Korekushon Nihon shūrurearisumu 6: Yamanaka Chirū, 1930 Screen and Layered Depth nendai no oruganaizā [Collection of Surrealism in Japan 6: Yamanaka Chirū, Organiser of the 1930s], edited by Kurosawa Yoshiteru, 402-403. Tokyo: Hon no Tomosha, 1999.

Yamanaka Chirū. 'Furansu kaiga no zen'ei, Sarubadoru Dari no ichi' [French AvantGarde Painting, The Position of Salvador Dali]. In Korekushon Nihon shūrurearisumu 6: Yamanaka Chirū, 1930 nendai no oruganaizā [Collection of Surrealism in Japan 6: Yamanaka Chirū, Organiser of the 1930s], edited by Kurosawa Yoshiteru, 348. Tokyo: Hon no Tomosha, 1999.

Yamanaka Chirū. 'Kaigai Chōgenjitsushugi Sakuhin ten hōkokusho' [Report about the Exhibition of Foreign Surrealist Works]. In Korekushon Nihon shürurearisumu 6: Yamanaka Chirū, 1930 nendai no oruganaizā [Collection Surrealism in Japan 6: Yamanaka Chirū, Organiser of the 1930s], edited by Kurosawa Yoshiteru, 404-405. Tokyo: Hon no Tomosha, 1999.

Yamanaka Chirū. 'OBJET SURRÉALISTE no mondai' [The Problem of the Surrealist Object]. In Korekushon Nihon shūrurearisumu 6: Yamanaka Chirū, 1930 nendai no oruganaizā [Collection of Surrealism in Japan 6: Yamanaka Chirū, Organiser of the 1930s], edited by Kurosawa Yoshiteru, 349-351. Tokyo: Hon no Tomosha, 1999. 
Yamanaka Chirū. 'POCO A POCO, Saikin no gashū no shōkai' [POCO A POCO, Introducing the Recent Illustrated Albums]. In Korekushon Nihon shürurearisumu 6: Yamanaka Chirū, 1930 nendai no oruganaizā [Collection of Surrealism in Japan 6: Yamanaka Chirū, Organiser of the 1930s], edited by Kurosawa Yoshiteru, 399-401 Tokyo: Hon no Tomosha, 1999.

Yamanaka Chirū. 'Sakata Minoru no sakuhin' [Sakata Minoru's Artworks]. Shashin saron, January Edition (1939): 48-51.

Yamanaka Chirū. 'Shashin zōkei zuisō' [Occasional Thoughts on Plastic Photography]. Foto taimusu 17, no. 7 (1940): 60-62.

Yamanaka Chirū. 'Shururearisumu shisō no kokusaika: Kōki ni kaete' [Internationalisation of Surrealist Thought: A Postscript]. In Korekushon Nihon shūrurearisumu 15:

Shūrurearisumu kihon shiryō shūsei [Collection of Surrealism in Japan 15: Surrealism, Collection of Fundamental Documents], edited by Wada Hirofumi, 265-276. Tokyo: Hon no Tomosha, 2001.

Yamanaka Chirū (ed.). L'Échange surréaliste. In Korekushon Nihon shūrurearisumu 15: Shūrurearisumu kihon shiryō shūsei [Collection of Surrealism in Japan 15: Surrealism, Collection of Fundamental Documents], edited by Wada Hirofumi, 175-277. Tokyo: Hon no Tomosha, 2001.

Yamanaka Chirū (trans.). 'Kusatta roba (Saruvadooru Dari)' [Rotting Donkey (Salvador Dali)]. Mizue 394 (1937): 13-17.

Yamamoto Kansuke. 'Garan no densetsu' [Buddhist Legend]. In Korekushon Nihon shūrurearisumu 3: Shūrurearisumu no shashin to hihyō [Collection of Surrealism in Japan 3: Surrealist Photography and Criticism], edited by Takeba Jō, 498-500. Tokyo: Hon no Tomosha, 2001.

Yamamoto Kansuke. 'Shashin ni kansuru kanketsu na zōgon' [A Concise Vilification with Regard to Photography]. In Korekushon Nihon shūrurearisumu 3: Shūrurearisumu no shashin to hihyō [Collection of Surrealism in Japan 3: Surrealist Photography and Criticism], edited by Takeba Jō, 521-524. Tokyo: Hon no Tomosha, 2001.

Yamawaki Iwao. 'Naniga okashii' [ls There Something Funny?]. In Korekushon Nihon shūrurearisumu 3: Shürurearisumu no shashin to hihyō [Collection of Surrealism in Japan 3: Surrealist Photography and Criticism], edited by Takeba Jō, 52. Tokyo: Hon no Tomosha, 2001.

Yamawaki Iwao. 'Nihon no fotomontāju o miru' [Looking at Japanese Photomontage]. In Korekushon Nihon shürurearisumu 3: Shürurearisumu no shashin to hihyō [Collection of Surrealism in Japan 3: Surrealist Photography and Criticism], edited by Takeba Jō, 53-60. Tokyo: Hon no Tomosha, 2001.

Yasui Nakaji. 'Shashin no hattatsu to sono geijutsuteki shosō' [Development of Photography and Its Artistic Aspects]. In Korekushon Nihon shürurearisumu 3: Shürurearisumu no shashin to hihyō [Collection of Surrealism in Japan 3: Surrealist Photography and Criticism], edited by Takeba Jō, 529-539. Tokyo: Hon no Tomosha, 2001.

Yoshihara Jirō, et al. Yoshihara Jirō ten: Seitan 100 nen kinen [Jirō Yoshihara: A Centenary Retrospective]. Exhibition catalogue. Tokyo: Asahi Shinbunsha, 2005.

'Zen'ei shashin saikentō zadankai' [Round Table Meeting Rethinking Avant-Garde Photography]. Kameraman, February Edition (1939): 17-29.

'Zen'ei shashin zadankai' [Avant-Garde Photography Symposium]. Foto taimusu 15, no. 9 (1938): 6-17. 